Rhode Island College

Digital Commons @ RIC

$12-16-2018$

\title{
The Effectiveness of Bispectral Index Monitoring on Intraoperative Awareness in Adult Surgical Patients Undergoing General Anesthesia
}

Eugene D. Lee

Follow this and additional works at: https://digitalcommons.ric.edu/etd

\section{Recommended Citation}

Lee, Eugene D., "The Effectiveness of Bispectral Index Monitoring on Intraoperative Awareness in Adult Surgical Patients Undergoing General Anesthesia" (2018). Master's Theses, Dissertations, Graduate Research and Major Papers Overview. 283.

https://digitalcommons.ric.edu/etd/283

This Major Paper is brought to you for free and open access by the Master's Theses, Dissertations, Graduate Research and Major Papers at Digital Commons @ RIC. It has been accepted for inclusion in Master's Theses, Dissertations, Graduate Research and Major Papers Overview by an authorized administrator of Digital Commons @ RIC. For more information, please contact digitalcommons@ric.edu. 
THE EFFECTIVENESS OF BISPECTRAL INDEX MONITORING ON INTRAOPERATIVE AWARENESS IN ADULT SURGICAL PATIENTS

UNDERGOING GENERAL ANESTHESIA

by

Eugene D. Lee

A Major Paper Submitted in Partial Fulfillment

of the Requirements for the Degree of

Master of Science in Nursing

in

The School of Nursing

Rhode Island College

2018 


\begin{abstract}
Intraoperative awareness (IA), or the unexpected and explicit recall by patients of events that occurred intraoperatively, is a rare but serious event. Incidences of IA have been associated with extreme anxiety, physiologic stress, and the development of posttraumatic stress disorder. Anesthesia has debated the efficacy of brain monitoring devices, such as the Bispectral (BIS) index monitor, to reduce the incidence of IA. By analyzing EEG waves, these monitors can be used to alert the anesthesia provider when the patient may not be sufficiently anesthetized. An integrative review was conducted to evaluate the current evidence on the use of BIS monitoring in reducing IA. The review was comprised of 10 articles which were randomized control trials, prospective studies, literature reviews, and a practice advisory. Articles were critically appraised and a cross analysis comparing similarities and differences was conducted. In the articles reviewed, similarities existed regarding IA patient risk factors and prevention strategies. Anesthesia providers must conduct a thorough preoperative assessment to determine if a patient may be high risk for experiencing IA. Risk factors included: type of surgery, history of IA, opiate or alcohol use, and significant co-morbidities. Prevention strategies included: premedicating patients with an amnestic such as a benzodiazepine and discussing the possibility of IA with high-risk patients. Findings of this review indicated BIS monitoring may serve as a useful adjunct monitoring tool but should not be utilized as a primary source in determining a patient's anesthetic. Evidence does not support BIS monitoring as a means of preventing IA.
\end{abstract}




\section{Acknowledgements}

I want to thank my supportive wife and daughter for being able to put up with me over these exhausting 2.5 years! 


\section{Table of Contents}

Background/Statement of the Problem .................................................................. 1

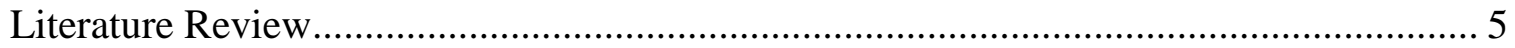

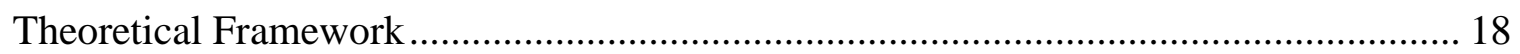

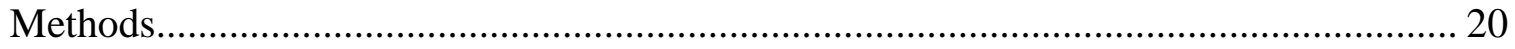

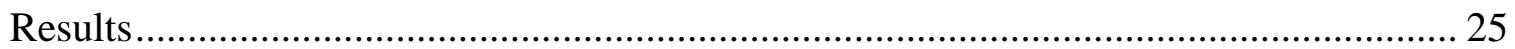

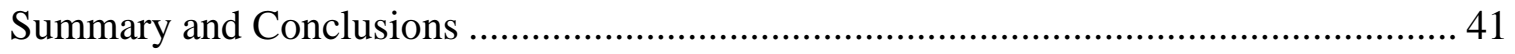

Recommendations and Implications for Advanced Nursing Practice ........................... 45

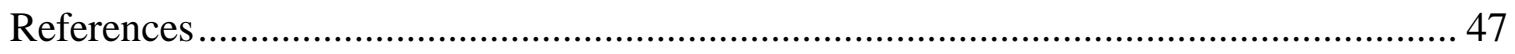

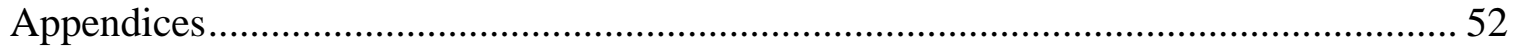


The Effectiveness Of Bispectral Index Monitoring On Intraoperative Awareness In Adult Surgical Patients Undergoing General Anesthesia

\section{Background/Statement of the Problem}

The advancement of surgery was hindered by a lack of comprehension of disease pathophysiology, patient anatomy, and infection control, but most importantly, a scarcity of dependable and safe anesthetic practices (Buttenworth, Mackey, \& Wasnick, 2013). Although ancient civilizations used opium poppy, coca leaves, and other substances for medical purposes, effective anesthesia would not be utilized until centuries later.

The first public demonstration of anesthesia was introduced in 1846, by dentist William Morton when he used ether for a surgical operation. Prior to anesthesia, surgical procedures were vastly limited because of patient agony and the inability to have a painless operation. Nitrous oxide and chloroform were also used to varying degrees during this time period. Nitrous oxide was first used for dental extractions in 1844, although it was not potent enough for surgical procedures (Buttenworth et al., 2013). Chloroform was first used for labor analgesia in 1847. Ether was actually the customary inhaled anesthetic until the 1960s, when nonflammable fluorinated hydrocarbons were developed (Buttenworth et al., 2013). Although most of these substances are no longer commonly used, they were essentially the forbearers of today's two major inhaled anesthetics, sevoflurane and desflurane, which were developed and improved upon from these previous inhaled anesthetic agents.

Anesthesia has progressed to a significant extent. It is a critical aspect of surgery and addresses most, if not all of the following: reversible loss of consciousness, 
analgesia, amnesia, and some level of muscle relaxation; however, there are still instances where a patient has intraoperative awareness (IA) (Butterworth et al., 2013)

Bispectral index monitoring (BIS) is a monitoring system that is used by some institutions intraoperatively, which allows anesthesia practitioners to have real-time measurements of a patient's EEG signals. It is intended as a tool to guide practitioners in determining a patient's depth of anesthesia. It is often used in critical care areas when patients have received neuromuscular blockers and sedatives to gauge a patient's depth of sedation. BIS values range from 100 , which is correlated with an awake patient, to 0 , which indicates no electrical brain activity. It is typically thought that intraoperatively targeting a range of 40-60 on this continuum allows for reduced patient awareness while simultaneously enabling practitioners to titrate anesthesia medications (Nagelhout \& Plaus, 2014). Being able to successfully reduce anesthetic use while preventing patient awareness facilitates faster patient emergence from anesthesia, decreased post-anesthesia care unit (PACU) times, hospital lengths of stay, and increased operating room (OR) turnover due to shorter procedure times.

Although patient monitors such as electrocardiogram (ECG), pulse oximetry, blood pressure (BP), and end-tidal carbon dioxide (EtCO2) monitoring are routinely used in all ORs across the country, BIS is not routinely used. The American Association of Nurse Anesthetists (AANA) addresses neuromuscular appraisal in its $5^{\text {th }}$ Standard of Practice stating, "When neuromuscular blocking agents are administered, monitor neuromuscular response to assess depth of blockage and degree of recovery” (AANA, 2013, p.2). This monitoring usually entails a peripheral nerve stimulator, which is a small box-like device capable of producing a low electrical current over the path of the 
patient's ulnar or facial nerve by means of electrodes. This enables the practitioner to measure the patient's physical response to the neuromuscular blocking agent. While this allows for a neuromuscular depth analysis, this is not a measurement of patient awareness, and the AANA does not directly address BIS or awareness in its standards of practice. The AANA acknowledges that although rare, the experience of IA can be extremely distressing to the extent that post-operative anxiety ensues and behavioral counseling may be required (AANA, 2009).

General anesthesia is described as the condition of loss of consciousness where a patient does not react to painful stimuli such as surgical incisions (Kotsovolis \& Komminos, 2009). One of the main benefits of intravenous and inhaled anesthetics is their ability to cause amnesia at dosages that are significantly lower than their doses to induce unconsciousness (Nagelhout \& Plaus, 2014). However, there are cases where although the patient may not physically react to an incision, they may have memories of the events occurring after induction and before emergence, known as IA. Although not a common occurrence, studies have demonstrated awareness occurring in $0.15 \%$ of surgeries (Mashour et al., 2012). The larger issue, according to Kotsovolis and Komminos (2009), is that IA can be serious enough to lead to post-traumatic stress disorder (PTSD) and result in potential litigation against the practicing anesthesia provider and/or healthcare system. Many anesthesia providers will rarely encounter IA and may not have a definitive comprehension of what the patient experiences when it does occur (Avidan \& Sleigh, 2014). Furthermore, because of the relatively low incidence rate of IA, Avidan and Sleigh (2014) concluded that spending time to learn more about preventative methods is not an efficient use of clinicians' time, and that 
alternative techniques should be developed. BIS is one of these alternative techniques and has been used to monitor IA.

Therefore, the purpose of this paper is to conduct an integrative review to examine the effectiveness of BIS monitoring on IA in adult surgical patients undergoing general anesthesia.

Next, the literature review will be presented. 


\section{Literature Review}

\section{Anesthesia}

In 1846, Oliver Wendell Holmes defined anesthesia as the state that encompasses amnesia, analgesia, and narcosis (Buttenworth et al., 2013). That same year, William Morton performed a surgical procedure utilizing inhaled ether in the first publicized demonstration of general anesthesia (Buttenworth et al., 2013). Prior to 1846 and before the discovery of subsequent anesthetic agents, surgical procedures were not advancing because of the shortage of dependable and safe anesthetic techniques. Inhalational agents have continued to be developed over time. The two most popular agents currently used in developed countries, desflurane and sevoflurane, have only been utilized in practice since the 1990s.

Advances in anesthesia have allowed surgical procedures to encompass the entire lifespan, including patients with multifaceted comorbidities. At the same time, surgical outcomes have improved as a result of enhanced technology and monitoring techniques, while anesthesiology quickly embraced evidence-based research and translated findings into practice and specialty society guidelines (Miller et al., 2015).

It is important to discern the difference between the frequently used anesthesia terms: awareness, anesthesia, and sedation. Awareness is described as both consciousness and memory. Wakefulness is the state of being arousable, which can occur during sleep-wake cycles as well as vegetative states or unconsciousness (Miller et al., 2015). Therefore, one can be awake without actually being aware. There are also levels of consciousness that are disparate. Levels of consciousness include alertness, drowsy, and anesthetized (Miller et al., 2015). Anesthesia was first defined by Oliver 
Wendell Holmes, as the state that combines amnesia, analgesia, and narcosis to make painless surgery possible. Sedation is defined as a 4-level continuum along which awareness and anesthesia are integrated (Nagelhout \& Plaus, 2014).

The first level of sedation is minimal sedation (formerly anxiolysis) where patients are still able to respond normally to verbal commands. There may be some impaired cognitive ability, but cardiovascular and respiratory functions remain normal. The second level is moderate sedation, formerly conscious sedation, where patients have a depressed consciousness but can still respond appropriately to verbal commands, either alone or with simultaneous light tactile stimulation. Airways remain patent and respiratory and cardiovascular functions typically are maintained. The third level is a deep sedation where patients are not easily aroused but can still respond purposefully after repeated or painful stimulation. In this level, airways might need management along with ventilation, although cardiovascular function is usually maintained. The fourth level is anesthesia (general anesthesia) where patients undergo a drug-induced loss of consciousness and are not arousable even to painful stimulation such as an incision. Independent ventilation and airway management are often compromised, and positive pressure ventilation will be required either because of the depressed respiratory function or the use of neuromuscular blockers. Cardiovascular function may also be diminished (Nagelhout \& Plaus, 2014).

Although all anesthetic medications have recommended dose ranges, there are unique patient characteristics that are pertinent to these ranges. Patient characteristics include: age; body habitus; gender; previous use/nonuse of opioids, benzodiazepines, alcohol; existing heart, lung, kidney, and liver disease; dehydration; and blood loss 
(Miller et al., 2015). Anesthesia medication effects and durations can vary widely among patients, therefore it is the practitioner's responsibility to interpret patient responses and react accordingly during anesthesia delivery.

\section{Intraoperative Awareness}

Intraoperative awareness occurs when a patient has undergone general anesthesia and becomes conscious during the procedure, then consequently form memories, or has recall of events that occurred during the surgical procedure (Apfelbaum et al., 2006). Intraoperative awareness is not a frequent occurrence but studies have reported it can be severe enough to cause PTSD (Leslie, Chan, Myles, Forbes, \& McCulloch, 2010). Additionally, although awareness does not always cause PTSD, the immediate emotional anguish along with the knowledge of being paralyzed are significant risk factors for developing PTSD (Nagelhout \& Plaus, 2014). As previously mentioned, amnesia is one of the goals of general anesthesia and the idea of awareness during a surgical procedure can be severely distressing to a patient. Patients who are aware and have recall of these events report extreme feelings ranging from panic attacks to oncoming death. Intraoperative awareness can contribute to problems sleeping, depression, and possibly avoiding hospitals in the future (Sullivan, 2016).

The American Psychiatric Association (APA, 2017) states that PTSD is characterized by recollections of the event, evasion of stimuli that are associated with the event, negative memories and moods from the event, and an intensified reactivity to potential threats. Additionally, some studies have found that as many as $70 \%$ of patients that experience IA will eventually suffer from symptoms of PTSD (Leslie et al., 2010). Fortunately, IA under general anesthesia is a rare occurrence, only occurring about one to 
two times per 1,000 patients in the US (Sullivan, 2016). Even though this occurrence rate may seem non-significant, over 20 million anesthetics are administered in the US per year, which would lead to about 26,000 cases of IA (Sebel et al., 2004).

Awareness is described as having four separate phases. These phases are conscious awareness with and without explicit recall, subconscious awareness with implicit recall, and a lack of awareness or recall (Sullivan, 2016). From an anesthesia standpoint, explicit recall is the biggest concern as this would be the condition that could eventually lead to PTSD. Many patients claim explicit recall is the cause of a terrible hospital experience (Sullivan, 2016).

Intraoperative awareness cannot be detected intraoperatively as most patients are either sedated, intubated, paralyzed, anesthetized, or a combination of the above. This prompted the American Society of Anesthesiologists (ASA) to acknowledge that IA is something that cannot be measured intraoperatively and can only be recognized postoperatively by questioning the patient (Apfelbaum et al., 2006). However, the ASA did conclude that brain activity monitors should be used for patients that have certain risk factors for IA or with certain types of procedures (Apfelbaum et al., 2006).

\section{Risk Factors for Intraoperative Awareness}

Besides a patient having a prior incident of IA, IA can be difficult to predict. The following risk factors for IA have been identified in the literature: history of IA, substance use, patients with chronic pain on high doses of opioids, history of or anticipated difficult intubation, patients with significant uncontrolled comorbidities, ASA classification four or five (American Society of Anesthesiologists Patient Classification System where four is someone with a severe systemic disease which is a constant threat 
to life and five is a moribund person who is not expected to survive without the proposed surgery), patients with restricted hemodynamic reserve; cardiac, trauma, or emergency surgery, C-section; planned use of muscle relaxants during the maintenance phase, total intravenous anesthesia (TIVA), $\mathrm{N}_{2} \mathrm{O}$-opioid anesthesia, or decreased anesthesia doses during paralysis (Gelfand, Gabriel, Gimlick, Beutler \& Urman, 2017). In addition, anesthesia equipment malfunction can be another factor contributing to IA if it prevents the patient from receiving the required amounts of anesthetics (Kotsovolis \& Komminos, 2009). Other risk factors can include hypovolemia, female sex, young or pediatric patients, and certain medications such as neuromuscular blockers, which cause paralysis and can prevent physiological signs of IA (Castellon-Larios, Rosero, Nino-de Mejia, \& Bergese, 2016). Due to so many possible risk factors, it remains difficult to predict which patients are most likely to experience IA.

Although IA was previously mentioned as occurring between $0.1-0.2 \%$ among all surgical patients, for those at high risk, this rate can increase to as much as $1 \%$ (Avidan et al., 2008). Intraoperative awareness is a serious enough event, that The Joint Commission (TJC) and the ASA have addressed this issue to try and increase provider awareness of the condition and prevent it from occurring. Patients have displayed recall and anxiety even when exposed to items such as blue or green colors (colors of most surgical team scrubs), television shows revolving around hospitals, or just smelling alcohol (Kotsovolis \& Komminos, 2009). In addition, merely being asked to go to a hospital for an interview, two-thirds of patients who experienced IA had signs of panic and refused to go to the hospital (Kotsovolis \& Komminos, 2009). 
Some of the difficulties in detecting IA is that there is a fair amount of subjectivity involved and patients might have some memory of events, but not necessarily definitive recall (Forman, 2006). The literature indicates that confirmed awareness can only be achieved if patients can actually recall music or conversations that occurred during the procedure (Forman, 2006). In addition, patients might not actually realize it until weeks or months following the surgical procedure that they experienced IA. Lastly, some patients are unwilling to acknowledge in the immediate post-operative period they experienced IA because they are still reliant on hospital personnel and do not want to compromise their care (Forman, 2006).

\section{Bispectral Index Monitoring}

According to the manufacturer, the BIS index is calculated using a combination of electroencephalogram (EEG) signal processing techniques including bispectral analysis, power spectral analysis, and time domain analysis (Kelley, 2012). An EEG indicates a level of metabolic activity within the brain. Electrical brain activity requires the use of oxygen, glucose, and cerebral blood flow and if there are reductions in these physiologic mechanisms, EEG activity can be depressed (Nagelhout \& Plaus, 2014). The BIS monitor is an instrument, which processes EEG signals and waveforms through an algorithm to generate a single number, which fluctuates based on the level of consciousness of the patient (Kelley, 2012). The algorithm analyzes activity within the EEG and can change based on the level of anesthesia active in the brain. This brain activity includes high-frequency activation, low-frequency synchronization, nearly suppressed periods, and fully suppressed periods, and when combined, generate the BIS index (Kelley, 2012). 
The BIS index produces a number between 0 and 100, where 100 represents a fully awake patient and a 0 depicts an isoelectric EEG, which correlates with a comatose patient (slowed and dampened brain activity). It is also important to remember that this scale exists on the consciousness continuum (unitless numbers) with the following correlations: 100- fully awake, 80- light/moderate sedation, 60- general anesthesia, 40deep hypnotic state, 20- burst suppression, and 0- isoelectric or flatline EEG (Kelley, 2012). An isoelectric or flatline EEG is usually associated with brain death. In terms of intraoperative recall, the literature indicates a level of 60 will produce a low potential for explicit recall, and generally, a range of 40 or 45-60 is typically targeted for anesthesia (Kelley, 2012). Although there are many different medications and techniques (volatile inhaled gases or intravenous inducing agents) utilized to produce an anesthetized level of consciousness, the generated BIS value is similar for all methods except when halothane or ketamine are used (Kelley, 2012). One last aspect that must be considered is although the BIS may appear to be real-time, the displayed value is based on data recorded over the previous 15-30 seconds and the value may be delayed by five to ten seconds compared to a detected clinical change (Kelley, 2012). Sudden changes in BIS levels should be examined for causes such as possible artifact, functional anesthetic delivery systems, sufficient anesthetic dosing, and current levels of patient surgical stimulation (Kelley, 2012).

\section{Bispectral Index Monitoring and Intraoperative Awareness}

Numerous studies have investigated the connection between BIS monitoring and IA. A prospective study conducted by Ekman, Lindholm, Lenmarken, and Sandin (2004) found a $77 \%$ decrease in awareness when BIS monitoring is used compared to a historical 
group of participants who did not have BIS awareness monitoring. This study analyzed a group of 4,945 patients who had surgery requiring muscle relaxants and/or intubation utilizing BIS and a historical group of 7,826 patients who also needed muscle relaxants and/or intubation but without any cerebral monitoring. Two patients in the BIS group had awareness during intubation when their recorded BIS values were $>60$. In the nonBIS group, there were 14 cases of participants who experienced IA. This was a statistically significant result ( $p=0.019$ single sided and $p=0.038$ double sided) and the authors concluded for general anesthesia cases requiring intubation and/or muscle relaxants, the use of BIS correlated with a decreased incidence of awareness (Ekman et al., 2004).

Myles, Leslie, McNeil, Forbes, and Chan (2004) reported similar results in their study titled “The B-Aware Randomized Control Trial”. This was a prospective, randomized, double-blind multi-center trial involving 2,463 patients who were at highrisk of IA. There were 1,225 patients in the BIS group and 1,238 in the control group with IA occurrences of 2 and 11, respectively. The authors reported BIS reduced the risk of IA in surgical patients undergoing general anesthesia. In addition, Myles et al. (2004) reported an $82 \%$ reduced risk of awareness in high-risk patients utilizing the BIS monitor.

Castellon-Larios et al. (2016) conducted a non-systematic review and analyzed over 68 studies between 2001 and 2015 involving BIS and IA. The authors concluded that BIS can help prevent IA and the most frequent causes of IA were: under dosing of anesthetics (which could be related to a patient's resistance to anesthesia, age, tobacco use, obesity, chronic use of alcohol, opioids, and amphetamines), mechanical problems (which could involve the anesthesia machine or IV issues), and patients with a low 
physiologic reserve and low anesthetic requirements. In addition, Castellon-Larios et al. (2016) proposed strategies to reduce IA which include: sufficiently pre-medicate patients prior to their procedures with agents that cause amnesia (such as benzodiazepines); adequately anesthetize patients at induction, intubation, and prior to initial incision; judiciously dose neuromuscular blockers; maintain a minimum alveolar concentration (MAC) of 0.7 and higher when using inhaled volatile agents during general anesthesia; in obstetric, trauma, or difficult intubation patients, contemplate utilizing opioids and amnesic medications.

Additional studies have produced contrary results. O’Connor et al. (2001) concluded there is no evidence that BIS actually lowers the risk of IA. Because of the rarity of IA (1 in 20,000), the authors completed a power analysis and determined that it would take a very large study, consisting of 200,000-800,000 participants, to adequately ascertain if BIS reduced IA to a significant extent using an $80 \%$ power. Obviously, this size study would be unfeasible to conduct. Furthermore, since existing studies have already included reported cases of IA (even while using BIS), it is certain that the effectiveness of BIS is less than 100\% (O’Connor et al., 2001). As a result, along with the associated cost of conducting such a large-scale study, the authors concluded that using BIS to reduce the risk of IA is unproven (O'Connor et al., 2001).

Several case studies have been reported of patients experiencing IA. One example discussed in the literature is the case of a female patient who reported being awake during an abdominal procedure. The patient described hearing voices as well as feeling the surgical procedure, although admitted experiencing no pain. The patient had a BIS value maintained at 40 and yet claimed she had been awake (Kurehara, Horiuch, 
Takahash, Kitaguchi, \& Furuya, 2001). The patient had been intubated using propofol, fentanyl, and vecuronium. She was anesthetized for the procedure with a propofol infusion and a thoracic epidural infusion with lidocaine (for analgesia). Kurehara et al. (2001) concluded that although BIS has some value as an indicator for a hypnotic state, occurrences of IA can still exist, even when the BIS value would indicate that a patient should be sufficiently anesthetized (Kurehara et al., 2001).

It is debatable if the BIS index produces better results than end-tidal anesthetic concentration (ETAC), which is a mandatory parameter that is monitored for any inhaled anesthetic for general anesthesia (Stein \& Glick, 2016). Several studies have directly compared BIS with ETAC, and the results have generally been similar (Avidan et al., 2008; Avidan et al., 2011; Mashour et al., 2012). Avidan et al. (2008) conducted a study where they randomly placed 967 and 974 high-risk patients in a BIS guided and end-tidal anesthetic gas (ETAG) group, respectively. This study reported two cases of definite IA in each of the groups. Avidan et al. (2011) published an additional study in which 2,861 and 2,852 participants were placed in a BIS guided and ETAG group, respectively. In this study, 7 patients in the BIS group experienced definite IA compared with only 2 in the ETAG group. Furthermore, there were 19 cases of possible IA in the BIS group and just 8 in the ETAG group. In both of these studies, Avidan et al. $(2008,2011)$ utilized a panel of three experts to review patient answers and classified them as: definite IA, possible IA, or did not experience IA. A consensus of the three experts was needed in order for a patient to be placed in one of the three groups. If consensus could not be reached, a fourth expert would make the determination. 
Mashour et al. (2012) conducted a larger-scale study in which they reported 11 cases of IA out of 9,376 patients in the ETAG group, and eight cases of IA out of 9,460 patients in the BIS group. This was not a statistically significant $(p=0.48)$ reduction in IA, and actually prompted the authors to cease the study due to futility.

\section{Depth of Anesthesia and BIS}

A BIS level of 40 indicates a deep hypnotic state. Most patients who achieved a BIS of 40 would be considered to be “deep” enough (sufficiently anesthetized) in terms of anesthesia as noted by the manufacturer. If a patient is considered "light" (or not sufficiently anesthetized), they would be at risk for IA, movement during the procedure, and possibly acute injury. Anesthesia is a never-ending balancing act with a constant focus on maintaining a patient from being too “deep" (overly anesthetized) or too "light” (under anesthetized). A patient needs to be anesthetized enough so that their sympathetic nervous system is suppressed so that they are not moving during the procedure but not too anesthetized which could contribute to negative hemodynamic effects and poor patient outcomes.

Lindholm et al. (2009) reported a statistical connection between the length of deep anesthesia (defined as the amount of time with a BIS <45) and one and two-year mortality in patients with significant disease or malignancies. The original study was performed to examine the effect of BIS monitoring on IA, but the authors used some of the additional data to conduct this study. Lindholm et al. (2009) found that when preexisting malignancy was not used as a co-variate in their analysis, the length of deep anesthesia was a significant indicator in one and two-year mortality; however, when preexisting malignancy was used as a co-variate, the same statistical significance was not 
realized. The authors concluded that a randomized trial would need to be performed to truly demonstrate any cause and effect from deep anesthesia, but also acknowledged that ASA status, current malignancy level at surgery, and age were critical factors in determining mortality.

In order for a sedation monitor to be effective, it must be able to produce significantly discrete values for different levels of sedation without any overlap. Additionally, the anesthetic given should not have an effect on the values that distinguish each sedation level (Ibrahim, Taraday, \& Kharasch, 2001). Ibrahim et al. (2001) reported that the range of BIS values for patients who responded to voice overlapped with BIS values of those who did not respond to voice. The authors also found some patients that had very high BIS scores (normally indicative of wide-awake patients) were deeply sedated and some patients who were wide awake had very low BIS scores (normally indicative of moderate to deeply sedated patients). Ibrahim et al. (2001) reported that the choice of anesthetic medication played a role in the BIS score. For example, patients that received sevoflurane or propofol would often have an average BIS below 60, while other patients that received midazolam would never have a BIS value of less than 65 (Ibrahim et al., 2001). This study was looking at average sedation between the three study medications and BIS values and found that there was wide variability among the BIS values. Therefore, this made it difficult to assess the depth of sedation and derive any recommendations (Ibrahim et al., 2001).

Monk and Weldon (2011) conducted a review of retrospective and randomized control trials comparing BIS to ETAC monitoring. Results were very similar but somewhat better for ETAC monitoring in terms of post-operative outcomes and cost, but 
both were similar in terms of patient awareness. Monk and Weldon (2011) concluded that there is no definitive consensus on the advantage of using BIS compared to ETAC monitoring to prevent IA. The authors also concluded that BIS levels of less than 45 were associated with increased patient mortality, but that this relationship could be an epiphenomenon and not necessarily a cause and effect. Additionally, Monk and Weldon (2011) noted that anesthesia providers do not typically monitor patients longer than a day or two post-operatively and therefore do not often encounter IA, as it can be reported days to weeks following the surgery.

Based upon this literature review, there does not appear to be a clear consensus on the effectiveness of BIS monitoring. While BIS monitoring certainly has shown to have some value to an anesthesia provider as another clinical indicator, it should not override other critical indicators such as heart rate, blood pressure, respiratory rate, or end-tidal anesthetic concentration.

Next the theoretical framework will be discussed. 


\section{Theoretical Framework}

The theoretical framework used to guide this integrative review is Betty Neuman’s Health Care Systems Model. This model focuses on using primary, secondary, and tertiary prevention as a key component towards the goal of patient stability. Primary prevention occurs before the stressor invades the system and it focuses on averting stress and decreasing risk factors (Gonzalo, 2011). Secondary prevention occurs after the system reacts to the invading stressor and hopefully is able to bring the system back to homeostasis (Gonzalo, 2011). Tertiary prevention occurs after secondary prevention and is aimed at maintaining wellness after system stability has occurred (Figure 1) (Gonzalo, 2011). 


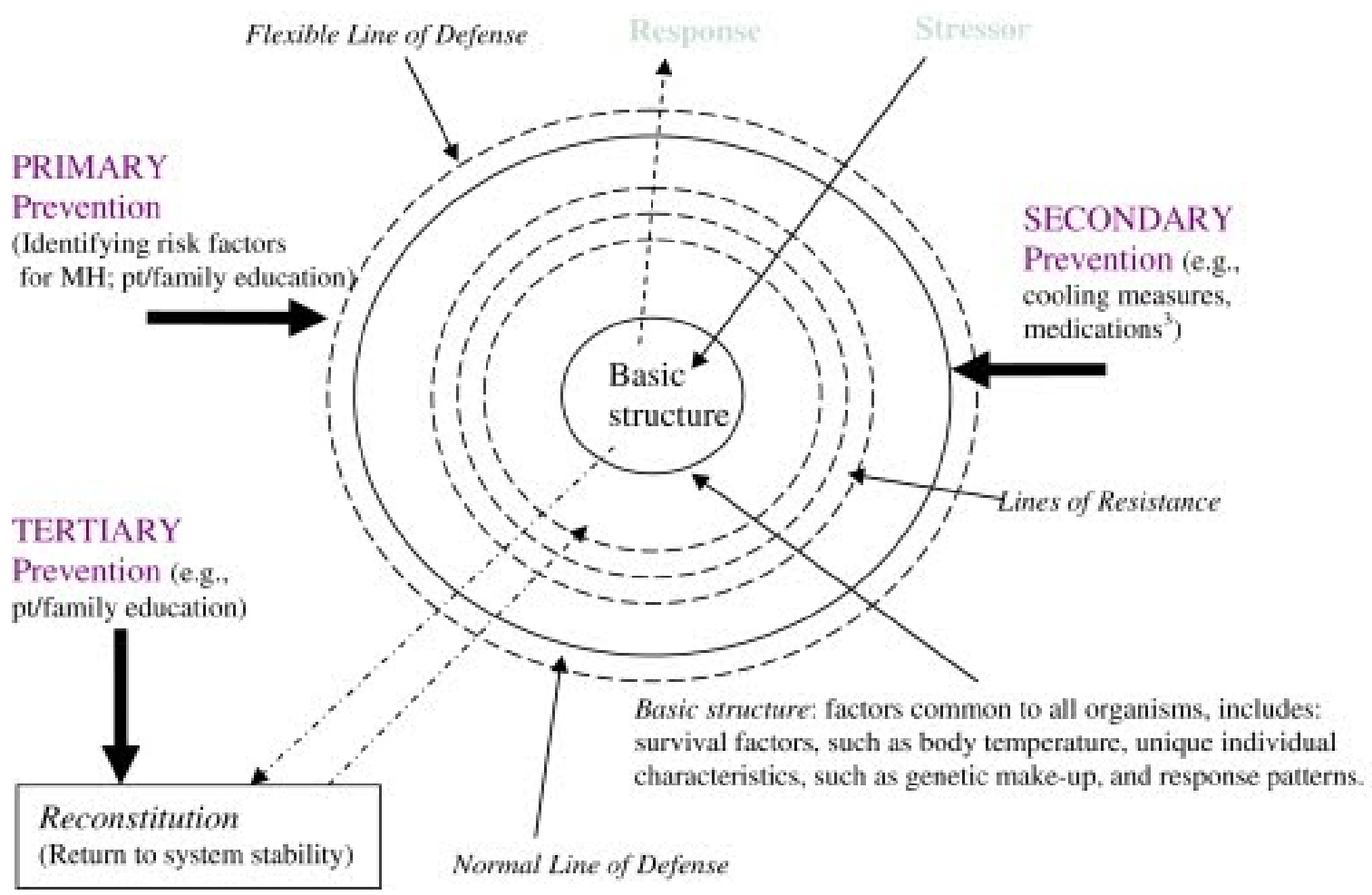

Figure 1. The Neuman Systems Model. Adapted from "Scientific Advances in the Genetic Understanding and Diagnosis of Malignant Hyperthermia” (Hernandez, Seacrest, Hill, \& McClarty, 2009).

Betty Neuman’s Health Care Systems Model conceptualizes client wholeness and the goal of ideal health through prevention strategies. It examines how patients react to stressors from the environment and these stressors have the potential to disrupt the client's well-being. Intraoperative awareness is a potential primary patient stressor, and therefore preventing this phenomenon can lead to improved patient outcomes. Identifying risk factors and prevention is one of the major focuses of this model and the BIS monitor's main use is preventing awareness and assisting anesthesia providers in determining sedation levels in patients. 


\section{Methods}

An integrative review examines research that has been completed and attempts to formulate conclusions based on the literature (Schneider, Whitehead, LoBiondo-Wood, \& Haber, 2012). The major strength of an integrative review is that it allows a blend of various types of research and literature including randomized control trials, observational studies, qualitative studies, literature reviews and expert opinions to be examined together with the goal of formulating evidence-based practice recommendations. Therefore, the purpose of this paper was to conduct an integrative review to examine BIS monitoring on IA in adult surgical patients undergoing general anesthesia.

\section{Inclusion/Exclusion Criteria}

Inclusion criteria included literature published in the English language after the year 2000, general anesthesia patients, literature that included patients age 16 years or older, and literature that analyzed IA or had outcomes that were investigating IA in patients. Exclusion criteria included literature that included patients under the age of 16, used sedation and not general anesthesia, and not published in the English language.

\section{Search Strategy}

The review was comprised of literature found using keyword searches in CINAHL, Medline, and PubMed databases. Keywords utilized included BIS, bispectral index monitoring, intraoperative awareness, general anesthesia, and prevention of awareness.

The PRISMA (Preferred Reporting Items for Systematic Reviews and MetaAnalyses) flow diagram (Figure 2) was used to select articles that were included in this review. Although PRISMA was originally intended to assist researchers advance how 
systematic reviews and meta-analyses were conveyed, it can be used for other types of research as well (Moher, Liberati, Tetzlaff, \& Altman, 2009). For this review, the flow diagram was utilized and after duplicates were removed, the articles were screened by title and abstract to determine if they met inclusion and exclusion criteria. Those that seemed potentially suitable were then read in entirety to assess the suitability of inclusion in this review. Appendix A displays the completed PRISMA flow diagram for this integrative review. 


\section{PRISMA 2009 Flow Diagram}

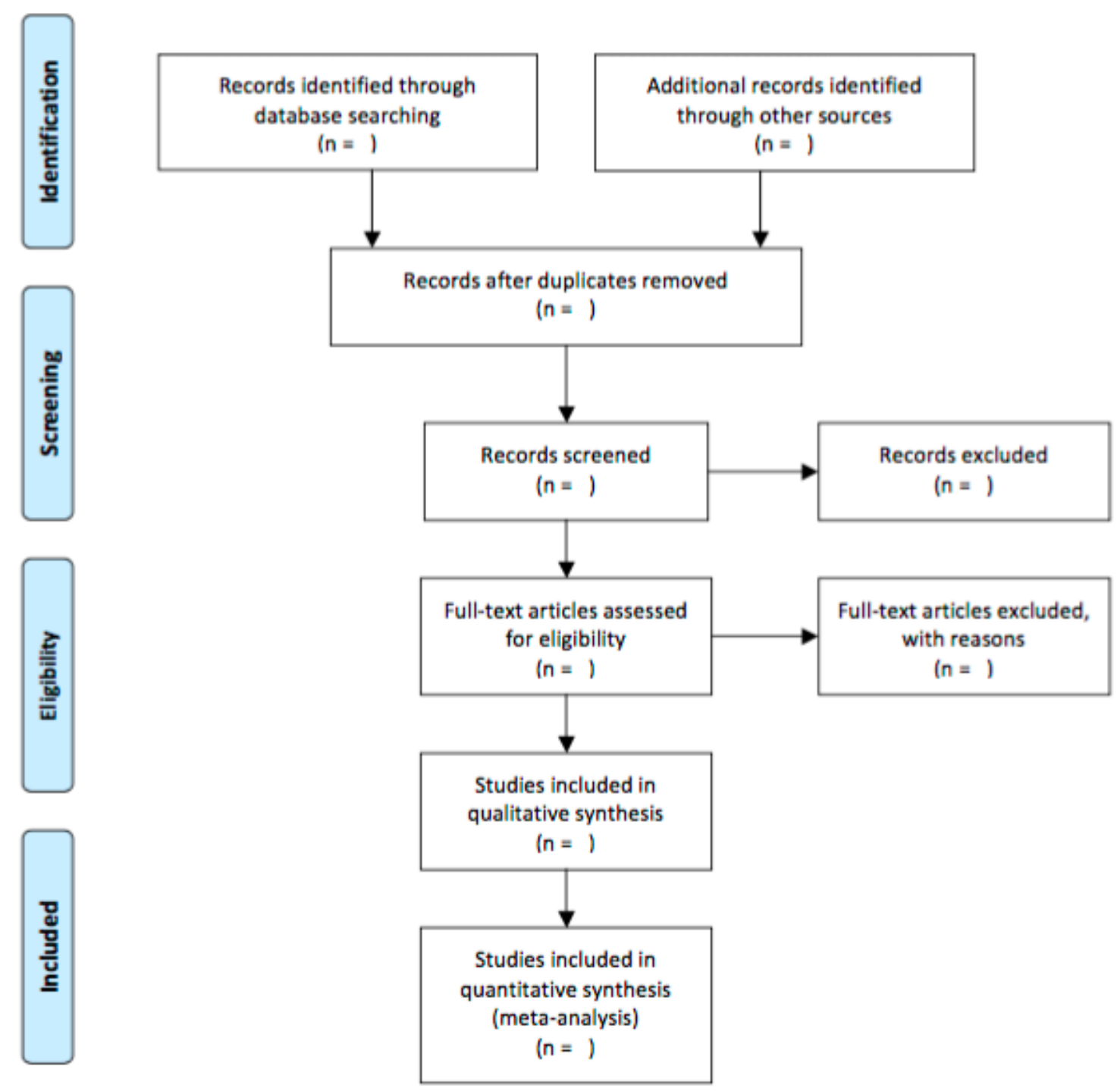

Figure 2. Adapted from “PRISMA 2009 Flow Diagram” by Moher D, Liberati A, Tetzlaff J, Altman DG, The PRISMA Group (2009). 


\section{Data Collection}

Literature that met the inclusion criteria were presented in table and narrative format. A data collection table was created by the author and was designed to include information about each article’s purpose, design, sample, methods, data analysis, results and limitations (Table 1).

Table 1

\begin{tabular}{|l|l|l|l|l|l|l|}
\hline Purpose & Design & Sample & Methods & $\begin{array}{c}\text { Data } \\
\text { Analysis }\end{array}$ & Results & Limitations \\
\hline & & & & & & \\
\hline
\end{tabular}

\section{Critical Appraisal}

Articles were critiqued in detail using Polit and Beck’s (2017) guide to help determine the overall strength of the study in question. The research critique tables from Polit and Beck allow articles to be examined closely and determine how convincing the findings are from a clinical and/or evidence-based practice standpoint. Critique of the articles included study limitations, existence of bias, data collection methods, statistical analyses, research reliability and validity, generalizability, clinical application and several other aspects. Completion of these tables gives a credible gauge as to the quality of the studies.

\section{Cross Study Analysis}

Literature included in this integrative review was evaluated and the similarities and differences were compared. A cross analysis table was developed by this author in order to examine the effectiveness of bispectral index monitoring on IA in adult surgical patients undergoing general anesthesia (Table 2). 
Table 2

\begin{tabular}{|l|l|l|l|l|}
\hline Author, & Design & BIS & IA & Patient specific risk \\
Year & & Monitoring & & factors \\
\hline & & & & \\
\hline
\end{tabular}

Next, the results will be discussed. 


\section{Results}

The PRISMA flow diagram illustrates how studies were selected for this integrative review (Appendix A). As described previously, keywords searched in PubMed, CINAHL, and Medline comprised the initial search. An initial search yielded 665 articles. After duplicates were removed, as well as literature that did not have a focus on IA, 301 articles were then screened in-depth to determine their eligibility and 200 were further excluded. Finally, 91 articles were excluded from this review for reasons of not using general anesthesia, using BIS for sedation monitoring, procedures that were not true surgeries such as colonoscopies, and other related reasons. A final combination of 10 articles composed of randomized control trials, prospective studies, literature reviews, and a practice advisory were used to comprise this integrative review.

\section{Data Collection Results}

Ekman et al. (2004) conducted a prospective non-randomized experimental study, with patients who required muscle relaxants and/or intubation, and compared the incidence of IA (explicit recall) between two groups. Only one group was monitored using BIS. There were 4,945 participants in the BIS group and 7,826 participants in the non-monitored BIS group. Participants were interviewed before they were discharged from the post anesthesia care unit, one to three days later, and seven to fourteen days after their surgery. However, this can be considered a limitation in this study as IA can sometimes not be apparent to weeks or months later. Ekman et al. (2004) reported two participants experienced IA in the BIS monitored group while the non-monitored group had 14 participant IA experiences and these findings were statistically significant $(p=$ 0.00001). Additionally, the two cases of IA both had BIS values of greater than 60 at the 
time of awareness. Ekman et al. (2004) proposed that differentiating between actual IA and other memories can be difficult to distinguish. The authors acknowledged that 20 participants were further investigated after their Brice interview due to some experiencing possible awareness, although only two ended up being cases of actual awareness. The Brice interview is composed of five questions that can assist in the diagnosis of a possible occurrence of IA (Kotsovolis \& Komminos, 2009). The authors concluded that the use of BIS during general anesthesia where intubation and/or muscle relaxation is required reduces the incidence of IA (Appendix B, Table B1).

Avidan et al. (2008) performed a single-center prospective non-randomized study to determine if the use of BIS is superior over ETAG in preventing IA in high-risk patients. The BIS and ETAG groups consisted of 967 and 974 participants, respectively. The BIS group had a target range of 40-60 while the ETAG group had a target of $0.7-1.3$ MAC. Interviews using the Brice questionnaire were conducted within 24 hours of extubation, at one to three days, and then again at thirty days. There were only two cases of IA in each group and no statistically significant differences. The authors concluded that BIS monitoring cannot reliably prevent IA and anesthesia providers may have a false sense of security when utilizing it (Appendix B, Table B2).

Sebel et al. (2004) conducted a prospective, non-randomized, descriptive cohort study to determine the rate of IA during general anesthesia. The study was instituted at seven medical centers and use of the BIS monitor was at the anesthesiologist's discretion. The BIS monitored group consisted of 7,364 participants and the non-monitored group consisted of 11,723. Use of the BIS monitor varied widely across the seven sites from $0 \%$ to $74 \%$. The results showed that out of all the patients, there were 25 episodes of 
awareness, 46 episodes of possible awareness, and 1,183 episodes of possible intraoperative dreaming. In the BIS monitored group, there were 13 cases of awareness compared to 12 episodes of awareness in the group without BIS monitoring. Sebel et al. (2004) noted that among the BIS IA patients, a number of them did have BIS values greater than 60 . Furthermore, the authors acknowledged that this study was not designed to test the effectiveness of the BIS monitor due to the lack of randomization and lack of a protocol (Appendix B, Table B3).

Myles et al. (2004) conducted a prospective, randomized, double blind multicenter trial. The purpose of this study was to examine whether BIS would decrease the occurrence rate of IA during surgery in high-risk adults. The BIS group included 1,225 participants and the control group included 1,238 participants. The protocol was to maintain a BIS level of 40-60 from the start of intubation to closing the incision. Interviews to detect IA occurred at two to six hours, between one and one and a half days, and thirty days after surgery. In the BIS group, 22 patients experienced possible or definite IA while 27 experienced IA in the control group. Myles et al. (2004) concluded that BIS monitoring is statistically effective $(p=0.022)$ in decreasing the incidence of IA in high-risk patients undergoing general anesthesia (Appendix B, Table B4).

Mashour et al. (2012) performed a randomized control trial comparing BIS with ETAG monitoring. The primary outcome measured was the incidence rate of IA. Patients were interviewed one time by telephone 28-30 days after surgery using the Brice Interview. For each patient that reported awareness, researchers conducted an additional, more in-depth, interview with an expert. Three to four expert reviewers determined if the event was definite, possible, or no awareness. Findings indicated 11 cases of IA in the 
ETAG group (9,376 participants) and 8 cases in the BIS group (9,460 participants). The authors reported no significant difference $(p=0.48)$ in IA between the two groups. There were some mechanical difficulties experienced in the study, and as a result of these difficulties, a post hoc analysis was conducted comparing a BIS protocol with a nonintervention group, which indicated a 4.7-fold reduction in definite or possible IA for patients using the BIS monitor. A limitation of the study was its early termination because of futility in the obtained results (Appendix B, Table B5).

Avidan et al. (2011) conducted a prospective, randomized control trial that was similar to a study the lead author conducted in 2008. The authors utilized multiple medical centers in the 2011 study rather than a single center as in 2008 . Avidan et al. (2011) compared the use of a BIS protocol with an ETAG protocol for the prevention of IA. Participants were at high-risk for IA. Intraoperative awareness was evaluated utilizing the modified Brice Questionnaire three days after surgery and was administered again 30 days after extubation. Three expert reviewers determined if IA was experienced, and if consensus was not reached, there was a fourth expert reviewer from the ASA who would make the final decision. Results were similar to the author's prior study, as 7 out of 2,861 participants in the BIS group experienced IA while only 2 out of 2,852 patients in the ETAG group had IA which were not statistically significant results $(p=0.98)$ (Appendix B, Table B6).

Forman (2006) conducted a literature review on the concept and controversies of IA. The author examined the effect of anesthetics on the brain, how different levels of minimum alveolar concentration (MAC) affect people unpredictably, and how IA can be characterized. Forman described how IA can be considered definitive, risk factors for IA, 
psychological ramifications, and strategies to prevent IA. In addition, the author reviewed EEG monitors, BIS, and compared the results of several studies. Forman proposed that the most critical beneficial aspect of general anesthesia is the ability to prevent memories, awareness, and patient movement; however, elimination of these functions takes place at dissimilar levels of anesthesia. The author described how the advent of neuromuscular blockers enabled surgeons to have the still and free-ofmovement surgical site that they are looking for, but that anesthesia providers must closely observe other autonomic responses to aid in determining anesthesia depth. Forman (2006) defines IA by its length of time, if the patient has pain and/or anxiety, and if the patient has explicit recall. The most extreme and worst case of IA is when the patient is experiencing pain and paralyzed but aware of what is occurring. Fortunately, the majority of cases of IA with recall are short and without pain. In addition, Forman (2006) described a lesser level of awareness without recall where indistinct memories occur which may be related to intraoperative incidents. Patients may also have dreamlike occurrences, which have been shown to be associated with intraoperative proceedings. Forman (2006) stated that being able to definitively describe IA would require the patient to actually remember music or certain conversations that took place intraoperatively and it is possible that some patients may not remember such events until days to weeks later. Furthermore, the author stated that risk factors for IA can range from equipment issues, the type of surgery, to patient-related factors such as alcohol or drug use. In order to take a preventative approach, the author provided a table of checklist items that can be instituted. These items include ensuring all equipment is in proper working order, pre-medicating with an amnestic drug, ensuring induction doses are 
sufficient, and consider using earplugs or headphones on high-risk patients. Forman (2006) discussed BIS monitoring and studies that have evaluated its efficacy. The author acknowledged that results have not been consistent and there can be significant financial costs without much benefit to patients. Lastly, Forman (2006) recommended that in high-risk patients, IA should be discussed, and the use of a BIS monitor is acceptable; however, the anesthesia provider needs to determine what is best for the patient through education and preparation. Forman concluded that it is not unusual for monitor manufacturers to have financial connections to either the studies or researchers, which can affect outcomes in research (Appendix B, Table B7).

Apfelbaum et al. (2006) were appointed as members of the American Society of Anesthesiologists (ASA) Practice Advisory Task Force. This task force produced a report on IA and brain function monitoring. Members reviewed the available literature and sent surveys to a group of consultants as well as a randomized group of ASA members. The purpose of the survey was to gather data in order to be able to provide a series of recommendations on IA prevention. Suggestions included a thorough preoperative exam focusing on identifying potential risk factors, ensuring anesthesia machines and devices were properly functioning, the possible use of a benzodiazepine, and the use of intraoperative monitoring techniques to assist in the detection of IA (Appendix B, Table B8).

Kotsovolis and Komminos (2009) described numerous aspects of IA in their article. The authors reviewed how anesthetic medications act on the central nervous system, stages of anesthesia, and intraoperative techniques for estimating anesthesia depth, including brain function monitoring. Risk factors for IA, typical experiences 
patients may have during IA, and steps that should be taken in the event of an episode of IA were discussed. Risk factors included sex, ASA status, type of surgery and anesthesia, among numerous others. The authors discussed the modified Brice protocol and its superiority as an analytic tool for the determination of IA. The authors referred to the technological advancement with the BIS monitor and that it can help prevent IA. The use of BIS lowers costs, reduces morbidity and mortality, and helps ensure all resources are utilized. In addition, the authors recommended a stringent preoperative evaluation to determine the extent of risk factors and discussed preventative techniques to help reduce the possibility of IA. These preventative techniques included ensuring the anesthesia machine and other devices were in proper working condition, communicating the possibility of IA to high-risk patients, and careful titration of inhaled and intravenous medication dosages in order to minimize the use of neuromuscular blockers. In conclusion, Kotsovolis and Komminos (2009) proposed that BIS is the only reliable monitor, although it is not necessarily a cost-effective intervention and would need to be used 138 times in order to prevent one case of IA (Appendix B, Table B9).

Castellon-Larios et al. (2016) conducted a non-systematic review. The authors reviewed studies that examined BIS and IA. Castellon-Larios et al. (2016) concluded that BIS reduced IA as well as having other positive effects such as decreased recovery time and less anesthetic medication consumption. Castellon-Larios et al. (2016) illustrated some of the causes of IA, which include under dosing of anesthetics, patient related resistance factors such as age, obesity, opioid use, and mechanical problems such as ventilator or IV related mishaps. The authors examined risk factors that can cause IA such as female sex, a history of IA, difficult intubation, ASA status of 4 or greater, 
alcohol use, and cardiovascular surgery. Castellon-Larios et al. (2016) concluded their review with a series of suggestions aimed towards preventing IA. Suggestions included pre-medicating patients with sedatives, such as benzodiazepines that block anterograde memory, ensuring sufficient anesthetics have been given for induction, intubation, and prior to first incision, maintaining a MAC level 0.7 or greater, and judicious use of neuromuscular blockers (Appendix B, Table B10).

\section{Critical Appraisal Results}

Ekman et al.'s (2004) prospective non-randomized trial used a quantitative approach to examine BIS and IA between two groups. There was a good match between the research problem and the methods but overall lacked rigor due to the non-randomized design. It is possible that some anesthesia providers may have modified their typical practice by knowing the BIS monitor was involved in a research study. Researcher bias is a concern, as this study was financed by a grant from the BIS manufacturer (Appendix C, Table C1).

Avidan et al. (2008) compared the use of a BIS-guided protocol to an ETAG protocol on the prevention of IA. This was a randomized control trial and participants were blinded; however, the anesthesia providers were not blinded to the study participants. The initial patient population was calculated by a power analysis to be able to detect the projected $1 \%$ incidence rate in the ETAG group and the $0.1 \%$ rate in the BIS group. The comparison of demographics of both groups were very similar in all aspects except the ETAG group had significantly more patients with neurological disease than the BIS group (22\% versus $17.2 \%$ with a $p$-value of 0.008$)$. A limitation of the study, which the authors acknowledged, is although three to four experts interpreted the 
interview questions to determine if awareness may have occurred, the concept of awareness is fairly subjective. In addition, it is possible the question types themselves may have influenced a patient to think they experienced an awareness episode; however, a positive aspect is that the manufacturer of the BIS monitor had no role in this trial (Appendix C, Table C2).

Sebel et al. (2004) conducted a prospective, nonrandomized, descriptive study to determine the incidence of awareness during general anesthesia and examine if BIS monitoring had any impact. The anesthesiologist decided if the BIS monitor was to be used. There were no outside influences and the anesthesiologist generally was not aware of patient participation in the study. Since BIS monitoring was a secondary and not primary outcome of this study, the data for BIS may be somewhat skewed because the population that did receive BIS monitoring was not randomized and matched with a comparable group of those who did not. In addition, there was no set BIS protocol in place for participants who received BIS monitoring. A limitation of this study was the authors admitted that their awareness results might have been biased towards underestimating awareness because of a loss of follow-up at the post-op interview. Additionally, like other studies involving awareness, the concept of IA can be subjective, and the authors' disclosed estimates of the incidence rate of IA were somewhat moderate (Appendix C, Table C3).

Myles et al. (2004) conducted a double blind, randomized control trial to determine if BIS-guided anesthesia decreased the incidence rate of awareness during surgery. A power analysis was conducted to determine the appropriate sample size and is strength of this study. This was a well-designed research study and the sample 
population was evenly distributed among the groups and the groups were very similar in terms of demographics and anesthesia regimens. There were very few missing data and rigorous statistical analysis was conducted. This study contained some conflicts of interest though, as the BIS manufacturer provided equipment and some undisclosed level of funding for the trial. In addition, the manufacturer covered travel expenses and conferences for one of the researchers (Appendix C, Table C4).

Mashour et al. (2012) conducted a multi-center randomized control trial. Participants were blinded to the BIS group or the ETAG protocol group; anesthesia providers were not blinded. Data was collected without bias as the interviewers were blinded to the participants' group assignment. The researchers conducted a power analysis to target a sample of 14,072 but due to attrition wanted a recruitment sample of 30,000. The study was discontinued because of futility and at the interim analysis point, there was no statistical difference between the two groups, so the researchers chose to end the study. Mashour et al. (2012) disclosed during the first two months of the trial that some BIS monitors failed to function properly due to software problems; however, researchers made the decision to make the BIS group a “no intervention” group and performed a post-hoc analysis with the extra data. Out of the 9,460 BIS patients, this new group was composed of 3,384 of those patients. As a result of the technical difficulty in the BIS group, fidelity was significantly hindered in this study (Appendix C, Table C5).

Avidan et al. (2011) performed an additional RCT comparing BIS and ETAG. Participants were randomized to a group and demographics between the two groups were similar. Anesthesia providers were not blinded to participants. The authors stated the 
results were applicable to high-risk patients who had general anesthesia using either the BIS or ETAG protocol and that these results could not be extrapolated to other populations. It was possible that genetic influences on a patient's resistance to volatile gases might have been unequally randomized between the BIS and ETAG groups. Finally, Avidan et al. (2011) disclosed it was possible that anesthesia providers became desensitized to the protocols and started to find the audio alarms disruptive instead of helpful, which could lead to the providers ignoring the alarms and tainting the data (Appendix C, Table C6).

Forman (2006) conducted a literature review on IA covering topics ranging from central nervous system functions, risk factors, preventative strategies, and brain function monitors. Forman initially looked at studies targeting the incidence rate of IA and referenced a Swedish study with a rate of $0.06 \%$ and a US study with a rate of $0.13 \%$. The author also examined a few BIS studies with contrasting results. Two studies showed a reduction in IA of $80 \%$ while the third study actually resulted in an increase in IA for patients who had used the BIS monitor. However, he noted that these studies can have some limitations and can decrease the validity of results. The potential bias of brain manufacturing companies sponsoring some of these studies is cited. (Appendix C, Table C7).

Apfelbaum et al. (2006) were a group of ten appointed members to a task force by the ASA with a goal of addressing the problem of IA under general anesthesia. The task force acknowledged that there was potential for bias among their group. Two out of the ten task force members received funds or had a financial interest in companies that produced brain function monitors. Among the consultants involved in the advisory of the 
task force, 54\% had similar vested financial interests. Another limitation was the advisory was published although full consensus between the ASA members and the consultants on several topics had not been established (Appendix C, Table C8).

Kotsovolis and Komninos (2009) performed a literature review on IA with topics ranging from the science of anesthetic drugs on the brain to risk factors to intraoperative monitoring techniques to prevention strategies. The authors reviewed several journal articles, which were the basis of their findings. It is a well-organized and logical review in how they flow from IA topic to topic. The authors did not question any of the results from their reviewed articles and integrated the findings into their own article and conclusions. They recommended starting with a thorough preoperative assessment to first determine a patient's risk for IA. If the anesthesia provider determines that the patient is high risk for IA, the authors proposed a set of steps the provider can employ in order to prevent IA, which includes the use of the BIS monitor (Appendix C, Table C9). Castellon-Larios et al. (2016) conducted a literature review to study the positives and negatives of using a BIS monitor to help guide anesthesia and for the prevention of IA. The authors included a meta-analysis in their review, which found a $65.4 \%$ reduction in IA over 12 studies. Castellon-Larios et al. (2016) examined some of the major causes and risk factors of IA and identified the major cause as being insufficient dosing of anesthetics. Their review identified the modified Bryce protocol as the most superior diagnostic tool in the detection of IA ( $p$-value $<0.00001)$. The authors included several suggestions aimed at preventing IA. These mostly were targeted at addressing the major risk factors and contained interventions such as pre-dosing with sedatives that block memory, minimizing the use of neuromuscular blockers, and ensuring the anesthesia 
machines and patients’ intravenous lines are functioning properly. Castellon-Larios et al. (2016) declared that they had no conflicts of interest and received no funding. The major limitation was the authors did not review any studies in which the use of BIS did not result in a reduction of IA (Appendix C, Table C10).

\section{Cross Analysis Results}

The articles utilized in this integrative review were compared and contrasted to identify similarities and differences regarding the effectiveness of BIS monitoring on IA in adult surgical patients undergoing general anesthesia.

Sebel et al. (2004), Ekman et al. (2004), Myles et al. (2004), Avidan et al. (2008), Avidan et al. (2011), and Mashour et al. (2012) all researched BIS and how it impacted the incidence of IA. Sebel et al. (2004) did not analyze BIS as the primary outcome, but rather, as a secondary outcome in their investigation of the incidence rate of IA overall. All of the studies compared a BIS monitored group with a control or comparison group. There were differences in study designs ranging from a prospective, historical approach to randomized double-blinded control trials. Forman (2006), Kotsovolis and Komninos (2009), Castellon-Larios et al. (2016), and Apfelbaum et al. (2006) explored IA in depth

and focused on the science of anesthesia, potential risk factors that might mitigate IA, and recommendations for interventions in the event there is an occurrence of IA.

Ekman et al. (2004) and Myles et al. (2004) were able to obtain statistically significant results where the use of BIS resulted in reduced rates of IA. Avidan et al. (2008), Sebel et al. (2004), Avidan et al. (2011), and Mashour et al. (2012) were unable to duplicate statistically significant results. Avidan et al. (2008) compared a BIS monitored group to an ETAG monitored group and had identical findings in which two 
episodes of IA per group were reported. Sebel et al. (2004) used the BIS monitor at the discretion of the attending anesthesiologist and documented its use in 38\% of cases.

Their results were very similar to Avidan et al. (2008) as it yielded 12 cases of IA in the non-BIS sample and 13 cases of IA in the BIS sample. Mashour et al. (2012) compared the BIS monitor with a control group using minimum alveolar concentration (MAC) and ETAG. Although this study yielded 11 cases of IA in the MAC group and 8 cases in the BIS group, results were not statistically significant. Avidan et al. (2011) yielded more cases of IA in the BIS group than the ETAG group. According to the Fisher's exact test they used, this result signified that their null hypothesis (BIS is not superior to ETAG) should not be rejected.

Although these studies were all identifying the efficacy of the BIS monitor in preventing IA, the studies had some differences among them including the type of patients. Ekman et al. (2004) and Sebel et al. (2004) did not require their patients to have any specific risk factors for IA beyond receiving general anesthesia. The study population in Ekman et al.’s (2004) group had an average ASA status of $1.5 \pm 0.6$. Mashour et al.’s (2012) group was not targeting IA high-risk patients, but they had a significant amount of IA risk factors among their patient population. Avidan et al. (2008) and Avidan et al. (2011) both targeted patients at high-risk for IA and required their patient population to meet certain criteria. Myles et al. (2004) required their patients to have at least one risk factor for IA.

Besides Ekman et al. (2004) and Sebel et al. (2004), the remaining eight articles in this review identified similar risk factors for IA. Common risk factors identified included: the use of anticonvulsants, opiates, benzodiazepines, alcohol, or cocaine; ASA 
status 4 or 5; history of or anticipated difficult intubation; aortic stenosis; cardiac surgery; pulmonary hypertension; significant cardiovascular impairment; lung disease; and renal disease.

Although Forman (2006), Kotsovolis and Komninos (2009), and Castellon-Larios et al. (2016) span over 10 years, they are very similar in their overall structure and content. Forman (2006) and Kotsovolis and Komninos (2009) make reference to 1845 and Horace Wells using nitrous oxide. In addition, articles discussed some of the science of anesthesia including receptor sites, how anesthetics work on the brain, and how memory plays a function in anesthesia and IA. Although Castellon-Larios et al. (2016) did not discuss the science background of anesthesia and IA, the authors investigated numerous studies regarding IA and BIS. Forman (2006), Kotsovolis and Komninos (2009), and Castellon-Larios et al. (2016) described some of the risk factors associated with IA, brain function monitors, and prevention strategies that can be employed. Some of the common prevention strategies mentioned in all studies include: checking the anesthesia equipment, pumps, and monitors to ensure proper functioning; discussing the possibility of IA with high-risk patients; adequate anesthetic dosing during induction; and judicious use of neuromuscular blockers.

Apfelbaum et al.’s (2006) article was similar to Forman (2006), Kotsovolis and Komninos (2009), and Castellon-Larios et al. (2016) and the authors actually referenced these subsequent articles in their literature. The advisory begins with defining some of the key terms including general anesthesia, amnesia, intraoperative awareness, and brain function monitors. It explains the purpose of this advisory which is to help providers recognize risk factors for IA, provide tools and guidelines to help prevent IA's 
occurrence, and recommends brain function monitors. Apfelbaum et al. (2006) also conducted a comprehensive literature review to assist in developing recommended guidelines. The authors looked for evidence linkages, which would indicate relationships between IA and effective interventions. A key point in their literature search was the admission that since IA occurrence is such a low-probability, the sample size for an RCT would need to be extremely large. Furthermore, while useful data can be obtained by examining sub-groups, such as high-risk patients, in more detail, the generalizability of results may not relate very well to the larger group of all general anesthesia patients (Appendix D).

Next, the summary and conclusions will be discussed. 


\section{Summary and Conclusions}

Intraoperative awareness occurs when a patient has undergone general anesthesia and becomes conscious during the procedure, then consequently forms memories, or has recall of events that occurred during the surgical procedure (Apfelbaum et al., 2006). Intraoperative awareness is not a frequent occurrence but studies have reported it can be severe enough to cause PTSD (Leslie et al., 2010). Amnesia is one of the goals of general anesthesia and the idea of awareness during a surgical procedure can be severely distressing to a patient. Patients who are aware and have recall of these events report extreme feelings ranging from panic attacks to oncoming death. Intraoperative awareness can contribute to depression, problems sleeping, and possibly avoiding hospitals in the future (Sullivan, 2016). Intraoperative awareness cannot be detected intraoperatively as most patients are either sedated, intubated, paralyzed, anesthetized, or a combination of the above. This prompted the ASA to acknowledge that IA is something that cannot be measured intraoperatively and can only be recognized post-operatively by questioning the patient; however, the ASA did conclude that brain activity monitors should be used for patients that have certain risk factors for IA or with certain types of procedures (Apfelbaum et al., 2006).

Bispectral index monitoring (BIS) is a monitoring system that is used by some institutions intraoperatively, which allows anesthesia practitioners to have real-time measurements of a patient's EEG signals. It is intended as a tool to guide practitioners in determining a patient's depth of anesthesia. It is often used in critical care areas when patients have received neuromuscular blockers and sedatives to gauge a patient's depth of sedation. BIS values range from 100 , which is correlated with an awake patient, to 0 , 
which indicates no electrical brain activity. It is typically thought that intraoperatively targeting a range of 40-60 on this continuum allows for reduced patient awareness while simultaneously enabling practitioners to titrate anesthesia medications (Nagelhout \& Plaus, 2014). Successfully reducing anesthetic use while preventing patient awareness results in quicker emergence from anesthesia, decreased post-anesthesia care unit (PACU) times, hospital lengths of stay, and increased operating room (OR) turnover due to shorter procedure times.

The purpose of this paper was to conduct an integrative review to examine the effectiveness of BIS monitoring on IA in adult surgical patients undergoing general anesthesia. Unfortunately, the data that was examined had widely conflicting results. Literature examined found that BIS monitoring can be effective in reducing incidences of IA in certain high-risk populations as demonstrated by Myles et al. (2004). The authors reported an $82 \%$ reduction in the rate of IA in a patient population that had at least 1 IA high-risk factor (high-risk cardiac surgery, aortic stenosis, rigid bronchoscopy, severe end-stage lung disease, anticipated difficult intubation, current use of alcohol, benzodiazepines or opioids). Other studies have indicated that ETAG monitoring is equal if not superior in the prevention of IA (Avidan et al., 2008; Avidan et al., 2011; \& Mashour et al., 2012). Ekman et al. (2004) reported that the use of BIS resulted in a statistically significant reduction in IA, but their study had some major issues. First, their average patient profile was significantly healthier than the other studies as evident by their low ASA status (1.5 \pm 0.6). Avidan et al. (2008) and Myles et al. (2004) both had over $70 \%$ of their patients being ASA 3 or 4 . Avidan et al. (2011) had over $80 \%$ of their patients being ASA 3 or 4. Although Sebel et al. (2004) had 50\% of their patients being 
ASA 2, they still had over 30\% of patients being ASA 3-5. The other concern of this study (Ekman et al., 2004) and others (Sebel et al., 2004 \& Myles et al., 2004) was a potential source of bias. The study by Ekman et al. (2004) was supported by a grant from the BIS manufacturer, which is a potential conflict of interest. The study by Myles et al. (2004), which reported an 82\% reduction in IA using the BIS, had a similar bias issue. One of the lead authors declared that they had received financial support for travel and conference expenses from the BIS manufacturer. Additionally, Myles et al. (2004) acknowledged that they had used loaned equipment and received unrestricted funding from the same company. Sebel et al. (2004) used BIS in 38\% of its patients and also declared having received statistical analysis and processing support from the BIS manufacturer. The other three studies (Avidan et al., 2008, Avidan et al., 2011, \& Mashour et al., 2012) did not declare any potential sources of conflict and also did not report that BIS was superior in preventing IA.

This integrative review had limitations that occurred when researching a topic such as IA, which has such a low occurrence rate. It is exceedingly difficult to find randomized controlled trials with large enough sample sizes (determined by a power analysis) while trying to control for patient factors and variables (such as male/female ratio, ASA status, risk assessment for IA). The quantitative studies all had numerous differences between them including patient characteristics. Some studies included all general anesthesia patients while others targeted patients at high risk for IA. Lastly, knowing the BIS manufacturer funded some studies, which reported reduction rates in IA when the BIS monitor was used, should not be overlooked. 
After conducting this integrative review, this author concludes that the BIS monitor may serve as a useful adjunct monitoring tool but should not be utilized as a primary source in determining a patient's anesthetic. The reviewed evidence does not support BIS monitoring as a means of preventing IA. In the articles reviewed, similarities existed in IA patient risk factors and preventative strategies. Anesthesia providers must conduct a thorough preoperative assessment in order to determine if a patient would be at an increased risk of experiencing IA. Risk factors include: ASA status of 4 or 5, type of surgery, history of IA, opiate or alcohol use, and significant comorbidities. Preventative strategies include making sure all equipment is checked and operational, pre-medicating patients with an amnestic such as a benzodiazepine, using neuromuscular blockers judiciously, and avoiding light inductions. It is also recommended to discuss the possibility of IA with patients at high-risk for IA. Lastly, the use of a BIS monitor for high-risk patients may have some value, but it should not be used as the only method in making the decision to adjust a patient's intraoperative anesthetic. BIS (as well as ETAG monitoring) should be used as an adjunct along with the other data that is readily available to monitor for IA.

The BIS monitor may help to prevent IA for general anesthesia, although its use as a standard of practice for all general anesthesia cases is unfounded. Certain cases and patient characteristics may warrant the use of the BIS monitor but routine usage is not recommended according to the existing data. 


\section{Recommendations and Implications for Advanced Nursing Practice}

Although IA is a very rare occurrence, any episode encountered by a patient can have traumatic and crippling effects. Findings from this integrative review propose that IA cannot be prevented $100 \%$ of the time, regardless of anesthetic medication, monitoring modalities, and other techniques used, therefore, Certified Registered Nurse Anesthetists (CRNAs) need to consider IA on a case-by-case basis based on risk factors.

A detailed preoperative assessment is necessary. It is important to obtain a thorough medical history including any past experiences of IA. Past negative experiences with anesthesia, type of anesthesia the patient received with the negative experience, and type of surgery or procedure are additional information that should be obtained. Certain procedures, which increase the risk of experiencing IA, include cardiac surgery, C-section, trauma, and rigid bronchoscopy. There are numerous patient characteristics that can increase a patient's risk for IA which can include aortic stenosis, pulmonary hypertension, an ASA status of four or greater, end-stage lung disease, an ejection fraction of less than $40 \%$, chronic alcohol consumption, the use of opiates, benzodiazepines or anticonvulsant drugs, muscle relaxants, tracheal intubation, and an opioid-nitrous oxide anesthetic plan. A comprehensive preoperative assessment may identify patients at risk for IA and allow CRNAs to alter their anesthetic plan.

In addition, one of the most common reasons for a patient to experience IA is under dosing of anesthesia. CRNAs can preclude this from being a factor by performing an anesthesia machine check at the beginning of the day and between cases. IV pumps should be checked routinely to ensure they are functioning properly and periodic IV site assessment can be done to ensure that infiltration or leaking is not an issue. Failure in 
any of these areas can lead to an under dosing of anesthesia and potentially, an IA occurrence. Furthermore, the use of a preoperative benzodiazepine can aid in the reduction of IA while also providing some anxiety relief for the patient. Benzodiazepines are beneficial when a patient is hemodynamically unstable and can assist in reducing the overall anesthetic requirements intraoperatively.

Prior to the start of a procedure requiring general anesthesia, a decision should be made whether or not to use BIS monitoring. If a patient has several risk factors or a history of IA, the use of a BIS monitor is justified. Lastly, the CRNA should discuss with high-risk patients the possibility of IA occurring. In conclusion, due to the lack of consensus regarding the use of BIS for every patient undergoing general anesthesia, at their discretion, CRNAs may choose to employ BIS as an extra monitoring tool in the prevention of IA. 


\section{References}

American Association of Nurse Anesthetists (AANA) (2009). Intraoperative Awareness Under General Anesthesia. Retrieved from http://www.aana.com/resources2/bookstore/Documents/awarenessbrochure0110. pdf

American Association of Nurse Anesthetists (AANA) (2013). Standards for Nurse Anesthesia Practice. Retrieved from https://www.aana.com/docs/defaultsource/practice-aana-com-web -documents-(all)/standards-for-nurse-anesthesiapractice.pdf?sfvrsn=e00049b1_2

American Psychological Association (APA) (2017). Clinical Practice Guideline for the Treatment of PTSD. Retrieved from https://www.apa.org/ptsd-guideline/ptsd.pdf Apfelbaum, J.L., Arens, J.F., Cole, D.J., Connis, R.T., Domino, K.B., Drummond, J.C.,...Todd, M.M. (2006). Practice advisory for intraoperative awareness and brain function monitoring: A report by the American society of anesthesiologists task force on intraoperative awareness. Anesthesiology, 104(4), 847-864.

Avidan, M.S., Jacobsohn, E., Glick, D., Burnside, B., Zhang, L., Villafranca, A.,... Mashour, G. (2011). Prevention of intraoperative awareness in a high-risk surgical population. New England Journal of Medicine, 367(7), 591-600. doi: 10.1056/NEJMoa1100403

Avidan, M.S., \& Sleigh, J.W. (2014). Beware the Boojum: the NAP5 audit of accidental awareness during intended general anaesthesia. Anaesthesia, 69(10), 1065-1068. doi:10.1111/anae.12828 
Avidan, M., Zhang, L., Burnside, B., Finkel, K., Searleman, A., Selvidge, J.,...Evers, A. (2008). Anesthesia awareness and the bispectral index. New England Journal of Medicine, 358(11), 1097-1108.

Buttenworth IV, J.F., Mackey, D.C., \& Wasnick, J.D. (2013). Morgan \& Mikhail’s Clinical Anesthesiology. The McGraw-Hill Companies.

Castellon-Larios K., Rosero, B.R., Nino-de Mejia, M.C., Bergese, S.D. (2016). The use of cerebral monitoring for intraoperative awareness. Rev Colomb Anestesiol, 44(1), 23-29.

Ekman, A., Lindholm, M., Lennmarken, C., \& Sandin, R. (2004). Reduction in the incidence of awareness using BIS monitoring. Acta Anaesthesiologica Scandinavica, 48(1), 20-26.

Forman, S. (2006). Awareness during general anesthesia: Concepts and controversies. Seminars In Anesthesia, Perioperative Medicine \& Pain, 25(4), 211-218.

Gelfand, M., Gabriel, R., Gimlick, R., Beutler, S., \& Urman, R. (2017). Practice patterns in the intraoperative use of bispectral index monitoring. Journal Of Clinical Monitoring \& Computing, 31(2), 281-289. doi:10.1007/s10877-016-9845-5

Gonzalo, A.G. (2011). Betty Neuman The Neuman Systems Model. Theoretical Foundations of Nursing. Retrieved from http://nursingtheories.weebly.com/bettyneuman.html

Hernandez, J.F., Secrest, J.A., Hill, L., and McClarty, S.J. (2009). Scientific advances in the genetic understanding and diagnosis of malignant hyperthermia. Journal of PeriAnesthesia Nursing.24(1), 19-34. Retreived from https://doi.org/10.1016/j.jopan.2008.12.001 
Ibrahim, A., Taraday, J., \& Kharasch, E. (2001). Bispectral index monitoring during sedation with sevoflurane, midazolam, and propofol. Anesthesiology, 95(5), 1151-1159.

Kelley, S. T. (2012). Monitoring Consciousness Using the Bispectral Index (BIS) During Anesthesia. Retrieved from http://www.covidien.com/imageServer.aspx/doc252087.pdf?contentID=77508 \&contenttype=application/pdf

Kotsovolis, G., \& Komninos, G. (2009). Awareness during anesthesia: How sure can we be that the patient is sleeping indeed?. Hippokratia, 13(2), 83-89.

Kurehara, K., Horiuch, T., Takahash, M., Kitaguchi, K., \& Furuya, H. (2001). A case of awareness during propofol anesthesia using bispectral index as an indicator of hypnotic effect. Masui. The Japanese Journal Of Anesthesiology, 50(8), 886889.

Leslie, K., Chan, M. V., Myles, P. S., Forbes, A., \& McCulloch, T. J. (2010). Posttraumatic stress disorder in aware patients from the B-aware trial. Anesthesia And Analgesia, 110(3), 823-828. doi:10.1213/ANE.0b013e3181b8b6ca

Lindholm, M., Träff, S., Granath, F., Greenwald, S. D., Ekbom, A., Lennmarken, C., \& Sandin, R. H. (2009). Mortality within 2 years after surgery in relation to low intraoperative bispectral index values and preexisting malignant disease. Anesthesia And Analgesia, 108(2), 508-512. doi:10.1213/ane.0b013e31818f603c 
Mashour, G., Shanks, A., Tremper, K., Kheterpal, S., Turner, C., Ramachandran, S.,... Avidan, M. (2012). Prevention of intraoperative awareness with explicit recall in an unselected surgical population: A randomized comparative effectiveness trial. Anesthesiology, 117(4), 717-725.

Miller, R.D., Cohen, N.H., Eriksson, L.I., Fleisher, L.A., Wiener-Kronish, J.P., \& Young W.L. (2015). Miller's Anesthesia. Philadelphia, PA: Elsevier Saunders.

Moher, D., Liberati, A., Tetzlaff, J., \& Altman, D.G. The PRISMA Group (2009). Preferred Reporting Items for Systematic Reviews and Meta-Analyses: The PRISMA Statement. PLoS Med 6(7): e1000097. doi:10.1371/journal.pmed1000097

Monk, T. G., \& Weldon, B. C. (2011). Does depth of anesthesia monitoring improve postoperative outcomes? Current Opinion In Anesthesiology, 24(6), 665-669.

Myles, P., Leslie, K., McNeil, J., Forbes, A., \& Chan, M. (2004). Bispectral index monitoring to prevent awareness during anaesthesia: the B-Aware randomized controlled trial. Lancet, 363, North American Edition (9423), 1757-1763.

Nagelhout, J. \& Plaus, K. (2014). Clinical Monitoring III: Neurologic System. Nurse Anesthesia,pp.328-329. St Louis, MO: Elseveier Saunders.

O'Connor, M., Daves, S., Tung, A., Cook, R., Thisted, R., \& Apfelbaum, J. (2001). BIS monitoring to prevent awareness during general anesthesia. Anesthesiology, 94(3), 520-529.

Polit, D.F., \& Beck, C.T. (2017). Nursing research generating and assessing evidence for nursing practice. Philadelphia: Wolters Kluwer. 
Schneider, Z., Whitehead, D., LoBiondo-Wood, G., \& Haber, J. (2012). Searching and reviewing the research literature. Nursing and Midwifery Research Methods and Appraisal for Evidenced Based Practice, pp. 35-56. Mosby, Australia:

Elsevier.

Sebel, P. S., Bowdle, T. A., Ghoneim, M. M., Rampil, I. J., Padilla, R. E., Gan, T. J., \& Domino, K. B. (2004). The incidence of awareness during anesthesia: a multicenter United States study. Anesthesia And Analgesia, 99(3), 833.

Stein, E. J., \& Glick, D. B. (2016). Advances in awareness monitoring technologies. Current Opinion In Anesthesiology, 29(6), 711-716. doi:10.1097/ACO.0000000000000387

Sullivan, C. (2016). Awareness with recall: A systematic review. AANA Journal, 84(4), 283-288. 


\section{Appendix A}

\section{PRISMA 2009 Flow Diagram}
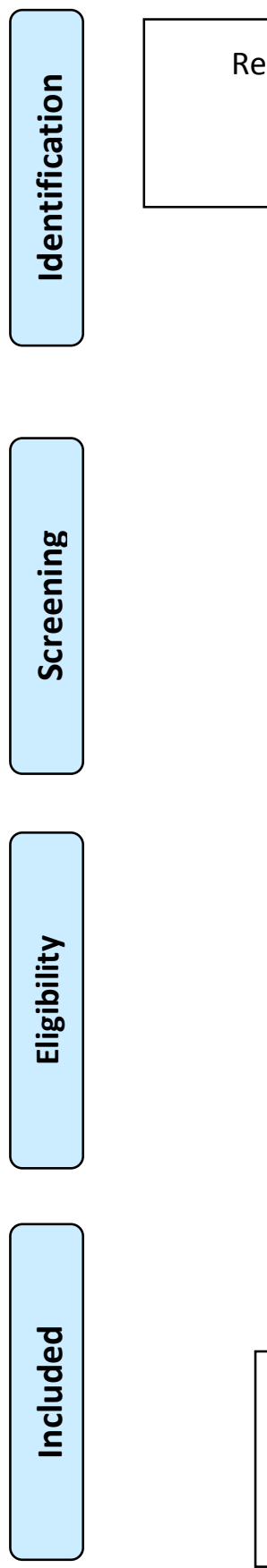
Records identified through database searching

$(n=665)$

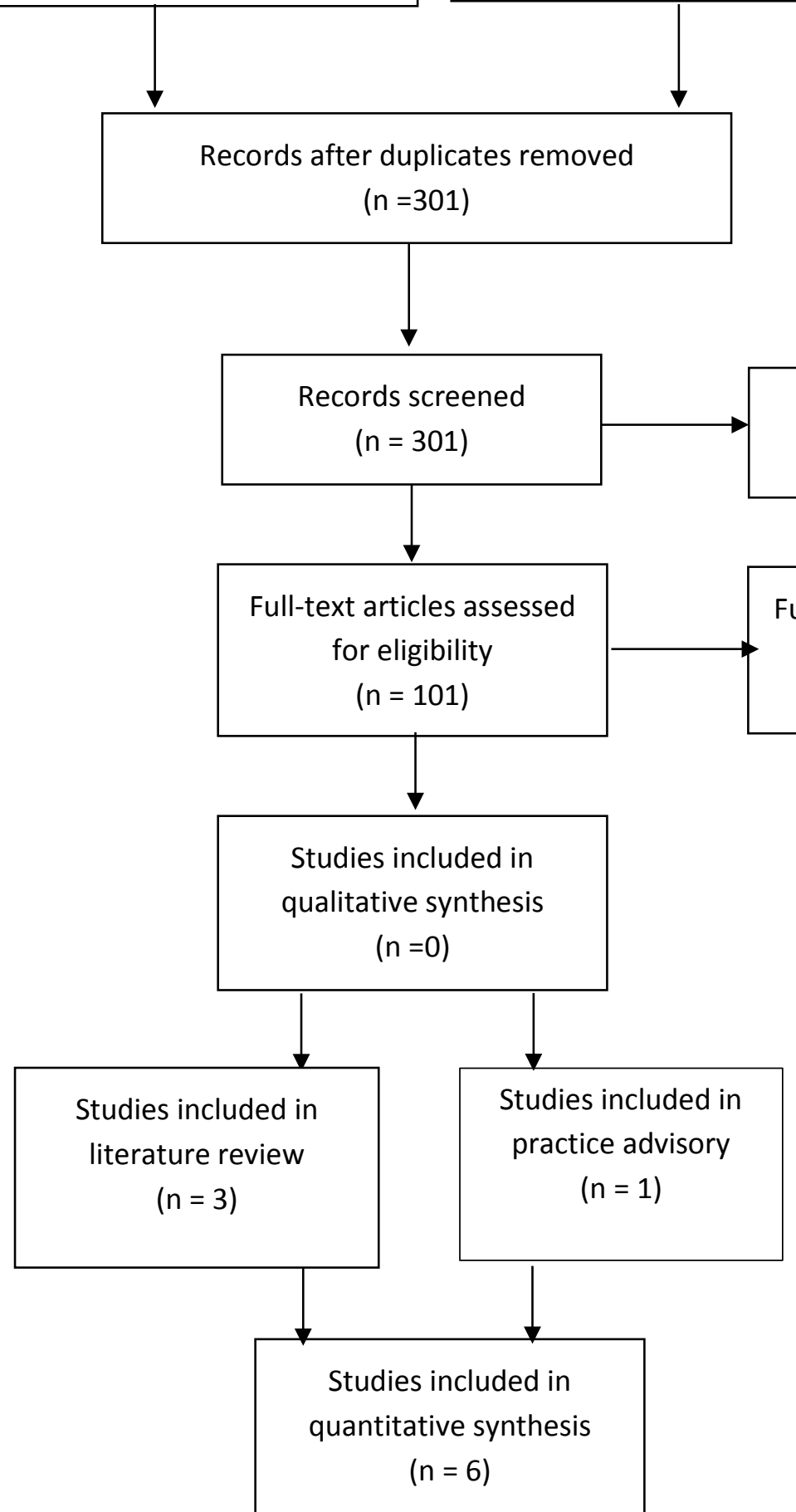

Records excluded

$(n=200)$

Full-text articles excluded, with reasons

$(n=91)$ 


\section{Appendix B}

\section{Table B1}

Ekman, A., Lindholm, M., Lennmarken, C., \& Sandin, R. (2004). Reduction in the incidence of awareness using BIS monitoring. Acta Anaesthesiologica Scandinavica, 48(1), 20-26.

\begin{tabular}{|c|c|c|c|c|c|c|}
\hline Purpose & Design & Sample & Methods & Data Analysis & Results & Limitations \\
\hline $\begin{array}{l}\text { To compare a } \\
\text { prospective } \\
\text { group of patients } \\
\text { with a historical } \\
\text { group of patients } \\
\text { who required } \\
\text { muscle relaxants } \\
\text { and/or intubation } \\
\text { and identify if } \\
\text { the use of the } \\
\text { BIS monitor } \\
\text { reduced the } \\
\text { incidence of IA }\end{array}$ & $\begin{array}{l}\text { Prospective, } \\
\text { historical, } \\
\text { controlled, } \\
\text { cohort trial } \\
\text { design } \\
\text { completed at two } \\
\text { Swedish } \\
\text { hospitals. }\end{array}$ & $\begin{array}{l}\text { The sample } \\
\text { consisted of } \\
7,826 \text { patients in } \\
\text { the historical } \\
\text { group and 4,945 } \\
\text { patients in the } \\
\text { BIS monitored } \\
\text { group. Patients } \\
\text { were } 16 \text { and } \\
\text { older, able to } \\
\text { communicate in } \\
\text { Swedish or } \\
\text { English, not } \\
\text { having surgery } \\
\text { that precluded } \\
\text { the use of the } \\
\text { BIS sensors on } \\
\text { foreheads, and } \\
\text { able to complete }\end{array}$ & $\begin{array}{l}\text { This was an IRB } \\
\text { approved study } \\
\text { conducted by } \\
\text { staff who } \\
\text { regularly gave } \\
\text { anesthesia. BIS } \\
\text { monitors were } \\
\text { installed in all } \\
\text { operating rooms. } \\
\text { Staff were } \\
\text { educated on the } \\
\text { use of BIS along } \\
\text { with repeated } \\
\text { education } 1 \text { year } \\
\text { later. Patients } \\
\text { were interviewed } \\
\text { before they left } \\
\text { the PACU, 1-3 } \\
\text { days later, and }\end{array}$ & $\begin{array}{l}\text { Analyses were } \\
\text { completed on an } \\
\text { intention-to-treat } \\
\text { basis depending } \\
\text { on whether BIS } \\
\text { had been used or } \\
\text { not. Additional } \\
\text { analytical tools } \\
\text { used included } \\
\text { Fisher's exact } \\
\text { test, the } \\
\text { Student's t-test, } \\
\text { double-sided, or } \\
\text { the Chi-square } \\
\text { test with Yate's } \\
\text { correction. }\end{array}$ & $\begin{array}{l}\text { There were two } \\
\text { cases of IA in } \\
\text { the BIS } \\
\text { monitored group } \\
\text { and } 14 \text { in the } \\
\text { historical control } \\
\text { group. This was } \\
\text { a statistically } \\
\text { significant result } \\
\text { with a p-value of } \\
0.019 \text { and } 0.038 \\
\text { according to the } \\
\text { Fisher's exact } \\
\text { single-sided and } \\
\text { double-sided } \\
\text { tests, } \\
\text { respectively. }\end{array}$ & $\begin{array}{l}\text { Due to the non- } \\
\text { randomization. } \\
\text { once anesthesia } \\
\text { providers } \\
\text { understood that } \\
\text { the BIS monitor } \\
\text { was being } \\
\text { studied, it is } \\
\text { possible that } \\
\text { they changed } \\
\text { their anesthetic } \\
\text { technique to take } \\
\text { that into account. } \\
\text { The BIS } \\
\text { monitored group } \\
\text { had an increased } \\
\text { percentage of } \\
\text { patients who had } \\
\text { ETAG }\end{array}$ \\
\hline
\end{tabular}




\begin{tabular}{|l|l|l|l|l|l|}
\hline & $\begin{array}{l}\text { the last two } \\
\text { interviews for } \\
\text { awareness. }\end{array}$ & $\begin{array}{l}\text { then 7- 14 days } \\
\text { after the } \\
\text { operation. They } \\
\text { were interviewed } \\
\text { using the } \\
\text { modified Brice } \\
\text { interview. }\end{array}$ & $\begin{array}{l}\text { monitoring } \\
\text { which might } \\
\text { have contributed } \\
\text { to the findings. } \\
\text { Finally, } \\
\text { distinguishing } \\
\text { between actual } \\
\text { IA and other } \\
\text { memories is not } \\
\text { always clear as } \\
\text { there were 20 } \\
\text { patients who } \\
\text { were interviewed } \\
\text { more in depth } \\
\text { after the Brice } \\
\text { interview dues to } \\
\text { partial } \\
\text { memories. }\end{array}$ \\
& & & & \\
& & & & \\
& & & \\
& & & \\
\end{tabular}


Table B2

Avidan, M., Zhang ,L., Burnside, B., Finkel, K., Searleman, A., Selvidge, J., Saager, L., Turner, M.T., Rao, S., Bottros, M., Hantler, C., Jacobsohn, E., \& Evers, A. (2008). Anesthesia awareness and the bispectral index. New England Journal of Medicine, 358(11), 1097-1108.

\begin{tabular}{|c|c|c|c|c|c|c|}
\hline Purpose & Design & Sample & Methods & Data Analysis & Results & Limitations \\
\hline $\begin{array}{l}\text { To determine if a } \\
\text { BIS-based } \\
\text { protocol is better } \\
\text { than an ETAG- } \\
\text { based protocol in } \\
\text { preventing IA in } \\
\text { high-risk } \\
\text { patients. }\end{array}$ & $\begin{array}{l}\text { The design was a } \\
\text { single-center, } \\
\text { prospective } \\
\text { study, with pre- } \\
\text { randomization of } \\
\text { patients in } \\
\text { blocks of } 100 \\
\text { with } 50 \text { to each } \\
\text { protocol. }\end{array}$ & $\begin{array}{l}\text { The sample } \\
\text { consisted of } \\
\text { patients who } \\
\text { were } 18 \text { or older; } \\
\text { having surgery } \\
\text { at the Barnes- } \\
\text { Jewish hospital. } \\
\text { Eligibility was } \\
\text { based on } \\
\text { preoperative } \\
\text { assessments } \\
\text { which } \\
\text { determined } \\
\text { which patients } \\
\text { were at high-risk } \\
\text { for IA. There } \\
\text { were } 967 \text { and } \\
974 \text { patients in } \\
\text { the BIS and } \\
\text { ETAG groups, }\end{array}$ & $\begin{array}{l}\text { The study was } \\
\text { approved by the } \\
\text { Washington } \\
\text { University } \\
\text { Human Research } \\
\text { Protection } \\
\text { Office. Patients } \\
\text { were interviewed } \\
\text { for IA at three } \\
\text { intervals after } \\
\text { their surgery (0- } \\
24 \text { hours, 1-3 } \\
\text { days, and } 30 \\
\text { days after } \\
\text { extubation). } \\
\text { Only anesthesia } \\
\text { providers were } \\
\text { aware of which } \\
\text { groups patients } \\
\text { were assigned to }\end{array}$ & $\begin{array}{l}\text { Some of the } \\
\text { statistical } \\
\text { analyses done } \\
\text { included Fisher's } \\
\text { exact test, } \\
\text { Newcombe's } \\
\text { method with } \\
\text { continuity } \\
\text { correction, chi- } \\
\text { square test, } \\
\text { unpaired t-test, } \\
\text { and an unpaired } \\
\text { Mann-Whitney } \\
\text { test. }\end{array}$ & $\begin{array}{l}\text { Two cases of } \\
\text { definite IA } \\
\text { occurred in each } \\
\text { group. The } \\
\text { incidence rates } \\
\text { of definite or } \\
\text { possible IA were } \\
0.62 \% \text { and } \\
0.31 \% \text { in the BIS } \\
\text { and ETAG } \\
\text { groups, } \\
\text { respectively. } \\
\text { There were no } \\
\text { statistically } \\
\text { significant } \\
\text { differences } \\
\text { between the } \\
\text { patients who had } \\
\text { definite or } \\
\text { possible IA and }\end{array}$ & $\begin{array}{l}\text { Limitations } \\
\text { include } \\
\text { diagnosis of IA } \\
\text { can be subjective } \\
\text { and that repeated } \\
\text { interviews can } \\
\text { induce false } \\
\text { memories } \\
\text { rendering them } \\
\text { invalid. } \\
\text { Memories may } \\
\text { be difficult to } \\
\text { distinguish } \\
\text { between OR } \\
\text { events and those } \\
\text { in the ICU. The } \\
\text { providers being } \\
\text { aware of which } \\
\text { group the } \\
\text { patients were in }\end{array}$ \\
\hline
\end{tabular}




\begin{tabular}{|l|l|l|l|l|l|}
\hline & respectively. & $\begin{array}{l}\text { as the patients, } \\
\text { postoperative } \\
\text { reviewers, expert } \\
\text { reviewers, and } \\
\text { statistician did } \\
\text { not have this } \\
\text { information. }\end{array}$
\end{tabular}


Table B3

Sebel, P. S., Bowdle, T. A., Ghoneim, M. M., Rampil, I. J., Padilla, R. E., Gan, T. J., \& Domino, K. B. (2004). The incidence of awareness during anesthesia: a multicenter United States study. Anesthesia and Analgesia, 99(3), 833.

\begin{tabular}{|c|c|c|c|c|c|c|}
\hline Purpose & Design & Sample & Methods & Data Analysis & Results & Limitations \\
\hline $\begin{array}{l}\text { To determine the } \\
\text { incidence rate of } \\
\text { IA during } \\
\text { routine general } \\
\text { anesthesia in the } \\
\text { US along with } \\
\text { trying to } \\
\text { determine the } \\
\text { BIS values that } \\
\text { accompany such } \\
\text { events. }\end{array}$ & $\begin{array}{l}\text { This is a } \\
\text { prospective, } \\
\text { nonrandomized } \\
\text { descriptive } \\
\text { cohort study that } \\
\text { was completed } \\
\text { at seven } \\
\text { academic } \\
\text { medical centers } \\
\text { in the US. }\end{array}$ & $\begin{array}{l}\text { The sample } \\
\text { consisted of } \\
19,575 \text { patients } \\
\text { with 16,544 of } \\
\text { them completing } \\
\text { the initial IA } \\
\text { interview in the } \\
\text { recovery room } \\
\text { and 13,123 } \\
\text { completing the } \\
\text { follow-up } \\
\text { interview. } \\
\text { Inclusion criteria } \\
\text { included patients } \\
\text { receiving general } \\
\text { anesthesia, } \\
\text { people aged } 18 \\
\text { and older, } \\
\text { apparently } \\
\text { normal mental } \\
\text { status, and the }\end{array}$ & $\begin{array}{l}\text { This was an IRB } \\
\text { approved study } \\
\text { at seven } \\
\text { geographically } \\
\text { dispersed } \\
\text { academic } \\
\text { medical centers. } \\
\text { The attending } \\
\text { anesthesiologist } \\
\text { was at liberty to } \\
\text { decide the } \\
\text { anesthetic care } \\
\text { provided as well } \\
\text { as if BIS was to } \\
\text { be utilized or } \\
\text { not. The } \\
\text { anesthesiologist } \\
\text { generally was } \\
\text { not informed of } \\
\text { patient } \\
\text { participation in }\end{array}$ & $\begin{array}{l}\text { Descriptive } \\
\text { statistics were } \\
\text { applied for the } \\
\text { incidence of IA } \\
\text { in the population } \\
\text { sample. Groups } \\
\text { were contrasted } \\
\text { and compared } \\
\text { with Fisher's } \\
\text { exact or } \chi^{2} \text { tests } \\
\text { with Yates' } \\
\text { correction. } \\
\text { Logistic } \\
\text { regression } \\
\text { models were } \\
\text { also employed. } \\
\text { Variables } \\
\text { determined to be } \\
\text { significant in } \\
\text { univariate } \\
\text { analysis were }\end{array}$ & $\begin{array}{l}\text { Out of the } \\
19,575 \text { patients, } \\
\text { a total of } 25 \\
\text { cases of IA were } \\
\text { established. } \\
\text { There were } 46 \\
\text { cases of possible } \\
\text { awareness and } \\
\text { 1,183 cases of } \\
\text { possible } \\
\text { intraoperative } \\
\text { dreaming. } \\
\text { Incidence of IA } \\
\text { correlated with a } \\
\text { higher ASA } \\
\text { physical status. } \\
\text { Age and gender } \\
\text { did not have an } \\
\text { impact on the } \\
\text { rate of IA. BIS } \\
\text { was utilized on }\end{array}$ & $\begin{array}{l}\text { As with all } \\
\text { studies on IA, } \\
\text { authors noted the } \\
\text { possibility that } \\
\text { patients knowing } \\
\text { they are } \\
\text { participating in } \\
\text { an IA study } \\
\text { might increase } \\
\text { the rate of self- } \\
\text { reported } \\
\text { incidents of IA. } \\
\text { It must be noted } \\
\text { that the results of } \\
\text { the BIS monitor } \\
\text { are not } \\
\text { conclusive } \\
\text { because of } \\
\text { several reasons. } \\
\text { The efficacy of } \\
\text { the BIS monitor }\end{array}$ \\
\hline
\end{tabular}




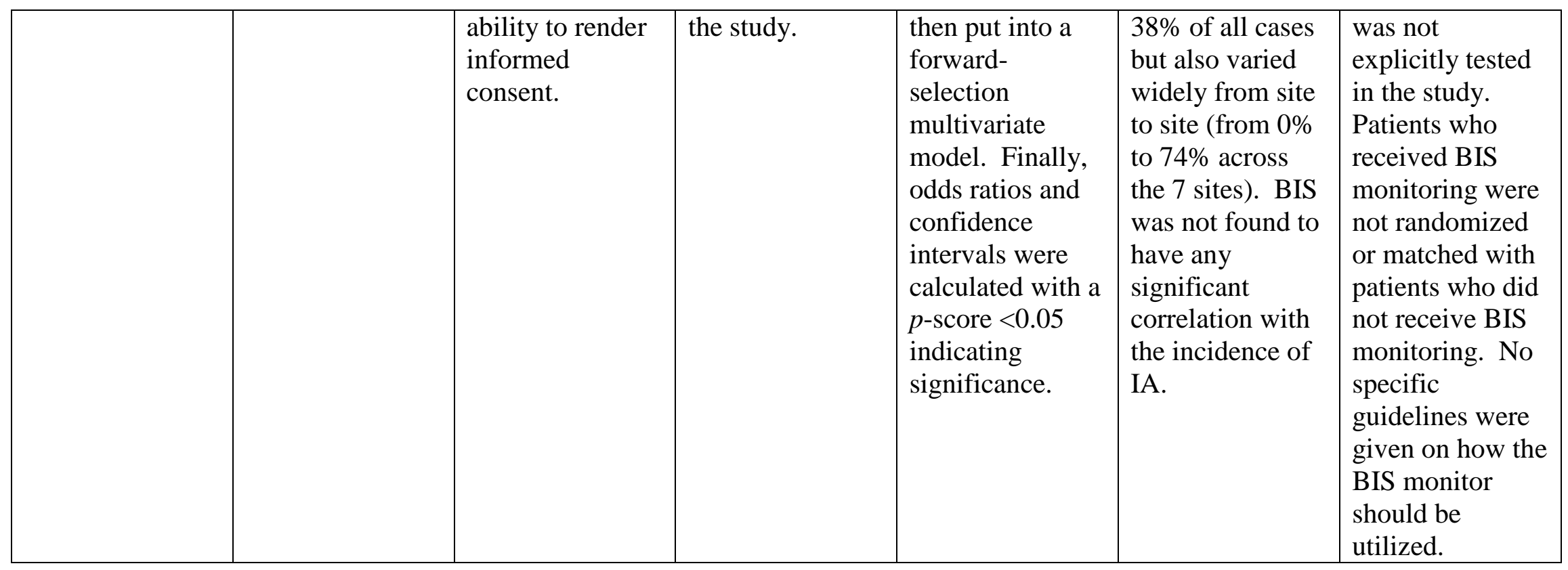


Table B4

Myles, P., Leslie, K., McNeil, J., Forbes, A., \& Chan, M. (2004). Bispectral index monitoring to prevent awareness during anaesthesia: the B-Aware randomized controlled trial. Lancet, 363 North American Edition (9423), 1757-1763.

\begin{tabular}{|c|c|c|c|c|c|c|}
\hline Purpose & Design & Sample & Methods & Data Analysis & Results & Limitations \\
\hline $\begin{array}{l}\text { To examine } \\
\text { whether BIS- } \\
\text { guided } \\
\text { anesthesia would } \\
\text { reduce the rate } \\
\text { of IA during } \\
\text { surgery in high- } \\
\text { risk adults. }\end{array}$ & $\begin{array}{l}\text { The study was a } \\
\text { prospective, } \\
\text { randomized, } \\
\text { double-blind } \\
\text { multi-center } \\
\text { trial. Patients } \\
\text { were interviewed } \\
\text { for IA between } \\
\text { four to six hours, } \\
24-36 \text { hours, and } \\
30 \text { days post- } \\
\text { surgery. }\end{array}$ & $\begin{array}{l}\text { The total sample } \\
\text { consisted of } \\
1,225 \text { patients in } \\
\text { the BIS group } \\
\text { and } 1,238 \\
\text { patients in the } \\
\text { routine care } \\
\text { (control) group. } \\
\text { These patients } \\
\text { were going to } \\
\text { have general } \\
\text { anesthesia along } \\
\text { with a muscle } \\
\text { relaxant. They } \\
\text { also had to have } \\
\text { at least one risk- } \\
\text { factor for IA. }\end{array}$ & $\begin{array}{l}\text { The ethics } \\
\text { committee of } \\
\text { each of the } \\
\text { centers approved } \\
\text { the trial. All } \\
\text { elective surgical } \\
\text { patients gave } \\
\text { written consent } \\
\text { while conscious } \\
\text { emergency } \\
\text { patients gave } \\
\text { verbal consent. } \\
\text { The anesthesia } \\
\text { provider decided } \\
\text { upon anesthesia } \\
\text { agents, muscle } \\
\text { relaxants, and } \\
\text { analgesia drugs } \\
\text { without any } \\
\text { outside } \\
\text { influence. }\end{array}$ & $\begin{array}{l}\text { The primary } \\
\text { outcome of IA } \\
\text { was analyzed } \\
\text { using Fisher's } \\
\text { exact test. Other } \\
\text { statistical tests } \\
\text { used included } \\
\text { Kaplan-Meier } \\
\text { survival curves, } \\
\text { log-rank tests, } \\
\text { Cox proportional } \\
\text { hazards model, } \\
\chi^{2} \text { tests, and the } \\
\text { Wilcoxon rank } \\
\text { sum test. }\end{array}$ & $\begin{array}{l}\text { The BIS group } \\
\text { had } 22 \text { cases of } \\
\text { confirmed or } \\
\text { possible } \\
\text { awareness while } \\
\text { the routine care } \\
\text { (control) group } \\
\text { had } 27 \text { such } \\
\text { events. This was } \\
\text { an } 82 \% \\
\text { reduction in the } \\
\text { risk of IA for } \\
\text { patients that used } \\
\text { BIS monitoring. } \\
\text { Demographics } \\
\text { and clinical } \\
\text { characteristics of } \\
\text { the two groups } \\
\text { was not } \\
\text { significantly } \\
\text { different. An }\end{array}$ & $\begin{array}{l}\text { Bias existed as } \\
\text { the BIS monitor } \\
\text { was loaned from } \\
\text { the manufacturer } \\
\text { as well as them } \\
\text { providing } \\
\text { unrestricted } \\
\text { funding. One of } \\
\text { the lead authors } \\
\text { received } \\
\text { financial support } \\
\text { for travel and } \\
\text { conference } \\
\text { expenses from } \\
\text { the same } \\
\text { company. A } \\
\text { potential } \\
\text { limitation of the } \\
\text { study itself was } \\
\text { that anesthesia } \\
\text { providers in the }\end{array}$ \\
\hline
\end{tabular}




\begin{tabular}{|l|l|l|l|l|}
\hline & & & & $\begin{array}{l}\text { interim analysis } \\
\text { was done after } \\
1,512 \text { patients } \\
\text { have reduced } \\
\text { anesthetic drugs } \\
\text { had enrolled and an earlier time } \\
\text { it was } \\
\text { anhich would } \\
\text { recommended to } \\
\text { continue the } \\
\text { provide a certain } \\
\text { amount of bias. }\end{array}$ \\
\hline
\end{tabular}


Table B5

Mashour, G., Shanks, A., Tremper, K., Kheterpal, S., Turner, C., Ramachandran, S.,... Avidan, M. (2012). Prevention of intraoperative awareness with explicit recall in an unselected surgical population: a randomized comparative effectiveness trial. Anesthesiology, 117(4), 717-725.

\begin{tabular}{|c|c|c|c|c|c|c|}
\hline Purpose & Design & Sample & Methods & Data Analysis & Results & Limitations \\
\hline $\begin{array}{l}\text { To conduct an } \\
\text { efficacy trial } \\
\text { comparing the } \\
\text { BIS monitor } \\
\text { with ETAG to } \\
\text { prevent IA in an } \\
\text { unselected } \\
\text { surgical patient } \\
\text { population. }\end{array}$ & $\begin{array}{l}\text { This was a } \\
\text { randomized } \\
\text { controlled trial } \\
\text { occurring at } \\
\text { three hospitals of } \\
\text { a tertiary } \\
\text { academic } \\
\text { medical center. } \\
\text { Anesthesia } \\
\text { providers were } \\
\text { alerted } \\
\text { electronically } \\
\text { when BIS values } \\
\text { or ETAG values } \\
\text { wavered from } \\
\text { the protocol } \\
\text { range. All } \\
\text { personnel } \\
\text { involved in the } \\
\text { study except for }\end{array}$ & $\begin{array}{l}\text { The patient } \\
\text { sample consisted } \\
\text { of 9,460 patients } \\
\text { in the BIS group } \\
\text { and 9,376 } \\
\text { patients in the } \\
\text { ETAG group. } \\
\text { Due to } \\
\text { unexpected } \\
\text { technical } \\
\text { difficulties, } \\
3,384 \text { patients in } \\
\text { the BIS group } \\
\text { did not end up } \\
\text { having any BIS } \\
\text { data recorded. } \\
\text { Inclusion criteria } \\
\text { included patients } \\
18 \text { and older } \\
\text { who were going }\end{array}$ & $\begin{array}{l}\text { This was a } \\
\text { University of } \\
\text { Michigan IRB } \\
\text { approved study. } \\
\text { Patients had a } \\
\text { thorough } \\
\text { discussion of the } \\
\text { risks and } \\
\text { benefits and } \\
\text { were consented } \\
\text { to the } \\
\text { interventions. A } \\
\text { single interview } \\
\text { was conducted } \\
\text { to screen for IA } \\
\text { 28-30 days after } \\
\text { surgery by } \\
\text { telephone. Any } \\
\text { patient who } \\
\text { reported IA }\end{array}$ & $\begin{array}{l}\text { Primary outcome } \\
\text { of IA between } \\
\text { the groups was } \\
\text { compared using } \\
\text { a modified } \\
\text { intention-to-treat } \\
\text { analysis. A two- } \\
\text { tailed chi-square } \\
\text { test determined } \\
\text { significance. } \\
\text { The Newcombe } \\
\text { method } \\
\text { determined } \\
\text { confidence } \\
\text { intervals. } \\
\text { Linear } \\
\text { regression r- } \\
\text { squared test } \\
\text { compared the } \\
\text { average number }\end{array}$ & $\begin{array}{l}\text { There were } 11 \\
\text { occurrences of } \\
\text { IA out of the } \\
9,376 \text { patients in } \\
\text { the ETAG group } \\
\text { and } 8 \text { out of } \\
\text { 9,460 patients in } \\
\text { the BIS group. } \\
\text { No statistical } \\
\text { significance. As } \\
\text { a result of the } \\
\text { technical } \\
\text { difficulty with } \\
\text { the BIS monitor, } \\
\text { a post hoc } \\
\text { analysis was } \\
\text { done. According } \\
\text { to this analysis, } \\
\text { the sub-cohort of } \\
\text { the BIS group }\end{array}$ & $\begin{array}{l}\text { As the study } \\
\text { itself was } \\
\text { terminated due } \\
\text { to futility, a } \\
\text { limitation was } \\
\text { the inability to } \\
\text { definitively } \\
\text { determine if } \\
\text { there was a } \\
\text { difference in the } \\
\text { IA rate between } \\
\text { the BIS and } \\
\text { ETAG protocols. } \\
\text { The technical } \\
\text { difficulty } \\
\text { encountered by } \\
\text { some of the BIS } \\
\text { cohort was } \\
\text { another } \\
\text { limitation. }\end{array}$ \\
\hline
\end{tabular}




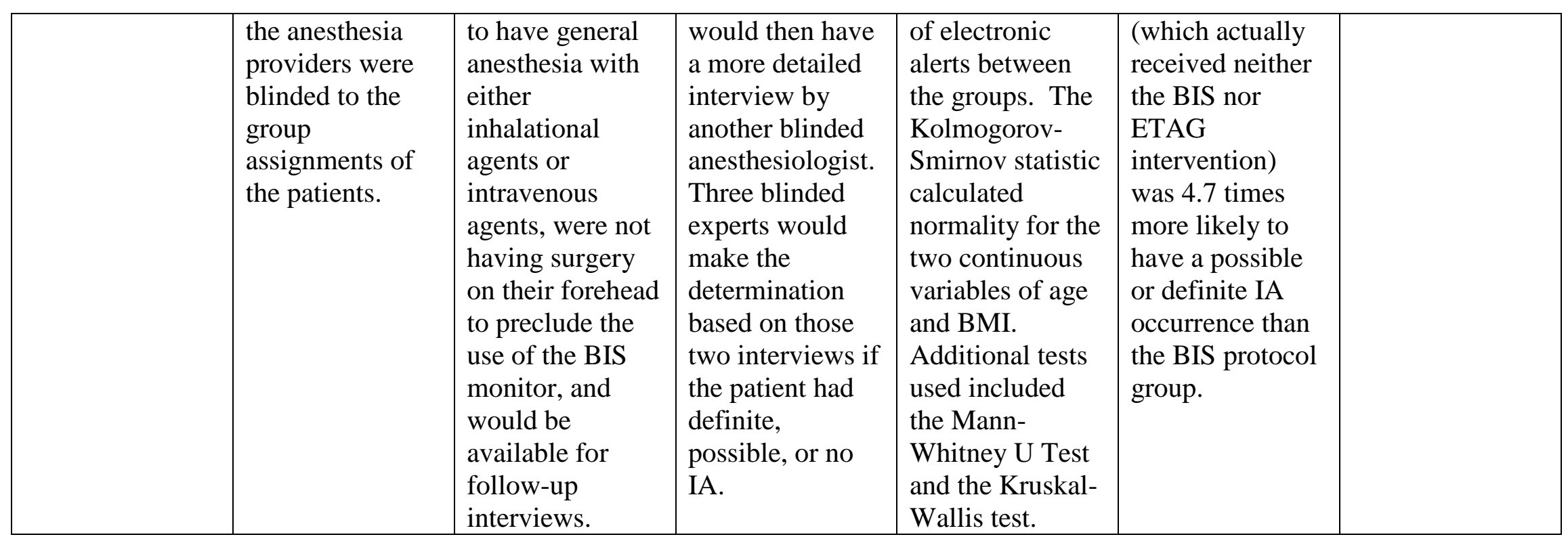


Table B6

Avidan, M.S., Jacobsohn, E., Glick, D., Burnside, B., Zhang, L., Villafranca, A.,...Mashour, G. (2011). Prevention of intraoperative awareness in a high-risk surgical population. New England Journal of Medicine, 367(7), 591-600.

\begin{tabular}{|c|c|c|c|c|c|c|}
\hline Purpose & Design & Sample & Methods & Data Analysis & Results & Limitations \\
\hline $\begin{array}{l}\text { To determine if a } \\
\text { BIS-guided } \\
\text { protocol would } \\
\text { be more } \\
\text { effective than an } \\
\text { ETAG-guided } \\
\text { protocol for the } \\
\text { prevention of IA } \\
\text { in high-risk } \\
\text { patients. }\end{array}$ & $\begin{array}{l}\text { This was a } \\
\text { prospective, } \\
\text { randomized, } \\
\text { evaluator- } \\
\text { blinded trial at } \\
\text { three medical } \\
\text { centers. All staff } \\
\text { associated with } \\
\text { the study were } \\
\text { blinded to the } \\
\text { group } \\
\text { assignments with } \\
\text { the exception of } \\
\text { the anesthesia } \\
\text { providers. } \\
\text { Providers were } \\
\text { not restricted in } \\
\text { how they } \\
\text { managed and } \\
\text { treated their } \\
\text { patients. }\end{array}$ & $\begin{array}{l}\text { The patient } \\
\text { sample consisted } \\
\text { of 2,861 patients } \\
\text { in the BIS group } \\
\text { and 2,852 } \\
\text { patients in the } \\
\text { ETAG group. In } \\
\text { order to be } \\
\text { eligible, patients } \\
\text { needed to be } 18 \\
\text { and older, } \\
\text { having elective } \\
\text { surgery with } \\
\text { general } \\
\text { anesthesia and } \\
\text { using either } \\
\text { isoflurane, } \\
\text { sevoflurane, or } \\
\text { desflurane. } \\
\text { Patients also } \\
\text { needed to be }\end{array}$ & $\begin{array}{l}\text { The human } \\
\text { studies } \\
\text { committees at } \\
\text { Washington } \\
\text { University, } \\
\text { University of } \\
\text { Chicago, and the } \\
\text { University of } \\
\text { Manitoba each } \\
\text { approved this } \\
\text { study. Patients } \\
\text { were interviewed } \\
\text { within } 72 \text { hours } \\
\text { after their } \\
\text { surgery and then } \\
\text { again } 30 \text { days } \\
\text { after they were } \\
\text { extubated. } \\
\text { Patients who } \\
\text { reported } \\
\text { memories or }\end{array}$ & $\begin{array}{l}\text { To determine if } \\
\text { there was a } \\
\text { lower rate of IA } \\
\text { between the BIS } \\
\text { and ETAG } \\
\text { groups, the } \\
\text { authors used a } \\
\text { one-sided } \\
\text { Fischer's exact } \\
\text { test. They also } \\
\text { used a modified } \\
\text { intention-to-treat } \\
\text { analysis. As a } \\
\text { post hoc } \\
\text { secondary } \\
\text { analysis, they } \\
\text { also used a chi- } \\
\text { square test, } \\
\text { unpaired Mann- } \\
\text { Whitney U test, } \\
\text { and an unpaired }\end{array}$ & $\begin{array}{l}\text { Seven patients in } \\
\text { the BIS group } \\
\text { had definite IA } \\
\text { compared to two } \\
\text { patients in the } \\
\text { ETAG group. } \\
\text { There were } 19 \\
\text { cases of definite } \\
\text { or possible IA in } \\
\text { the BIS group } \\
\text { compared to } 8 \\
\text { such events in } \\
\text { the ETAG } \\
\text { group. The BIS } \\
\text { protocol was not } \\
\text { superior to the } \\
\text { ETAG group for } \\
\text { the prevention of } \\
\text { IA. Out of the } \\
5,713 \text { patients in } \\
\text { both groups, }\end{array}$ & $\begin{array}{l}\text { This study was } \\
\text { aimed at } \\
\text { investigating } \\
\text { high-risk for IA } \\
\text { patients using an } \\
\text { inhaled } \\
\text { anesthetic } \\
\text { (general } \\
\text { anesthesia) and } \\
\text { the results } \\
\text { should not be } \\
\text { extrapolated to } \\
\text { other patient and } \\
\text { anesthetic } \\
\text { variables. } \\
\text { Another } \\
\text { limitation } \\
\text { identified by the } \\
\text { authors suggests } \\
\text { that a protocol } \\
\text { that utilized both }\end{array}$ \\
\hline
\end{tabular}




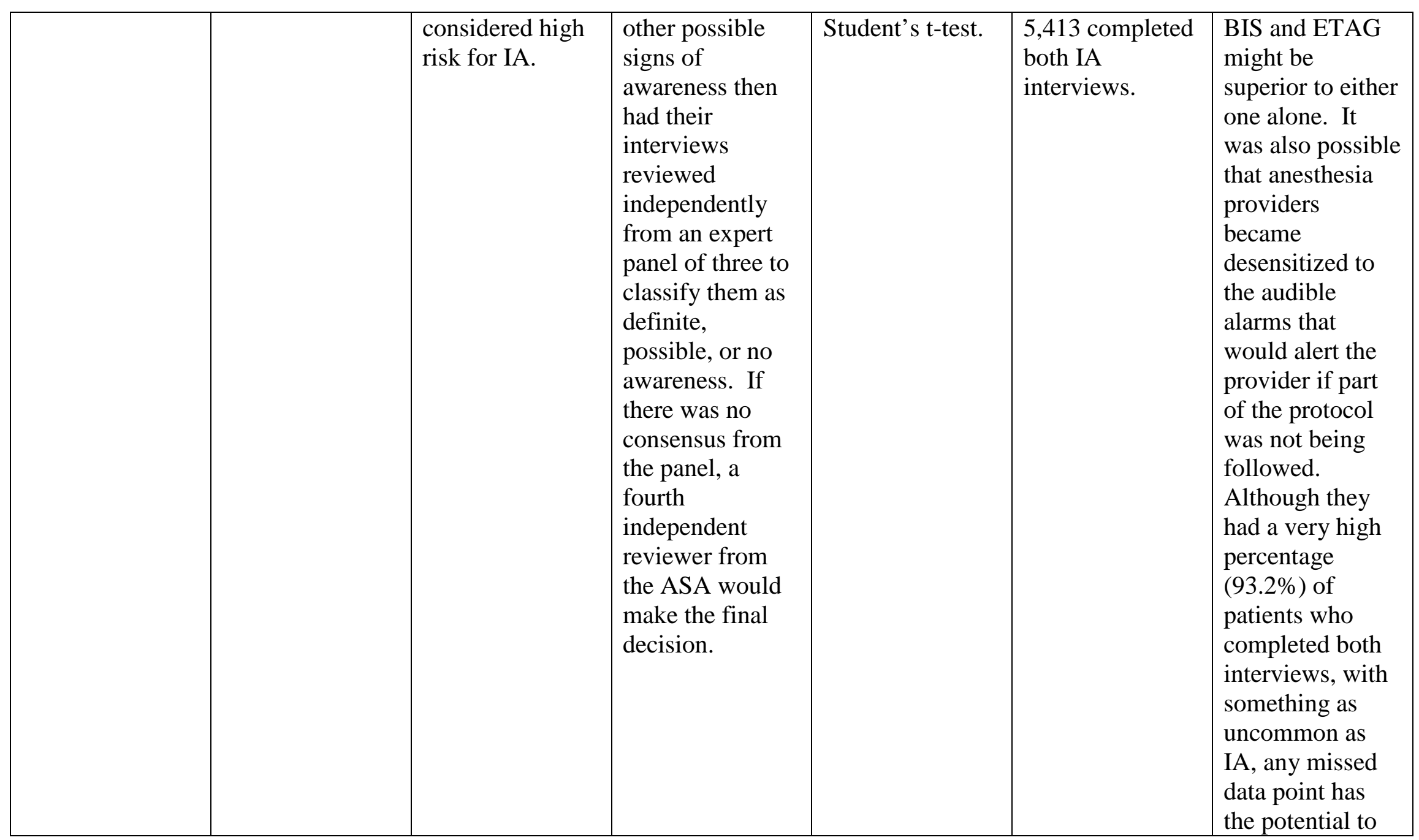




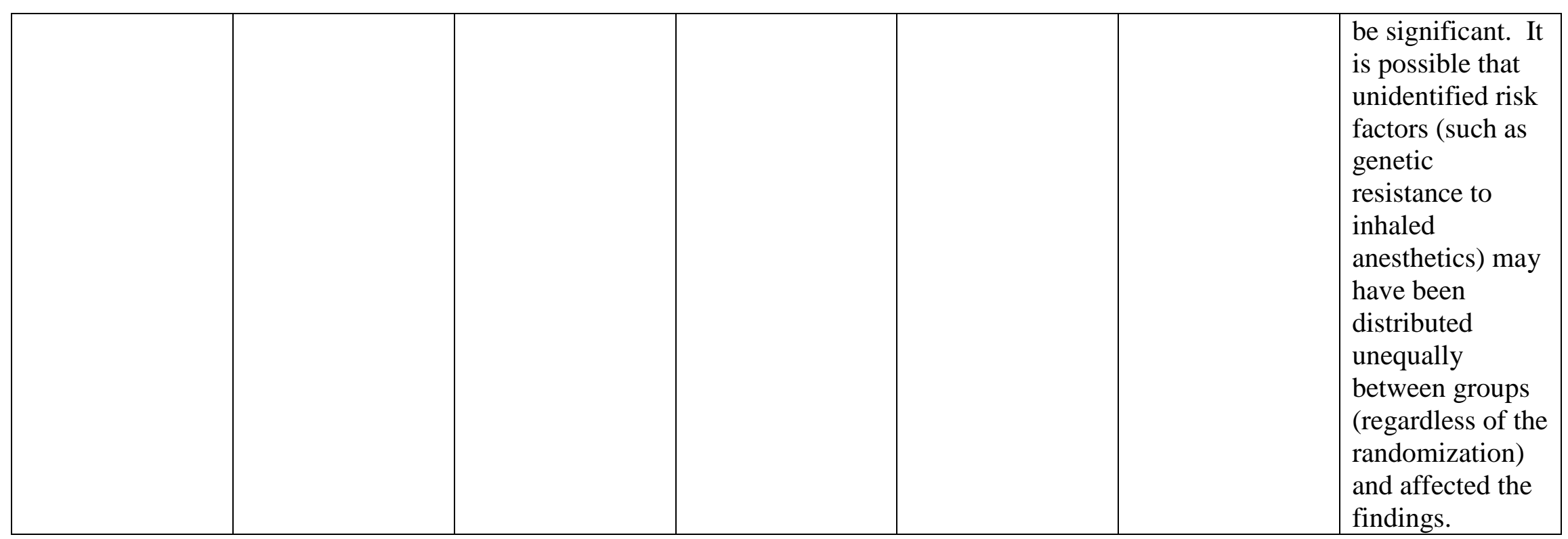


Table B7

Forman, S. (2006). Awareness during general anesthesia: concepts and controversies. Seminars In Anesthesia, Perioperative Medicine \& Pain, 25(4), 211-218.

\begin{tabular}{|c|c|c|c|c|c|c|}
\hline Purpose & Design & Sample & Methods & Data Analysis & Results & Limitations \\
\hline $\begin{array}{l}\text { Describes how } \\
\text { anesthetics work } \\
\text { on different } \\
\text { central nervous } \\
\text { system } \\
\text { functions. } \\
\text { Discusses past } \\
\text { IA studies and } \\
\text { causes that } \\
\text { contributed to it. } \\
\text { Risk factors and } \\
\text { strategies to } \\
\text { prevent IA are } \\
\text { examined. EEG } \\
\text { monitoring } \\
\text { options are } \\
\text { discussed, } \\
\text { particularly BIS, } \\
\text { and results of } \\
\text { studies that have }\end{array}$ & $\begin{array}{l}\text { This was a } \\
\text { literature review } \\
\text { heavily } \\
\text { dependent on } \\
\text { past research. }\end{array}$ & N/A & N/A & $\begin{array}{l}\text { Two studies } \\
\text { were reviewed } \\
\text { and compared. } \\
\text { A study in } \\
\text { Sweden reported } \\
0.06 \% \text { of } \\
\text { patients had } \\
\text { definite } \\
\text { awareness while } \\
\text { a study in the US } \\
\text { produced an } \\
\text { incidence rate of } \\
0.13 \% \text { of } \\
\text { awareness with } \\
\text { recall. Describes } \\
\text { the numerous } \\
\text { uncertainties in } \\
\text { all studies on IA } \\
\text { such as patients } \\
\text { not reporting all }\end{array}$ & $\begin{array}{l}\text { The author } \\
\text { compares MAC, } \\
\text { MAC-BAR, and } \\
\text { MAC-Awake } \\
\text { and describes } \\
\text { how variable } \\
\text { these levels of } \\
\text { anesthesia can be } \\
\text { in patients. He } \\
\text { describes some } \\
\text { of the factors } \\
\text { that can } \\
\text { contribute to } \\
\text { these different } \\
\text { planes of } \\
\text { anesthesia. IA is } \\
\text { described and } \\
\text { how it can vary } \\
\text { from patients } \\
\text { being awake }\end{array}$ & N/A \\
\hline
\end{tabular}




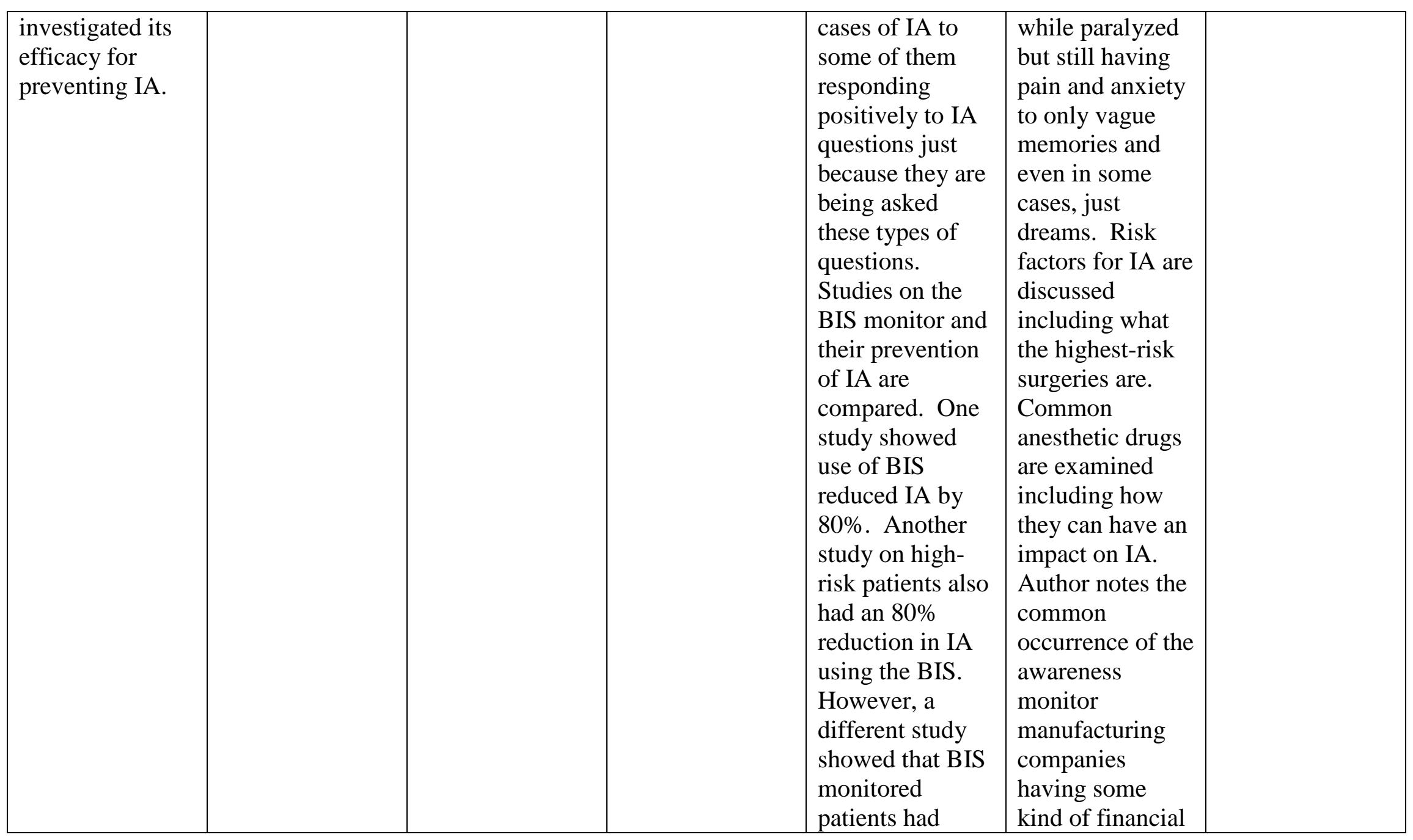




\begin{tabular}{|l|l|l|l|l|}
\hline & & & $\begin{array}{l}\text { higher rates of } \\
\text { IA than those in IA } \\
\text { who had no BIS } \\
\text { monitor. The } \\
\text { author reviews } \\
\text { some of the } \\
\text { flaws in the } \\
\text { trials, which may } \\
\text { have skewed the } \\
\text { results. }\end{array}$ \\
\hline
\end{tabular}


Table B8

Apfelbaum, J.L., Arens, J.F., Cole, D.J., Connis, R. T., Domino, K.B., Drummond,J.C.,...Todd, M.M. (2006). Practice advisory for intraoperative awareness and brain function monitoring: a report by the American society of anesthesiologists task force on intraoperative awareness. Anesthesiology, 104(4), 847-864.

\begin{tabular}{|c|c|c|c|c|c|c|}
\hline Purpose & Design & Sample & Methods & Data Analysis & Results & Limitations \\
\hline $\begin{array}{l}\text { Practice } \\
\text { Advisory } \\
\text { investigated all } \\
\text { of the current } \\
\text { literature and } \\
\text { report opinions } \\
\text { through a variety } \\
\text { of methods. } \\
\text { Task Force } \\
\text { produced a } \\
\text { report for } \\
\text { providers to } \\
\text { assist in decision } \\
\text { making. } \\
\text { Advisory } \\
\text { focused on IA } \\
\text { and brain } \\
\text { function } \\
\text { monitors. }\end{array}$ & $\begin{array}{l}\text { Task force } \\
\text { examined the } \\
\text { current scientific } \\
\text { literature on IA } \\
\text { Sought public } \\
\text { opinion and } \\
\text { additional input } \\
\text { from consultants } \\
\text { who were } \\
\text { knowledgeable } \\
\text { about IA and } \\
\text { brain function } \\
\text { monitors. }\end{array}$ & $\begin{array}{l}\text { Task force was } \\
\text { composed of } 10 \\
\text { members of the } \\
\text { American } \\
\text { Society of } \\
\text { Anesthesiologists } \\
\text { and two } \\
\text { methodologists } \\
\text { from the ASA } \\
\text { Committee on } \\
\text { Practice } \\
\text { Parameters. } \\
\text { Fifty-seven out } \\
\text { of a possible } 95 \\
\text { surveys were } \\
\text { completed and } \\
\text { returned by } \\
\text { consultants. } 151 \\
\text { out of } 500 \\
\text { random ASA }\end{array}$ & $\begin{array}{l}\text { There was a six- } \\
\text { step process in } \\
\text { producing the } \\
\text { advisory. } \\
\text { Members came } \\
\text { to a consensus } \\
\text { on perioperative } \\
\text { interventions to } \\
\text { prevent IA. } \\
\text { Peer-reviewed } \\
\text { journal articles } \\
\text { on IA were } \\
\text { reviewed. } \\
\text { Consultants who } \\
\text { had experience } \\
\text { in IA and } \\
\text { worked in a } \\
\text { variety of } \\
\text { settings } \\
\text { completed }\end{array}$ & $\begin{array}{l}\text { A Pk value of } \\
1.0 \text { indicates } \\
\text { perfect } \\
\text { association } \\
\text { between an } \\
\text { index value and } \\
\text { a clinical state } \\
\text { while a value of } \\
0.50 \text { is indicative } \\
\text { of a chance } \\
\text { prediction } \\
\text { probability. For } \\
\text { the association } \\
\text { between } \\
\text { purposeful } \\
\text { movement and } \\
\text { indicators for } \\
\text { anesthesia depth, } \\
\text { correlational } \\
\text { studies reported }\end{array}$ & $\begin{array}{l}\text { The summary of } \\
\text { the practice } \\
\text { advisory's } \\
\text { recommendations } \\
\text { is listed in } \\
\text { Appendix } 1 \text { in } \\
\text { the article. The } \\
\text { first step is to } \\
\text { perform a } \\
\text { thorough } \\
\text { preoperative } \\
\text { evaluation where } \\
\text { the patient's } \\
\text { medical records } \\
\text { are examined and } \\
\text { potential risk } \\
\text { factors are } \\
\text { investigated. } \\
\text { Next, the } \\
\text { preinduction }\end{array}$ & $\begin{array}{l}2 \text { of the } 10 \\
\text { members of the } \\
\text { Task Force } \\
\text { acknowledged } \\
\text { receiving funds } \\
\text { or having a } \\
\text { financial interest } \\
\text { in brain function } \\
\text { monitor } \\
\text { companies. The } \\
\text { number of } \\
\text { consultants was } \\
\text { even worse as } \\
\text { 54\% } \\
\text { acknowledged } \\
\text { similar financial } \\
\text { interests. The } \\
\text { consultants and } \\
\text { ASA members } \\
\text { who completed }\end{array}$ \\
\hline
\end{tabular}




\begin{tabular}{|c|c|c|c|c|c|c|}
\hline & & $\begin{array}{l}\text { members } \\
\text { completed the } \\
\text { survey. }\end{array}$ & $\begin{array}{l}\text { surveys and } \\
\text { were asked to } \\
\text { comment on a } \\
\text { draft. A random } \\
\text { sample of ASA } \\
\text { members were } \\
\text { asked their } \\
\text { opinion on } \\
\text { relevant issues. } \\
\text { There was an } \\
\text { open forum at } \\
\text { three national } \\
\text { and international } \\
\text { anesthesia } \\
\text { meetings to seek } \\
\text { more input. The } \\
\text { last step was to } \\
\text { integrate all this } \\
\text { information and } \\
\text { come up with a } \\
\text { consensus to } \\
\text { build the actual } \\
\text { practice } \\
\text { advisory. }\end{array}$ & $\begin{array}{l}\text { Pk values } \\
\text { between } 0.74 \\
\text { and } 0.76 \text {. For } \\
\text { using MAP to } \\
\text { decipher } \\
\text { between a } \\
\text { responsive and } \\
\text { unresponsive } \\
\text { state, Pk values } \\
\text { were between } \\
0.68 \text { and } 0.94 \text {. } \\
\text { The Pk values } \\
\text { were between } \\
0.81 \text { to } 0.89 \text { for } \\
\text { using MAP to } \\
\text { distinguish } \\
\text { between an } \\
\text { anesthetized } \\
\text { state and } \\
\text { emergence from } \\
\text { anesthesia. } \\
\text { Instead of MAP, } \\
\text { the Pk values for } \\
\text { heart rate for the } \\
\text { same } 2 \\
\text { comparisons } \\
\text { were between } \\
0.50 \text { and } 0.82\end{array}$ & $\begin{array}{l}\text { phase has a } \\
\text { checklist which } \\
\text { includes making } \\
\text { sure everything is } \\
\text { working properly } \\
\text { from mechanical } \\
\text { equipment to } \\
\text { having proper } \\
\text { anesthetic drugs, } \\
\text { to deciding } \\
\text { whether to use a } \\
\text { benzodiazepine. } \\
\text { Intraoperative } \\
\text { and postoperative } \\
\text { management } \\
\text { strategies are } \\
\text { suggested which } \\
\text { include multiple } \\
\text { methods to } \\
\text { determine if there } \\
\text { is purposeful } \\
\text { movement or } \\
\text { other indicators } \\
\text { that could lead to } \\
\text { IA. These } \\
\text { include vital } \\
\text { signs and } \\
\text { possibly brain }\end{array}$ & $\begin{array}{l}\text { the surveys do } \\
\text { not always agree } \\
\text { on all aspects. } \\
\text { For example, the } \\
\text { consultants do } \\
\text { not believe that } \\
\text { all patients } \\
\text { should be } \\
\text { informed of the } \\
\text { possibility of IA } \\
\text { while the ASA } \\
\text { members are } \\
\text { undecided on } \\
\text { this issue. There } \\
\text { is a similar } \\
\text { discourse when } \\
\text { it comes to the } \\
\text { use of a } \\
\text { benzodiazepine } \\
\text { or scopolamine } \\
\text { as part of an } \\
\text { anesthetic plan } \\
\text { to reduce IA in } \\
\text { all patients. }\end{array}$ \\
\hline
\end{tabular}




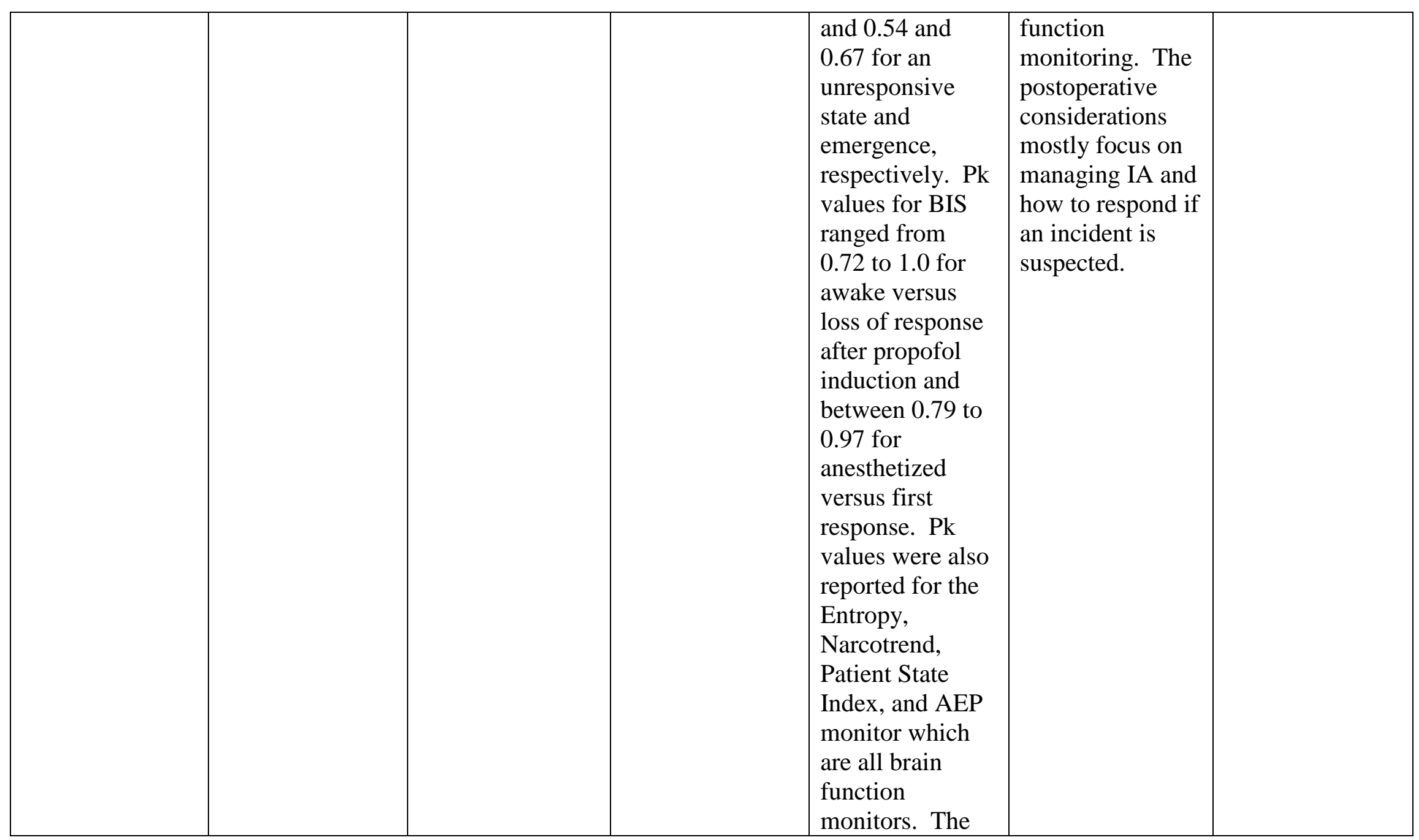




\begin{tabular}{|l|l|l|l|}
\hline & & & advisory used a \\
& & $k$ statistic for \\
rating agreement \\
among the task \\
members and the \\
\end{tabular}


Table B9

Kotsovolis, G., \& Komninos, G. (2009). Awareness during anesthesia: how sure can we be that the patient is sleeping indeed? Hippokratia, 13(2), 83-89.

\begin{tabular}{|c|c|c|c|c|c|c|}
\hline Purpose & Design & Sample & Methods & Data Analysis & Results & Limitations \\
\hline $\begin{array}{l}\text { Authors present } \\
\text { an overview of } \\
\text { IA. They start } \\
\text { by discussing } \\
\text { some of the } \\
\text { manifestations of } \\
\text { IA, how } \\
\text { anesthetic drugs } \\
\text { act on the brain } \\
\text { and central } \\
\text { nervous system, } \\
\text { and what some } \\
\text { of the risk } \\
\text { factors for IA } \\
\text { are. They } \\
\text { proceed to } \\
\text { discuss some of } \\
\text { the methods that } \\
\text { can be used to } \\
\text { estimate depth of }\end{array}$ & $\begin{array}{l}\text { This was a } \\
\text { literature review } \\
\text { which used past } \\
\text { research to } \\
\text { develop their } \\
\text { conclusions. }\end{array}$ & N/A & N/A & N/A & $\begin{array}{l}\text { Although not a } \\
\text { common } \\
\text { incident, IA can } \\
\text { be a very } \\
\text { debilitating } \\
\text { experience and } \\
\text { therefore best to } \\
\text { try and prevent } \\
\text { it. The } \\
\text { preoperative } \\
\text { evaluation is } \\
\text { critical and } \\
\text { ensuring there } \\
\text { are no } \\
\text { mechanical } \\
\text { problems } \\
\text { intraoperatively } \\
\text { as well. Brain } \\
\text { function } \\
\text { monitors are }\end{array}$ & $\begin{array}{l}\text { Insufficient } \\
\text { supporting } \\
\text { information in } \\
\text { declaring the } \\
\text { AEP and } \\
\text { Narcotrend brain } \\
\text { monitors to be } \\
\text { ineffective. }\end{array}$ \\
\hline
\end{tabular}




\begin{tabular}{|l|l|l|l|}
\hline $\begin{array}{l}\text { anesthesia } \\
\text { including brain } \\
\text { function } \\
\text { monitors. }\end{array}$ & & & \\
$\begin{array}{l}\text { Finally, they } \\
\text { discuss some of } \\
\text { the post case } \\
\text { management if } \\
\text { IA does occur. }\end{array}$ & & $\begin{array}{l}\text { available, but the } \\
\text { BIS monitor has } \\
\text { been the only } \\
\text { one shown to be } \\
\text { effective. The } \\
\text { major problem } \\
\text { with BIS is the } \\
\text { cost } \\
\text { effectiveness as } \\
\text { it needs to be } \\
\text { used 138 times } \\
\text { in order to } \\
\text { prevent one } \\
\text { episode of IA. }\end{array}$ \\
\hline
\end{tabular}


Table B10

Castellon-Larios K., Rosero, B.R., Nino-de Mejia, M.C., \& Bergese, S.D. The use of cerebral monitoring for intraoperative awareness. Rev Colomb Anestesiol. 2016;44:23-29.

\begin{tabular}{|c|c|c|c|c|c|c|}
\hline Purpose & Design & Sample & Methods & Data Analysis & Results & Limitations \\
\hline $\begin{array}{l}\text { The purpose of } \\
\text { this study was to } \\
\text { conduct an } \\
\text { analysis on the } \\
\text { pros and cons of } \\
\text { using a BIS } \\
\text { monitor to } \\
\text { manage } \\
\text { anesthesia and to } \\
\text { prevent IA. }\end{array}$ & $\begin{array}{l}\text { This was a } \\
\text { literature review } \\
\text { based on past } \\
\text { studies. }\end{array}$ & N/A & $\begin{array}{l}\text { This was a non- } \\
\text { systematic } \\
\text { review, which } \\
\text { was initiated } \\
\text { with a literature } \\
\text { search in } \\
\text { PubMed where } \\
68 \text { articles were } \\
\text { used after } \\
\text { exclusion } \\
\text { criteria. The } \\
\text { initial search } \\
\text { using keywords } \\
\text { such as “BIS,” } \\
\text { bispectral index } \\
\text { monitoring,” } \\
\text { "recall,” } \\
\text { “intraoperative } \\
\text { awareness,” and } \\
\text { a few more } \\
\text { returned 2,526 }\end{array}$ & $\begin{array}{l}\text { From previous } \\
\text { studies, the } \\
\text { authors did } \\
\text { identify some } \\
\text { data analysis that } \\
\text { was performed. } \\
\text { One meta- } \\
\text { analysis showed } \\
\text { that BIS reduced } \\
\text { IA by 65.4\%. } \\
\text { Another study } \\
\text { analyzed cases } \\
\text { of IA and } \\
\text { indicated that } \\
\text { 47\% occurred } \\
\text { during } \\
\text { anesthesia } \\
\text { induction, 30\% } \\
\text { during surgery, } \\
\text { and 23\% before } \\
\text { recovery. }\end{array}$ & $\begin{array}{l}\text { Based on past } \\
\text { studies the } \\
\text { authors analyzed, } \\
\text { they concluded } \\
\text { BIS guided } \\
\text { anesthesia helps } \\
\text { prevent IA along } \\
\text { with } \\
\text { postoperative } \\
\text { nausea/vomiting, } \\
\text { pain, and } \\
\text { delirium. Authors } \\
\text { had several } \\
\text { recommendations } \\
\text { to reduce the } \\
\text { possibility of IA. } \\
\text { These included } \\
\text { pre-medicating } \\
\text { with drugs that } \\
\text { have a sedative } \\
\text { effect }\end{array}$ & $\begin{array}{l}\text { The review did } \\
\text { not mention any } \\
\text { study that } \\
\text { showed BIS did } \\
\text { not have a } \\
\text { reduction in IA. }\end{array}$ \\
\hline
\end{tabular}




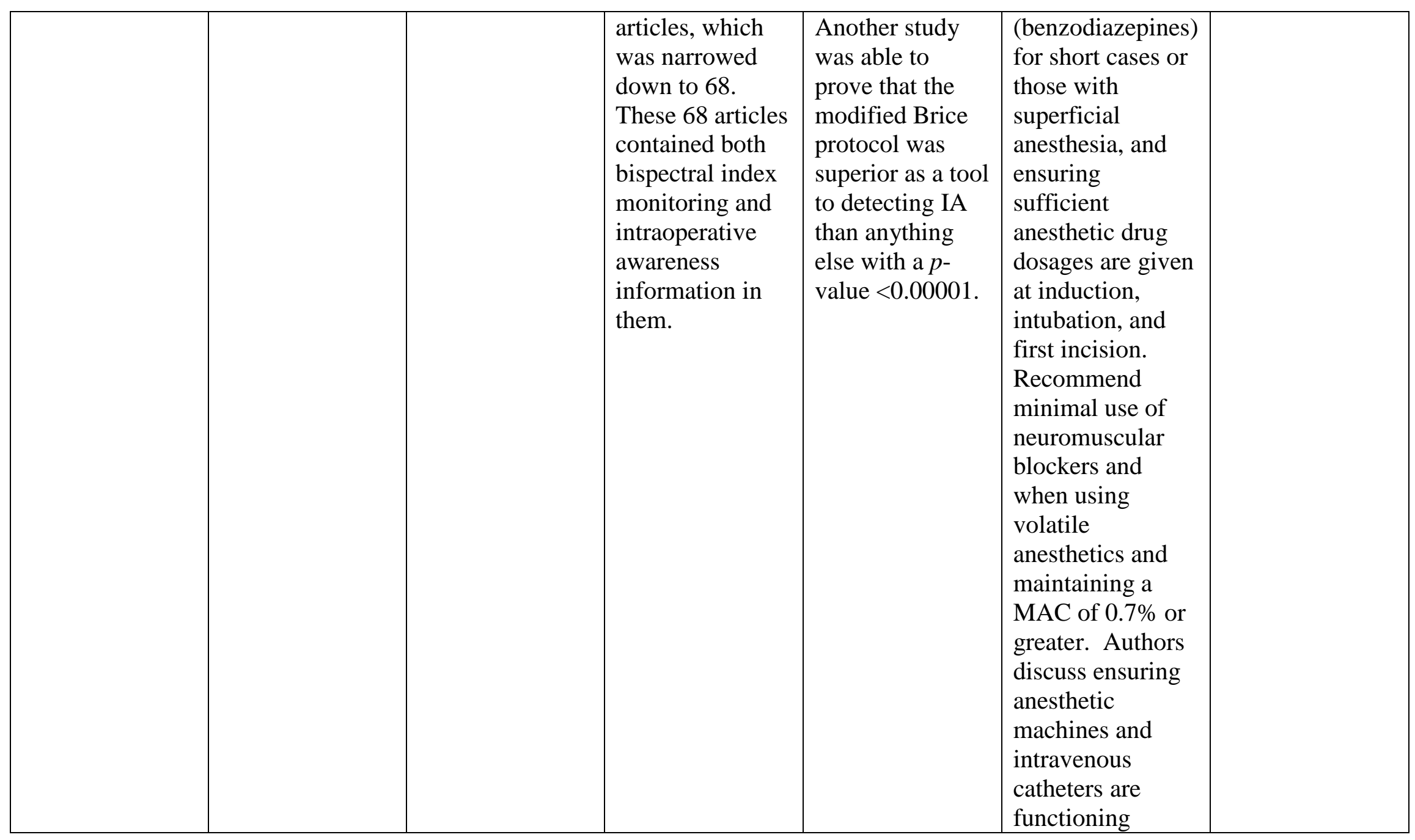




\begin{tabular}{|l|l|l|l|l|}
\hline & & & & properly and for \\
patients with IA \\
risk factors, the \\
possibility of IA \\
should be \\
discussed.
\end{tabular}




\section{Appendix C}

\section{Guide to an Overall Critique of a Quantitative Research Report}

Table C1

Ekman, A., Lindholm, M., Lennmarken, C., \& Sandin, R. (2004). Reduction in the incidence of awareness using BIS monitoring. Acta Anaesthesiologica Scandinavica, 48(1), 20-26.

\begin{tabular}{|c|c|c|}
\hline Aspect of the Report & Critiquing Questions & Detailed Critiquing Guidelines \\
\hline Title & $\begin{array}{l}\text { - Is the title a good one, succinctly suggesting key } \\
\text { variables and the study population? }\end{array}$ & $\begin{array}{l}\text { Gives some information regarding study; } \\
\text { does not give any details about study } \\
\text { population or key variables. }\end{array}$ \\
\hline Abstract & $\begin{array}{l}\text { - Did the abstract clearly and concisely summarize the } \\
\text { main features of the report (problem, methods, } \\
\text { results, conclusions)? }\end{array}$ & $\begin{array}{l}\text { Yes, abstract contained all pertinent sections } \\
\text { of study with clarity. }\end{array}$ \\
\hline $\begin{array}{l}\text { Introduction } \\
\text { Statement of the } \\
\text { problem }\end{array}$ & $\begin{array}{l}\text { - Was the problem stated unambiguously, and was it } \\
\text { easy to identify? } \\
\text { - Is the problem statement build a persuasive argument } \\
\text { for the new study? } \\
\text { - Was there a good match between the research } \\
\text { problem and the methods used -that is, was a } \\
\text { quantitative approach appropriate? }\end{array}$ & $\begin{array}{l}\text { Problem statement sets the argument for the } \\
\text { study but is somewhat lacking in detail in } \\
\text { regard to the problem of explicit recall (i.e. } \\
\text { awareness). The match between research } \\
\text { problem and methods was good. Study used } \\
\text { a modified Brice interview at three distinct } \\
\text { times after the surgery and conducted a more } \\
\text { in-depth interview for any patient who } \\
\text { remembered something between falling } \\
\text { asleep and waking up. }\end{array}$ \\
\hline
\end{tabular}




\begin{tabular}{|c|c|c|}
\hline $\begin{array}{l}\text { Hypotheses or } \\
\text { research questions }\end{array}$ & $\begin{array}{l}\text { - Were research questions and/or hypotheses explicitly } \\
\text { stated? If not, was their absence justified? } \\
\text { - Were questions and hypotheses appropriately } \\
\text { worded, with clear specification of key variables and } \\
\text { the study population? } \\
\text { - Were the questions/hypotheses consistent with } \\
\text { existing knowledge? }\end{array}$ & $\begin{array}{l}\text { Research question explicitly stated: Did the } \\
\text { introduction of routine clinical } \\
\text { neurophysiological monitoring using the BIS } \\
\text { A-200 monitor have any effect on the } \\
\text { incidence of awareness? Key } \\
\text { variables/population identified (16 and older } \\
\text { patients undergoing surgery requiring } \\
\text { muscle relaxants or intubation, along with } \\
\text { maintaining BIS values between } 40-60 \text { as } \\
\text { much as possible and to definitely avoid } \\
\text { values }>60) \text {. }\end{array}$ \\
\hline Literature review & $\begin{array}{l}\text { - Was the literature review up-to-date and based } \\
\text { mainly on primary sources? } \\
\text { - Did the review provide a state-of-the-art synthesis of } \\
\text { evidence on the problem? } \\
\text { - Did the literature review provide a strong basis for } \\
\text { the new study? }\end{array}$ & $\begin{array}{l}\text { No literature review in the study. Study did } \\
\text { not provide any context for a new synthesis } \\
\text { of evidence on the problem of awareness. }\end{array}$ \\
\hline
\end{tabular}

\section{Guide to an Overall Critique of a Quantitative Research Report}

\section{Aspect of the Report Critiquing Questions \\ Detailed Critiquing Guidelines}

Conceptual/theoretical framework
- Were key concepts adequately defined conceptually?

- Was a conceptual/theoretical framework articulated-and, if so, was it appropriate? If not, is
Although a theoretical framework was not included in the study, critical key concepts adequately defined. Although not entirely 


\begin{tabular}{|c|c|c|}
\hline & $\begin{array}{l}\text { the absence of a framework justified? } \\
\text { - Were the questions/hypotheses consistent with the } \\
\text { framework? }\end{array}$ & $\begin{array}{l}\text { justified, lack of framework is somewhat } \\
\text { commonplace for these types of quantitative } \\
\text { studies. }\end{array}$ \\
\hline $\begin{array}{l}\text { Method } \\
\text { Protection of human } \\
\text { rights }\end{array}$ & $\begin{array}{l}\text { - Were appropriate procedures used to safe-guard the } \\
\text { rights of study participants? } \\
\text { - Was the study externally reviewed by an IRB/ethics } \\
\text { review board? } \\
\text { - Was the study designed to minimize risks and } \\
\text { maximize benefits to participants? }\end{array}$ & $\begin{array}{l}\text { It is difficult to determine the level of } \\
\text { protection of rights that were afforded the } \\
\text { participants. Although the study itself was } \\
\text { IRB approved, there was no description of } \\
\text { what rights the patients had in terms of the } \\
\text { study. Study described } 66 \text { patients that were } \\
\text { excluded either due to poor quality or } \\
\text { discontinuous trends or failure to conduct } \\
\text { any of the last two interviews for awareness. } \\
\text { Study designed to prevent awareness by } \\
\text { following the manufacturer suggested BIS } \\
\text { levels of } 40-60 \text { during induction and } \\
\text { maintenance. }\end{array}$ \\
\hline Research design & $\begin{array}{l}\text { - Was the most rigorous design used, given the study } \\
\text { purpose? } \\
\text { - Were appropriate comparisons made to enhance } \\
\text { interpretability of the findings? } \\
\text { - Was the number of data collection points } \\
\text { appropriate? } \\
\text { Did the design minimize biases and threats to the } \\
\text { internal, construct, and external validity of the study } \\
\text { (e.g., was blinding used, was attrition minimized)? }\end{array}$ & $\begin{array}{l}\text { As this was a prospective, historical, } \\
\text { controlled, cohort trial and not a randomized } \\
\text { study, it was not the most rigorous design } \\
\text { given the study purpose. It is unclear if the } \\
\text { number of data collection points were } \\
\text { appropriate. They compared 4,945 BIS } \\
\text { monitored patients with 7,826 non-BIS } \\
\text { monitored patients. Although, statistically } \\
\text { significant results in the prevention of IA }\end{array}$ \\
\hline
\end{tabular}




\begin{tabular}{|c|c|c|}
\hline & & $\begin{array}{l}\text { were obtained, there was no discussion of } \\
\text { the appropriateness of using } 4,945 \text { and } 7,826 \\
\text { patients. Study acknowledged some validity } \\
\text { concerns in that knowledge of the study of } \\
\text { the BIS monitor may have influenced some } \\
\text { parts of clinical practice. There was also } \\
\text { some significant potential bias as the BIS } \\
\text { manufacturer provided a grant for this study. } \\
\text { BIS and non-BIS groups were very similar } \\
\text { in demographic breakdown. Some clinical } \\
\text { significance in the increased availability of } \\
\text { end-tidal gas monitoring in the BIS group } \\
\text { (99\% vs } 80 \% \text { ). Authors acknowledge that } \\
\text { this may have had an impact. }\end{array}$ \\
\hline Population and sample & $\begin{array}{l}\text { - Was the population identified? Was the sample } \\
\text { described in sufficient detail? } \\
\text { - Was the best possible sampling design used to } \\
\text { enhance the sample's representativeness? Were } \\
\text { sampling biases minimized? } \\
\text { - Was the sample size based on a power analysis? }\end{array}$ & $\begin{array}{l}\text { Aside from possibly including a comparison } \\
\text { of the actual surgical procedures used for } \\
\text { both groups, the population was identified } \\
\text { and with sufficient detail in study's Table } 1 \text {. } \\
\text { Sampling biases minimized as the key } \\
\text { demographics between the BIS and non-BIS } \\
\text { group had high degrees of correlation. No } \\
\text { power analysis to determine sample size. }\end{array}$ \\
\hline
\end{tabular}




\section{Guide to an Overall Critique of a Quantitative Research Report}

\begin{tabular}{|c|c|c|}
\hline Aspect of the Report & Critiquing Questions & Detailed Critiquing Guidelines \\
\hline $\begin{array}{l}\text { Data collection and } \\
\text { measurement }\end{array}$ & $\begin{array}{l}\text { - Were the operational and conceptual definitions } \\
\text { congruent? } \\
\text { - Were key variables measured using an appropriate } \\
\text { method (e.g., interviews, observations, and so on)? } \\
\text { Were specific instruments adequately described and } \\
\text { were they good choices, given the study population } \\
\text { and the variables being studied? } \\
\text { Did the report provide evidence that the data } \\
\text { collection methods yielded data that were reliable, } \\
\text { valid and responsive? }\end{array}$ & $\begin{array}{l}\text { Operational and conceptual definitions were } \\
\text { congruent. Appropriate method (interview) } \\
\text { used to measure key variable being } \\
\text { investigated. Modified Brice interview used } \\
\text { for initial investigation into whether } \\
\text { awareness occurred and is an appropriate } \\
\text { instrument. No description of the more in- } \\
\text { depth follow-up interview used when patient } \\
\text { possibly had awareness. No discussion that } \\
20 \text { patients indicated remembering } \\
\text { something but only } 2 \text { actually described } \\
\text { cases suggestive of awareness. Would have } \\
\text { been beneficial to see some examples of why } \\
\text { the other } 18 \text { patients were not included as } \\
\text { cases of awareness. }\end{array}$ \\
\hline Procedures & $\begin{array}{l}\text { - If there was an intervention, was it adequately } \\
\text { described, and was it rigorously developed and } \\
\text { implemented? Did most participants allocated to the } \\
\text { intervention group actually receive it? Was there } \\
\text { evidence of intervention fidelity? } \\
\text { - Were data collected in a manner that minimized bias? } \\
\text { Were the staff who collected data appropriately } \\
\text { trained? }\end{array}$ & $\begin{array}{l}\text { Intervention of BIS adequately described, } \\
\text { and anesthesia providers received training } \\
\text { and information regarding its use. 4,945 out } \\
\text { of 5,057 possible patients utilized BIS; } \\
\text { indicates a high level of intervention fidelity. } \\
\text { Again, it is possible that bias occurred if } \\
\text { knowledge of the study of the BIS monitor }\end{array}$ \\
\hline
\end{tabular}




\begin{tabular}{|c|c|c|}
\hline & & occurred amongst staff. \\
\hline Data Analysis & $\begin{array}{l}\text { - Were analyses undertaken to address each research } \\
\text { - } \text { Wuestion or test each hypothesis? } \\
\text { level of measurement of the variables, number of } \\
\text { groups being compared, and assumptions of the } \\
\text { texts? } \\
\text { - Was a powerful analytic method used? (e.g., did the } \\
\text { analysis help to control for confounding variables)? } \\
\text { - Were type I and Type II errors avoided or } \\
\text { minimized? } \\
\text { In intervention studies, was an intention-to-treat } \\
\text { analysis performed? }\end{array}$ & $\begin{array}{l}\text { As there was only one research question } \\
\text { being studied, there was an analysis done } \\
\text { regarding the rate of IA. Appropriate } \\
\text { statistical methods were used (Student's t- } \\
\text { test, double-sided, or the Chi-square with } \\
\text { Yate's correction). Type I and II errors were } \\
\text { not mentioned. Analyses were performed on } \\
\text { an intention-to-treat basis based on whether } \\
\text { BIS had been used. }\end{array}$ \\
\hline
\end{tabular}

\section{Guide to an Overall Critique of a Quantitative Research Report}

\begin{tabular}{|l|l|l|}
\multicolumn{1}{c|}{$\begin{array}{c}\text { Aspect of the } \\
\text { Report }\end{array}$} & \multicolumn{1}{c|}{ Critiquing Questions } & \multicolumn{1}{c|}{ Detailed Critiquing Guidelines } \\
\hline $\begin{array}{l}\text { Data Analysis } \\
\text { (continued) }\end{array}$ & $\begin{array}{l}\text { Were problems of missing values evaluated and } \\
\text { adequately addressed? }\end{array}$ & $\begin{array}{l}\text { Missing values were addressed and evaluated. } \\
\text { Although } 112 \text { patients were excluded from } \\
\text { the study for various reasons, none of these } \\
\text { patients had reports of awareness. }\end{array}$ \\
\hline Findings & $\bullet \begin{array}{l}\text { Was information about statistical significance } \\
\text { presented? Was information about effect size and } \\
\text { precision of estimates (confidence intervals) } \\
\text { presented? }\end{array}$ & $\begin{array}{l}\text { The number of awareness events in the BIS- } \\
\text { group was statistically significantly and fewer } \\
\text { than the historical control group. As } \\
\text { determined by Fischer's exact test, it }\end{array}$ \\
\hline
\end{tabular}




\begin{tabular}{|c|c|c|}
\hline & $\begin{array}{l}\text { - Were the findings adequately summarized, with good } \\
\text { use of tables and figures? } \\
\text { Were findings reported in a manner that facilitates a } \\
\text { meta-analysis, and with sufficient information } \\
\text { needed for EBP? }\end{array}$ & $\begin{array}{l}\text { produced a } p \text {-value of } 0.019 \text { for the single } \\
\text { sided and } p \text {-value of } 0.038 \text { in the double- } \\
\text { sided test. This was a } 77 \% \text { reduction in } \\
\text { awareness rate for the BIS group. No } \\
\text { mention of confidence intervals and effect } \\
\text { size. Tables and figures were adequately } \\
\text { presented but additional information could } \\
\text { have been displayed. This includes what was } \\
\text { asked during the in-depth follow-up } \\
\text { interviews of those who had awareness as } \\
\text { well as what was some of the content of } \\
\text { things that were claimed to have been } \\
\text { remembered but were then rejected by the } \\
\text { study authors. Due to some of the limitations } \\
\text { reported, not sufficient information for EBP. }\end{array}$ \\
\hline $\begin{array}{l}\text { Discussion } \\
\text { Interpretation of the } \\
\text { findings }\end{array}$ & $\begin{array}{l}\text { - Were all major findings interpreted and discussed } \\
\text { within the context of prior research and/or the } \\
\text { study’s conceptual framework? } \\
\text { - Were casual inferences, if any, justified? } \\
\text { - Was the issue of clinical significance discussed? } \\
\text { - Were interpretations well-founded and consistent } \\
\text { with the study's limitations? } \\
\text { - Did the report address the issue of the } \\
\text { generalizability of the findings? }\end{array}$ & $\begin{array}{l}\text { Only one mention of previous research when } \\
\text { the findings were discussed. Authors } \\
\text { compared their results with a previous } \\
\text { prospective, randomized study. Some } \\
\text { discussion of clinical significance of results } \\
\text { and the interpretations were consistent with } \\
\text { the limitations of the study. The authors' } \\
\text { conclusions did indicate that their results } \\
\text { could be generalized to the population as a } \\
\text { whole. }\end{array}$ \\
\hline
\end{tabular}




\begin{tabular}{|l|l|l|}
\hline $\begin{array}{l}\text { Implications/ } \\
\text { recommendations }\end{array}$ & $\begin{array}{l}\text { Did the researchers discuss the implications of the } \\
\text { study for clinical practice or further research-and } \\
\text { were those implications reasonable and complete? }\end{array}$ & $\begin{array}{l}\text { Researchers suggested BIS use associated } \\
\text { with a significantly reduced incidence of } \\
\text { awareness. Did not mention anything } \\
\text { regarding further research. Although the } \\
\text { implications may seem reasonable to the } \\
\text { author, should probably be more research and } \\
\text { data before coming to such a conclusion. }\end{array}$ \\
\hline $\begin{array}{l}\text { General Issues } \\
\text { Presentation }\end{array}$ & $\bullet \begin{array}{l}\text { Was the report well-written, organized, and } \\
\text { sufficiently detailed for critical analysis? } \\
\text { In intervention studies, was a CONSORT flowchart } \\
\text { provided to show the flow of participants in the } \\
\text { study? }\end{array}$ & $\begin{array}{l}\text { Report was adequately written and organized. } \\
\text { Could have been additional details included } \\
\text { in the study and additional statistical analysis. } \\
\text { A flowchart was not utilized in the study } \\
\text { showing the flow of participants. }\end{array}$ \\
\hline
\end{tabular}

\section{Guide to an Overall Critique of a Quantitative Research Report}

\begin{tabular}{|c|c|c|}
\hline $\begin{array}{l}\text { Aspect of the } \\
\text { Report }\end{array}$ & Critiquing Questions & Detailed Critiquing Guidelines \\
\hline $\begin{array}{l}\text { General Issues } \\
\text { Presentation } \\
\text { (continued) }\end{array}$ & $\begin{array}{l}\text { - Was the report written in a manner that makes the } \\
\text { findings accessible to practicing nurses? }\end{array}$ & $\begin{array}{l}\text { Report is written that makes the findings } \\
\text { accessible to those practicing anesthesia. }\end{array}$ \\
\hline $\begin{array}{l}\text { Researcher } \\
\text { credibility }\end{array}$ & $\begin{array}{l}\text { Do the researchers' clinical, substantive, or } \\
\text { methodologic qualifications and experience enhance } \\
\text { confidence in the findings and their interpretation? }\end{array}$ & $\begin{array}{l}\text { Not much mention of the researchers' } \\
\text { qualifications and experience. } \\
\text { Acknowledged the manufacturer of the BIS } \\
\text { monitoring system provided a grant to aid in } \\
\text { this study. }\end{array}$ \\
\hline
\end{tabular}




\begin{tabular}{|c|c|c|}
\hline $\begin{array}{l}\text { Summary } \\
\text { assessment }\end{array}$ & $\begin{array}{l}\text { Despite any limitations, do the study findings appear } \\
\text { to be valid-do you have confidence in the truth } \\
\text { value of the results? } \\
\text { - Does the study contribute any meaningful evidence } \\
\text { that can be used in nursing practice or that is useful } \\
\text { to the nursing discipline? }\end{array}$ & $\begin{array}{l}\text { Findings appear to be valid and no reason to } \\
\text { doubt this. However, to assume that their } \\
\text { conclusion is valid based solely on their study } \\
\text { would definitely seem to be short-sighted. } \\
\text { By itself, the study does not seem to } \\
\text { contribute moving evidence of their } \\
\text { conclusion, but if taken together with other } \\
\text { studies that were able to replicate and had } \\
\text { similar results, could potentially be shown to } \\
\text { be useful to the anesthesia discipline. }\end{array}$ \\
\hline
\end{tabular}

*Reprinted with permission from the editor of D. Polit and C. Beck (2017). Nursing Research. Generating and assessing evidence for nursing practice $\left(10^{\text {th }}\right.$ ed.). Wolters Kluwer. 


\section{Guide to an Overall Critique of a Quantitative Research Report}

Table C2

Avidan, M., Zhang ,L., Burnside, B., Finkel, K., Searleman, A., Selvidge, J., Saager, L., Turner, M.T., Rao, S., Bottros, M., Hantler, C., Jacobsohn, E., \& Evers, A. (2008). Anesthesia awareness and the bispectral index. New England Journal of Medicine, 358(11), 1097-1108.

\begin{tabular}{|c|c|c|}
\hline $\begin{array}{l}\text { Aspect of the } \\
\text { Report }\end{array}$ & Critiquing Questions & Detailed Critiquing Guidelines \\
\hline Title & $\begin{array}{l}\text { - Is the title a good one, succinctly suggesting key } \\
\text { variables and the study population? }\end{array}$ & $\begin{array}{l}\text { The title is appropriate and gives instant } \\
\text { information. Does not identify study } \\
\text { population; it gives the key variable of what } \\
\text { is being studied. }\end{array}$ \\
\hline Abstract & $\begin{array}{l}\text { Did the abstract clearly and concisely summarize the } \\
\text { main features of the report (problem, methods, } \\
\text { results, conclusions)? }\end{array}$ & $\begin{array}{l}\text { Abstract comprehensive. Gave information } \\
\text { regarding awareness during anesthesia and } \\
\text { information about BIS and how it is used. } \\
\text { Abstract brief but succinct, states methods } \\
\text { used and results and conclusions. }\end{array}$ \\
\hline $\begin{array}{l}\text { Introduction } \\
\text { Statement of the } \\
\text { problem }\end{array}$ & $\begin{array}{l}\text { - Was the problem stated unambiguously, and was it } \\
\text { easy to identify? } \\
\text { - Is the problem statement build a persuasive argument } \\
\text { for the new study? } \\
\text { - Was there a good match between the research } \\
\text { problem and the methods used -that is, was a } \\
\text { quantitative approach appropriate? }\end{array}$ & $\begin{array}{l}\text { Problem of anesthesia awareness described } \\
\text { clearly with potential problems. Problem } \\
\text { statement intends to further a prior study’s } \\
\text { results that showed a reduction in awareness } \\
\text { with BIS, but compared it with another } \\
\text { intervention, maintaining a certain end-tidal } \\
\text { anesthetic gas (ETAG) concentration. There }\end{array}$ \\
\hline
\end{tabular}




\begin{tabular}{|c|c|c|}
\hline & & $\begin{array}{l}\text { is an excellent match between the problem } \\
\text { and the methods. Quantitative problem and } \\
\text { study utilized quantitative methods. }\end{array}$ \\
\hline $\begin{array}{l}\text { Hypotheses or } \\
\text { research questions }\end{array}$ & $\begin{array}{l}\text { - Were research questions and/or hypotheses explicitly } \\
\text { stated? If not, was their absence justified? } \\
\text { - Were questions and hypotheses appropriately } \\
\text { worded, with clear specification of key variables and } \\
\text { the study population? } \\
\text { - Were the questions/hypotheses consistent with } \\
\text { existing knowledge? }\end{array}$ & $\begin{array}{l}\text { Hypothesis clearly stated in abstract. } \\
\text { Analyzed if the incidence of anesthesia } \\
\text { awareness in high-risk patients would be } \\
\text { reduced in a BIS-guided protocol as } \\
\text { compared to an ETAG-guided protocol. } \\
\text { Key variables, in terms of what constituted } \\
\text { high-risk patients, were clearly defined as } \\
\text { was the study population. Hypothesis from } \\
\text { a prior study was modified in an attempt } \\
\text { replicate results. }\end{array}$ \\
\hline Literature review & $\begin{array}{l}\text { - Was the literature review up-to-date and based } \\
\text { mainly on primary sources? } \\
\text { Did the review provide a state-of-the-art synthesis of } \\
\text { evidence on the problem? } \\
\text { - Did the literature review provide a strong basis for } \\
\text { the new study? }\end{array}$ & $\begin{array}{l}\text { No specific literature review section, but the } \\
\text { study they tried to modify (B-Aware study) } \\
\text { was current (2004) and it was a primary } \\
\text { source. All references cited except one were } \\
\text { published within the last } 15 \text { years of this } \\
\text { article. }\end{array}$ \\
\hline
\end{tabular}

\section{Guide to an Overall Critique of a Quantitative Research Report}

\section{Aspect of the Report} Critiquing Questions

Detailed Critiquing Guidelines

Conceptual/theoretical

- Were key concepts adequately defined conceptually?

No theoretical framework described. As it is 


\begin{tabular}{|c|c|c|}
\hline framework & $\begin{array}{l}\text { - Was a conceptual/theoretical framework } \\
\text { articulated-and, if so, was it appropriate? If not, is } \\
\text { the absence of a framework justified? } \\
\text { - Were the questions/hypotheses consistent with the } \\
\text { framework? }\end{array}$ & $\begin{array}{l}\text { an interventional comparison, the absence of } \\
\text { a framework is acceptable. Key concepts of } \\
\text { awareness during anesthesia as well as the } \\
\text { vehicle for detecting it are described in } \\
\text { detail. }\end{array}$ \\
\hline $\begin{array}{l}\text { Method } \\
\text { Protection of human } \\
\text { rights }\end{array}$ & $\begin{array}{l}\text { - Were appropriate procedures used to safe-guard the } \\
\text { rights of study participants? } \\
\text { - Was the study externally reviewed by an IRB/ethics } \\
\text { review board? } \\
\text { - Was the study designed to minimize risks and } \\
\text { maximize benefits to participants? }\end{array}$ & $\begin{array}{l}\text { Study approved by the Washington } \\
\text { University Human Research Protection } \\
\text { Office and followed the Consolidated } \\
\text { Standards of Reporting Trial guidelines. } \\
\text { Although not approved by an IRB or ethics } \\
\text { board, probably safe to assume the rights of } \\
\text { study participants were protected. Study } \\
\text { seemed to try to minimize risks as there were } \\
\text { no guidelines for anesthesia plans; there was } \\
\text { randomization of the study patients. Authors } \\
\text { tried to maximize benefits by offering any } \\
\text { patient who had possible memories or signs } \\
\text { of awareness a referral for counseling. }\end{array}$ \\
\hline Research design & $\begin{array}{l}\text { - Was the most rigorous design used, given the study } \\
\text { - Wurpose? } \\
\text { - Were appropriate comparisons made to enhance } \\
\text { interpretability of the findings? } \\
\text { - Was the number of data collection points } \\
\text { appropriate? } \\
\text { internal, construct, and external validity of the study }\end{array}$ & $\begin{array}{l}\text { Study design was fairly rigorous; was a } \\
\text { prospective study and included } \\
\text { randomization. Anesthesia providers were } \\
\text { aware of the patient’s group assignment, but } \\
\text { no one else in the study had this knowledge. } \\
\text { Comparisons of the two groups revealed } \\
\text { very similar demographics except for one }\end{array}$ \\
\hline
\end{tabular}




\begin{tabular}{|c|c|c|}
\hline & (e.g., was blinding used, was attrition minimized)? & $\begin{array}{l}\text { aspect (significantly more patients with } \\
\text { neurologic disease in the ETAG group than } \\
\text { in the BIS group). Based on their statistical } \\
\text { analysis, the number of data collection } \\
\text { points was appropriate. Design of the study } \\
\text { minimized biases to a certain extent. There } \\
\text { was randomization, blinding (except for the } \\
\text { anesthesia provider) to the data, and attrition } \\
\text { was certainly minimized with reasons given } \\
\text { for those who did not participate in the } \\
\text { study. Authors acknowledged limitations, } \\
\text { namely the subjectivity of awareness and the } \\
\text { questions themselves may produce false } \\
\text { memories. }\end{array}$ \\
\hline $\begin{array}{l}\text { Population and } \\
\text { sample }\end{array}$ & $\begin{array}{l}\text { Was the population identified? Was the sample } \\
\text { described in sufficient detail? } \\
\text { - Was the best possible sampling design used to } \\
\text { enhance the sample’s representativeness? Were } \\
\text { sampling biases minimized? } \\
\text { - Was the sample size based on a power analysis? }\end{array}$ & $\begin{array}{l}\text { Study population was described in sufficient } \\
\text { detail with all significant characteristics } \\
\text { identified. Study conducted with simple } \\
\text { random sampling. Sampling design very } \\
\text { detailed - groups equivalent in overall } \\
\text { demographics (except for neurologic } \\
\text { disease). Since this study was looking at } \\
\text { high-risk patients, the criteria needed were } \\
\text { very specific. This definitely helped to } \\
\text { minimize biases along with randomization. } \\
\text { Sample size was based on a power analysis. }\end{array}$ \\
\hline
\end{tabular}




\section{Guide to an Overall Critique of a Quantitative Research Report}

\begin{tabular}{|c|c|c|}
\hline Aspect of the Report & Critiquing Questions & Detailed Critiquing Guidelines \\
\hline $\begin{array}{l}\text { Data collection and } \\
\text { measurement }\end{array}$ & $\begin{array}{l}\text { - Were the operational and conceptual definitions } \\
\text { congruent? } \\
\text { - Were key variables measured using an appropriate } \\
\text { method (e.g., interviews, observations, and so on)? } \\
\text { - Were specific instruments adequately described and } \\
\text { were they good choices, given the study population } \\
\text { and the variables being studied? } \\
\text { - Did the report provide evidence that the data } \\
\text { collection methods yielded data that were reliable, } \\
\text { valid and responsive? }\end{array}$ & $\begin{array}{l}\text { Conceptual definition was awareness during } \\
\text { anesthesia while the operational definition } \\
\text { was obtained using the Brice questionnaire. } \\
\text { Key variables were obtained by the } \\
\text { questionnaire and for those with awareness, } \\
\text { their data was cross-referenced with either } \\
\text { their BIS or ETAG readings. Although the } \\
\text { Brice questionnaire was not described in } \\
\text { detail, its contents can easily be found online } \\
\text { and it is a very suitable instrument to use for } \\
\text { this type of study. The way the data was } \\
\text { analyzed by at least three different experts in } \\
\text { order to come to a consensus about whether } \\
\text { an event was true awareness was a strong } \\
\text { data collection method and helped ensure } \\
\text { validity. The vast majority of study } \\
\text { participants finish all three interviews which } \\
\text { strengthened the data. }\end{array}$ \\
\hline Procedures & $\begin{array}{l}\text { - If there was an intervention, was it adequately } \\
\text { described, and was it rigorously developed and } \\
\text { implemented? Did most participants allocated to the } \\
\text { intervention group actually receive it? Was there } \\
\text { evidence of intervention fidelity? }\end{array}$ & $\begin{array}{l}\text { Intervention was either use or no use of the } \\
\text { BIS monitor. BIS described in detail and the } \\
\text { range of values targeted. BIS group had } 33 \\
\text { exclusions and the ETAG group } 26 \\
\text { exclusions for various legitimate reasons }\end{array}$ \\
\hline
\end{tabular}




\begin{tabular}{|c|c|c|}
\hline & $\begin{array}{l}\text { - Were data collected in a manner that minimized bias? } \\
\text { Were the staff who collected data appropriately } \\
\text { trained? }\end{array}$ & $\begin{array}{l}\text { (cancellation of surgery, handful of } \\
\text { omissions due to technical reasons, or a } \\
\text { change in the proposed anesthetic plan). } \\
\text { Remaining patients in each group received } \\
\text { intended intervention. There was } \\
\text { intervention fidelity as } 96.7 \% \text { and } 97.4 \% \\
\text { received the designated intervention of BIS } \\
\text { or ETAG, respectively. Data was obtained } \\
\text { in ways that certainly minimized bias. Aside } \\
\text { from the anesthesia provider, the patients, } \\
\text { postoperative interviewers, expert reviewers, } \\
\text { and statistician did not have knowledge, } \\
\text { which group participants belonged to. No } \\
\text { other description of the staff or how they } \\
\text { were trained. }\end{array}$ \\
\hline Data Analysis & $\begin{array}{l}\text { - Were analyses undertaken to address each research } \\
\text { question or test each hypothesis? } \\
\text { - Were appropriate statistical methods used, given the } \\
\text { level of measurement of the variables, number of } \\
\text { groups being compared, and assumptions of the } \\
\text { texts? } \\
\text { - Was a powerful analytic method used? (e.g., did the } \\
\text { analysis help to control for confounding variables)? } \\
\text { Were type I and Type II errors avoided or } \\
\text { minimized? } \\
\text { In intervention studies, was an intention-to-treat } \\
\text { analysis performed? }\end{array}$ & $\begin{array}{l}\text { Analyses were on the rates of awareness and } \\
\text { possible awareness comparing the BIS and } \\
\text { the ETAG groups. Statistical analysis } \\
\text { included: chi-square test, Fisher's exact test, } \\
\text { an unpaired t-test, and an unpaired Mann- } \\
\text { Whitney test. No confounding variables } \\
\text { mentioned. Intention-to-treat analysis was } \\
\text { planned and aside from the few patients who } \\
\text { were excluded for reasons mentioned above, } \\
\text { all others included in the data analysis. }\end{array}$ \\
\hline
\end{tabular}


Guide to an Overall Critique of a Quantitative Research Report

\begin{tabular}{|c|c|c|}
\hline $\begin{array}{l}\text { Aspect of the } \\
\text { Report }\end{array}$ & Critiquing Questions & Detailed Critiquing Guidelines \\
\hline $\begin{array}{l}\text { Data Analysis } \\
\text { (continued) }\end{array}$ & $\begin{array}{l}\text { - Were problems of missing values evaluated and } \\
\text { adequately addressed? }\end{array}$ & $\begin{array}{l}\text { Missing values (excluded patients) were } \\
\text { described in detail and addressed. The only } \\
\text { aspect that could have been explained in } \\
\text { greater detail were technical difficulties. }\end{array}$ \\
\hline Findings & $\begin{array}{l}\text { - Was information about statistical significance } \\
\text { presented? Was information about effect size and } \\
\text { precision of estimates (confidence intervals) } \\
\text { presented? } \\
\text { - Were the findings adequately summarized, with good } \\
\text { use of tables and figures? } \\
\text { Were findings reported in a manner that facilitates a } \\
\text { meta-analysis, and with sufficient information } \\
\text { needed for EBP? }\end{array}$ & $\begin{array}{l}\text { Information about statistical significance was } \\
\text { included. Although effect size was not } \\
\text { included in the study, comparisons between } \\
\text { the BIS and ETAG groups and confidence } \\
\text { levels were included. Findings were } \\
\text { displayed in tables and figures and included } \\
\text { most of the pertinent information obtained. } \\
\text { Findings were not written in a form that } \\
\text { facilitates or refers to a meta-analysis, } \\
\text { however, it would be difficult to assume that } \\
\text { a single study of } 2000 \text { patients, no matter } \\
\text { how well done, would be sufficient to } \\
\text { become EBP considering how low the overall } \\
\text { incidence rate of IA is. }\end{array}$ \\
\hline $\begin{array}{l}\text { Discussion } \\
\text { Interpretation of the }\end{array}$ & $\begin{array}{l}\text { Were all major findings interpreted and discussed } \\
\text { within the context of prior research and/or the } \\
\text { study's conceptual framework? }\end{array}$ & $\begin{array}{l}\text { Findings were compared with prior research } \\
\text { and discussed. Only potential causal } \\
\text { inference was this was a study of awareness; }\end{array}$ \\
\hline
\end{tabular}




\begin{tabular}{|c|c|c|}
\hline findings & $\begin{array}{l}\text { - Were casual inferences, if any, justified? } \\
\text { - Was the issue of clinical significance discussed? } \\
\text { - Were interpretations well-founded and consistent } \\
\text { with the study's limitations? } \\
\text { - Did the report address the issue of the } \\
\text { generalizability of the findings? }\end{array}$ & $\begin{array}{l}\text { there is some subjectivity involved and } \\
\text { repeating the same questions may create false } \\
\text { memories. However, this is something that } \\
\text { any awareness study will encounter. Clinical } \\
\text { significance was discussed in relation to the } \\
\text { number needed to treat in order to benefit and } \\
\text { harm which were } 179 \text { and } 175 \text {, respectively, } \\
\text { and the results obtained were consistent with } \\
\text { these numbers. Limitations discussed. } \\
\text { Although BIS did not predictably prevent } \\
\text { awareness under these variables, it may still } \\
\text { have value in preventing awareness under a } \\
\text { different type of anesthesia (total intravenous } \\
\text { anesthesia). }\end{array}$ \\
\hline $\begin{array}{l}\text { Implications/ } \\
\text { recommendations }\end{array}$ & $\begin{array}{l}\text { Did the researchers discuss the implications of the } \\
\text { study for clinical practice or further research-and } \\
\text { were those implications reasonable and complete? }\end{array}$ & $\begin{array}{l}\text { No mention of further research on this topic } \\
\text { Implications from results seemed reasonable } \\
\text { and complete under these specific variables } \\
\text { but would not be feasible to implement in } \\
\text { clinical practice based on sample size in this } \\
\text { study. }\end{array}$ \\
\hline $\begin{array}{l}\text { General Issues } \\
\text { Presentation }\end{array}$ & $\begin{array}{l}\text { - Was the report well-written, organized, and } \\
\text { sufficiently detailed for critical analysis? } \\
\text { - In intervention studies, was a CONSORT flowchart } \\
\text { provided to show the flow of participants in the } \\
\text { study? }\end{array}$ & $\begin{array}{l}\text { Report well-written, organized with sufficient } \\
\text { detail. Detail was plentiful in terms of data, } \\
\text { demographics, descriptions of the patients' } \\
\text { accounts of awareness, and BIS/ETAG data. } \\
\text { A CONSORT flowchart was included as a }\end{array}$ \\
\hline
\end{tabular}




\begin{tabular}{|l|l|l|}
\hline & & $\begin{array}{l}\text { figure, which showed the breakdown of study } \\
\text { participants. }\end{array}$ \\
\hline
\end{tabular}

\section{Guide to an Overall Critique of a Quantitative Research Report}

\begin{tabular}{|c|c|c|}
\hline $\begin{array}{l}\text { Aspect of the } \\
\text { Report }\end{array}$ & Critiquing Questions & Detailed Critiquing Guidelines \\
\hline $\begin{array}{l}\text { General Issues } \\
\text { Presentation } \\
\text { (continued) }\end{array}$ & $\begin{array}{l}\text { - Was the report written in a manner that makes the } \\
\text { findings accessible to practicing nurses? }\end{array}$ & $\begin{array}{l}\text { Findings are easily accessible and } \\
\text { interpretable anesthesia practitioners. }\end{array}$ \\
\hline $\begin{array}{l}\text { Researcher } \\
\text { credibility }\end{array}$ & $\begin{array}{l}\text { - Do the researchers' clinical, substantive, or } \\
\text { methodologic qualifications and experience enhance } \\
\text { confidence in the findings and their interpretation? }\end{array}$ & $\begin{array}{l}\text { No mention made of the researchers' } \\
\text { background or experience. }\end{array}$ \\
\hline $\begin{array}{l}\text { Summary } \\
\text { assessment }\end{array}$ & $\begin{array}{l}\text { - Despite any limitations, do the study findings appear } \\
\text { to be valid-do you have confidence in the truth } \\
\text { value of the results? } \\
\text { - Does the study contribute any meaningful evidence } \\
\text { that can be used in nursing practice or that is useful } \\
\text { to the nursing discipline? }\end{array}$ & $\begin{array}{l}\text { Findings definitely appear to be valid and no } \\
\text { reason not to believe the truth-value in the } \\
\text { results. } \\
\text { Study does contribute to the topic of IA and } \\
\text { BIS monitoring. It is useful to anesthesia } \\
\text { practitioners but probably cannot be } \\
\text { considered definitive based on previously } \\
\text { mentioned comments regarding sample size } \\
\text { and was a single-center study. }\end{array}$ \\
\hline
\end{tabular}


*Reprinted with permission from the editor of D. Polit and C. Beck (2017). Nursing Research. Generating and assessing evidence for nursing practice $\left(10^{\text {th }} \mathrm{ed}\right.$.). Wolters Kluwer. 


\section{Guide to an Overall Critique of a Quantitative Research Report}

Table C3

Sebel, P. S., Bowdle, T. A., Ghoneim, M. M., Rampil, I. J., Padilla, R. E., Gan, T. J., \& Domino, K. B. (2004). The incidence of awareness during anesthesia: a multicenter United States study. Anesthesia and Analgesia, 99(3), 833.

\begin{tabular}{|l|l|l|}
\multicolumn{1}{|c|}{$\begin{array}{l}\text { Aspect of the } \\
\text { Report }\end{array}$} & \multicolumn{1}{c|}{ Critiquing Questions } & \multicolumn{1}{c|}{ Detailed Critiquing Guidelines } \\
\hline Title & $\begin{array}{l}\text { Is the title a good one, succinctly suggesting key } \\
\text { variables and the study population? }\end{array}$ & $\begin{array}{l}\text { The title is appropriate but does not indicate } \\
\text { any of the key variables or give any details } \\
\text { about the study population. }\end{array}$ \\
\hline Abstract & $\begin{array}{l}\text { Did the abstract clearly and concisely summarize the } \\
\text { main features of the report (problem, methods, } \\
\text { results, conclusions)? }\end{array}$ & $\begin{array}{l}\text { The abstract included the main features of } \\
\text { the report and addressed the problem, } \\
\text { methods, results, and conclusion. }\end{array}$ \\
\hline $\begin{array}{l}\text { Introduction } \\
\text { Statement of the } \\
\text { problem }\end{array}$ & $\begin{array}{l}\text { Was the problem stated unambiguously, and was it } \\
\text { easy to identify? } \\
\text { Is the problem statement build a persuasive argument } \\
\text { for the new study? } \\
\text { Was there a good match between the research } \\
\text { problem and the methods used -that is, was a } \\
\text { quantitative approach appropriate? }\end{array}$ & $\begin{array}{l}\text { Problem stated clearly and easy to identify. } \\
\text { Problem statement builds a persuasive } \\
\text { argument for this study as they explained all } \\
\text { previous studies were done outside the US } \\
\text { and none were done domestically. There } \\
\text { was a good match between the problem and } \\
\text { methods. A quantitative approach was used } \\
\text { appropriately. }\end{array}$ \\
\hline $\begin{array}{l}\text { Hypotheses or } \\
\text { research questions }\end{array}$ & $\begin{array}{l}\text { Were research questions and/or hypotheses explicitly } \\
\text { stated? If not, was their absence justified? }\end{array}$ & $\begin{array}{l}\text { The research question was clearly stated as } \\
\text { the purpose was to "establish the incidence }\end{array}$ \\
\hline
\end{tabular}




\begin{tabular}{|l|l|l|}
\hline & $\begin{array}{l}\text { Were questions and hypotheses appropriately } \\
\text { worded, with clear specification of key variables and } \\
\text { the study population? } \\
\text { Were the questions/hypotheses consistent with } \\
\text { existing knowledge? }\end{array}$ & $\begin{array}{l}\text { of awareness with recall during routine } \\
\text { general anesthetic practice in the US." One } \\
\text { of the key variables was the use of BIS when } \\
\text { possible. Study population was not worded } \\
\text { in the hypothesis/study question, but was } \\
\text { clearly described in methods section. Key } \\
\text { variables were clearly described in methods } \\
\text { giving details about the interviews and } \\
\text { questions as well as period of time for when } \\
\text { the interview was to take place. Hypothesis } \\
\text { was consistent with existing knowledge. }\end{array}$ \\
\hline Literature review & $\begin{array}{l}\text { Was the literature review up-to-date and based } \\
\text { mainly on primary sources? } \\
\text { Did the review provide a state-of-the-art synthesis of } \\
\text { evidence on the problem? } \\
\text { Did the literature review provide a strong basis for } \\
\text { the new study? }\end{array}$ & $\begin{array}{l}\text { No identified literature review section; } \\
\text { however, authors referenced studies in their } \\
\text { discussion section when comparing results. } \\
\text { Study did not produce a surprise result on } \\
\text { the problem; it confirmed prior estimations } \\
\text { of the rates of awareness of patients } \\
\text { undergoing general anesthesia. }\end{array}$ \\
\hline
\end{tabular}

\section{Guide to an Overall Critique of a Quantitative Research Report}

\section{\begin{tabular}{|l|l} 
Aspect of the Report & Critiquing Questions
\end{tabular}}

Conceptual/theoretical

framework
- Were key concepts adequately defined conceptually?

- Was a conceptual/theoretical framework articulated-and, if so, was it appropriate? If not, is

\section{Detailed Critiquing Guidelines}

Key concepts were adequately explained. No theoretical framework mentioned. It seems 


\begin{tabular}{|c|c|c|}
\hline & $\begin{array}{l}\text { the absence of a framework justified? } \\
\text { - Were the questions/hypotheses consistent with the } \\
\text { framework? }\end{array}$ & $\begin{array}{l}\text { that the lack of framework is somewhat } \\
\text { justifiable since the primary purpose of this } \\
\text { study was to confirm previous reported data. }\end{array}$ \\
\hline $\begin{array}{l}\text { Method } \\
\text { Protection of human } \\
\text { rights }\end{array}$ & $\begin{array}{l}\text { - Were appropriate procedures used to safe-guard the } \\
\text { rights of study participants? } \\
\text { - Was the study externally reviewed by an IRB/ethics } \\
\text { review board? } \\
\text { - Was the study designed to minimize risks and } \\
\text { maximize benefits to participants? }\end{array}$ & $\begin{array}{l}\text { Appropriate safeguards were implemented as } \\
\text { IRBs at each of the academic medical } \\
\text { centers approved this study and patients also } \\
\text { needed to provide informed (verbal or } \\
\text { written) consent. Study was designed to } \\
\text { minimize risks. Anesthesiologists were not } \\
\text { aware of patient participation. It was up to } \\
\text { anesthesia's discretion whether or not to use } \\
\text { BIS and what the overall anesthesia plan } \\
\text { would be. }\end{array}$ \\
\hline Research design & $\begin{array}{l}\text { - Was the most rigorous design used, given the study } \\
\text { - Wurpose? } \\
\text { - Were appropriate comparisons made to enhance } \\
\text { interpretability of the findings? } \\
\text { - Was the number of data collection points } \\
\text { appropriate? } \\
\text { Did the design minimize biases and threats to the } \\
\text { internal, construct, and external validity of the study } \\
\text { (e.g., was blinding used, was attrition minimized)? }\end{array}$ & $\begin{array}{l}\text { It was not the most rigorous design as this } \\
\text { was a nonrandomized study. Number of } \\
\text { data collection points was appropriate as the } \\
\text { study had based it on results from some prior } \\
\text { research. Design did try and minimize } \\
\text { biases. Internally, the attending } \\
\text { anesthesiologist provided anesthesia at their } \\
\text { discretion and not under the pretense of } \\
\text { being involved in a study regarding } \\
\text { awareness. One item that cannot be } \\
\text { corrected for in an awareness study is the } \\
\text { patient possibly increasing their incidence of }\end{array}$ \\
\hline
\end{tabular}




\begin{tabular}{|c|c|c|}
\hline & & $\begin{array}{l}\text { self-reporting of awareness. Authors noted } \\
\text { this would be an issue for all awareness } \\
\text { studies to encounter. Problem with attrition } \\
\text { rate. Originally, they had 20,402 } \\
\text { participants but after some being unable to } \\
\text { be interviewed after surgery along, with } \\
\text { those who did not meet the inclusion criteria, } \\
\text { this number dropped to } 19,575 \text {. Out of these } \\
\text { eligible participants, they interviewed } 85 \% \\
\text { (16,544) in the recovery room and then just } \\
67 \%(13,123) \text { in the follow-up second } \\
\text { interview. Regarding external validity: one } \\
\text { of the seven IRBs required that the initial } \\
\text { interview be conducted after the patient had } \\
\text { left the post anesthesia care unit unlike the } \\
\text { other seven sites. }\end{array}$ \\
\hline $\begin{array}{l}\text { Population and } \\
\text { sample }\end{array}$ & $\begin{array}{l}\text { - Was the population identified? Was the sample } \\
\text { described in sufficient detail? } \\
\text { - Was the best possible sampling design used to } \\
\text { enhance the sample's representativeness? Were } \\
\text { sampling biases minimized? } \\
\text { - Was the sample size based on a power analysis? }\end{array}$ & $\begin{array}{l}\text { Study population well-identified with key } \\
\text { demographics comprising some of the } \\
\text { study's tables. Aside from a lack of detail } \\
\text { regarding the attrition rate, sample was } \\
\text { described in detail. Sampling design was } \\
\text { well done as a wide variety of patients and } \\
\text { types of surgery were among those in the } \\
\text { sample and sampling bias does appear to be } \\
\text { minimized. Study did not refer to a power } \\
\text { analysis being done when projecting an }\end{array}$ \\
\hline
\end{tabular}




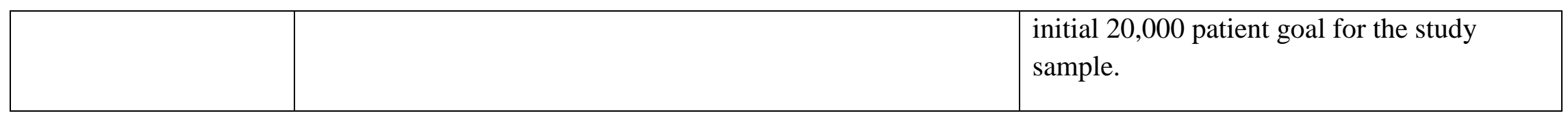

\section{Guide to an Overall Critique of a Quantitative Research Report}

\begin{tabular}{|c|c|c|}
\hline $\begin{array}{l}\text { Aspect of the } \\
\text { Report }\end{array}$ & Critiquing Questions & Detailed Critiquing Guidelines \\
\hline $\begin{array}{l}\text { Data collection and } \\
\text { measurement }\end{array}$ & $\begin{array}{l}\text { - Were the operational and conceptual definitions } \\
\text { congruent? } \\
\text { - Were key variables measured using an appropriate } \\
\text { method (e.g., interviews, observations, and so on)? } \\
\text { Were specific instruments adequately described and } \\
\text { were they good choices, given the study population } \\
\text { and the variables being studied? } \\
\text { - Did the report provide evidence that the data } \\
\text { collection methods yielded data that were reliable, } \\
\text { valid and responsive? }\end{array}$ & $\begin{array}{l}\text { Operational and conceptual definitions are } \\
\text { not congruent. Operational definition is in } \\
\text { the form of interview given to patients after } \\
\text { their surgery while the conceptual definition } \\
\text { is what was being measured, awareness. } \\
\text { Appropriate methods were used to measure } \\
\text { awareness as an interview in the recovery } \\
\text { room and follow-up interview days to weeks } \\
\text { later were conducted in most cases. The first } \\
\text { interview well described in Tables } 1 \text { and } 2 \\
\text { but there was not a good description of } \\
\text { follow-up interview and if it differed at all } \\
\text { from the first interview format. Included } \\
\text { details about the cases of awareness with } \\
\text { good details about the actual descriptions of } \\
\text { what the patients remembered. }\end{array}$ \\
\hline Procedures & $\begin{array}{l}\text { If there was an intervention, was it adequately } \\
\text { described, and was it rigorously developed and }\end{array}$ & Use of BIS as intervention but not used at all \\
\hline
\end{tabular}




\begin{tabular}{|c|c|c|}
\hline & $\begin{array}{l}\text { implemented? Did most participants allocated to the } \\
\text { intervention group actually receive it? Was there } \\
\text { evidence of intervention fidelity? } \\
\text { - Were data collected in a manner that minimized bias? } \\
\text { Were the staff who collected data appropriately } \\
\text { trained? }\end{array}$ & $\begin{array}{l}\text { sites as some sites did not have it as an } \\
\text { option and the study left its use to the } \\
\text { discretion of the anesthesia provider. BIS } \\
\text { adequately described. As BIS was not the } \\
\text { primary outcome measured in the study, it } \\
\text { was used by 38\% of all cases in the study. } \\
\text { Intraoperative awareness was the primary } \\
\text { outcome, there was evidence of intervention } \\
\text { fidelity since } 85 \% \text { and } 67 \% \text { of the evaluable } \\
\text { patients were interviewed in the recovery } \\
\text { room and as a follow-up, respectively. } \\
\text { Seems data was collected in a way that } \\
\text { minimized bias. Anesthesiologist not aware } \\
\text { of patient participation in the study and thus } \\
\text { would have no bias. The use of the BIS was } \\
\text { also at their discretion. Each patient was } \\
\text { interviewed with the same structured } \\
\text { interview. One critical aspect where bias } \\
\text { was definitely a factor was data revealed } \\
\text { approximately half of the awareness cases } \\
\text { were detected in the second interview. Since } \\
\text { the interview rate dropped from } 85 \% \text { to } 67 \% \\
\text { between interviews, data was biased in the } \\
\text { direction of underestimating the incidence of } \\
\text { awareness. No mention of the level of } \\
\text { training of the staff who collected data. }\end{array}$ \\
\hline
\end{tabular}




\begin{tabular}{|c|c|c|}
\hline Data Analysis & $\begin{array}{l}\text { - Were analyses undertaken to address each research } \\
\text { - Wuestion or test each hypothesis? } \\
\text { level of measurement of the variables, number of } \\
\text { groups being compared, and assumptions of the } \\
\text { texts? } \\
\text { - Was a powerful analytic method used? (e.g., did the } \\
\text { analysis help to control for confounding variables)? } \\
\text { - Were type I and Type II errors avoided or } \\
\text { minimized? } \\
\text { In intervention studies, was an intention-to-treat } \\
\text { analysis performed? }\end{array}$ & $\begin{array}{l}\text { Analyses done to address the incidence of } \\
\text { awareness. Included Fisher's exact, } \chi^{2} \text { tests } \\
\text { with Yate's correction, logistic regression, } \\
\text { and odds ratios. Appropriate statistical } \\
\text { methods given the data collected. As } \\
\text { mentioned earlier, the methods did try to } \\
\text { control confounding variables by not } \\
\text { informing the anesthesiologists regarding } \\
\text { patient participation. Type I and II errors } \\
\text { were minimized. As all of the patients who } \\
\text { were interviewed were included in the } \\
\text { analysis, it can be considered that an } \\
\text { intention-to-treat analysis was performed. }\end{array}$ \\
\hline
\end{tabular}

\section{Guide to an Overall Critique of a Quantitative Research Report}

\begin{tabular}{|l|c|l|}
\hline \multicolumn{1}{|c|}{$\begin{array}{c}\text { Aspect of the } \\
\text { Report }\end{array}$} & \multicolumn{1}{|c|}{ Critiquing Questions } & \multicolumn{1}{c|}{ Detailed Critiquing Guidelines } \\
\hline $\begin{array}{l}\text { Data Analysis } \\
\text { (continued) }\end{array}$ & $\begin{array}{l}\text { Were problems of missing values evaluated and } \\
\text { adequately addressed? }\end{array}$ & $\begin{array}{l}\text { Although 20,402 patients were enrolled in the } \\
\text { study, 827 excluded because could not be } \\
\text { interviewed after surgery (no explanation } \\
\text { given regarding possible reasons). Only } \\
16,544 \text { out of 19,575 patients were } \\
\text { interviewed in the recovery room and no }\end{array}$ \\
\hline
\end{tabular}




\begin{tabular}{|c|c|c|}
\hline & & details given why 15\% were not interviewed. \\
\hline Findings & $\begin{array}{l}\text { Was information about statistical significance } \\
\text { presented? Was information about effect size and } \\
\text { precision of estimates (confidence intervals) } \\
\text { presented? } \\
\text { - Were the findings adequately summarized, with good } \\
\text { use of tables and figures? } \\
\text { Were findings reported in a manner that facilitates a } \\
\text { meta-analysis, and with sufficient information } \\
\text { needed for EBP? }\end{array}$ & $\begin{array}{l}\text { Although statistical analysis was performed, } \\
\text { no statistical significance found. Study } \\
\text { concluded no significant association between } \\
\text { the use of BIS monitoring and incidence of } \\
\text { awareness. Confidence intervals reported. } \\
\text { Study summarized findings adequately in } \\
\text { tables and figures. Study concluded results } \\
\text { mirrored prior studies' findings on the rate of } \\
\text { IA; however, this study mentioned potential } \\
\text { biases in their data which would reflect in } \\
\text { more data and studies being needed before an } \\
\text { EBP can be established. }\end{array}$ \\
\hline $\begin{array}{l}\text { Discussion } \\
\text { Interpretation of the } \\
\text { findings }\end{array}$ & $\begin{array}{l}\text { - Were all major findings interpreted and discussed } \\
\text { within the context of prior research and/or the } \\
\text { study’s conceptual framework? } \\
\text { - Were casual inferences, if any, justified? } \\
\text { - Was the issue of clinical significance discussed? } \\
\text { - Were interpretations well-founded and consistent } \\
\text { with the study’s limitations? } \\
\text { Did the report address the issue of the } \\
\text { generalizability of the findings? }\end{array}$ & $\begin{array}{l}\text { Major findings of the study were discussed } \\
\text { along with prior research. Authors compared } \\
\text { results and attempted to explain some of their } \\
\text { findings with prior research. Some } \\
\text { discussion of causal inferences. Authors } \\
\text { discussed the possible cases of awareness } \\
\text { were approximately double of previous } \\
\text { research. Mentioned if patients know that } \\
\text { they are in an awareness study, they may be } \\
\text { more prone to believe they did have } \\
\text { awareness. Clinical significance was not } \\
\text { mentioned although this may be as their }\end{array}$ \\
\hline
\end{tabular}




\begin{tabular}{|c|c|c|}
\hline & & $\begin{array}{l}\text { results mirrored previous results and their } \\
\text { findings on BIS monitoring were uneventful. } \\
\text { Study's interpretations did seem to be } \\
\text { consistent with the limitations, as they } \\
\text { believe they may have underestimated rates } \\
\text { of awareness due to their significantly lower } \\
\text { follow-up interview rate when also combined } \\
\text { with the fact that more than half of the cases } \\
\text { of awareness were found after this } 2^{\text {nd }} \\
\text { interview. Study had no discussion regarding } \\
\text { generalizability and based on the data in } \\
\text { tables, it would be hard to determine the } \\
\text { applicability without more information (such } \\
\text { as surgery type). }\end{array}$ \\
\hline $\begin{array}{l}\text { Implications/ } \\
\text { recommendations }\end{array}$ & $\begin{array}{l}\text { Did the researchers discuss the implications of the } \\
\text { study for clinical practice or further research-and } \\
\text { were those implications reasonable and complete? }\end{array}$ & $\begin{array}{l}\text { Authors discussed use of BIS monitoring and } \\
\text { potential to reduce awareness. Explained } \\
\text { although their data did not confirm this } \\
\text { applicability, more research needed since this } \\
\text { was not a primary outcome of their research } \\
\text { and no randomization occurred for those who } \\
\text { did and did not receive BIS monitoring along } \\
\text { with a lack of BIS guidelines for anesthesia } \\
\text { providers to use. They referenced other data, } \\
\text { which supported the use of BIS to reduce IA. }\end{array}$ \\
\hline General Issues & $\begin{array}{l}\text { - Was the report well-written, organized, and } \\
\text { sufficiently detailed for critical analysis? }\end{array}$ & The report seemed well-written and \\
\hline
\end{tabular}




\begin{tabular}{|l|l|l|}
\hline Presentation & $\begin{array}{l}\text { In intervention studies, was a CONSORT flowchart } \\
\text { provided to show the flow of participants in the } \\
\text { study? }\end{array}$ & $\begin{array}{l}\text { organized with sufficient detail for critical } \\
\text { analysis. Although it was lacking in some } \\
\text { areas, as a whole it was adequately done. } \\
\text { There was no CONSORT flowchart. }\end{array}$ \\
\hline
\end{tabular}

Guide to an Overall Critique of a Quantitative Research Report

\begin{tabular}{|c|c|c|}
\hline $\begin{array}{l}\text { Aspect of the } \\
\text { Report }\end{array}$ & Critiquing Questions & Detailed Critiquing Guidelines \\
\hline $\begin{array}{l}\text { General Issues } \\
\text { Presentation } \\
\text { (continued) }\end{array}$ & $\begin{array}{l}\text { - Was the report written in a manner that makes the } \\
\text { findings accessible to practicing nurses? }\end{array}$ & $\begin{array}{l}\text { Report was written to enable nurses to utilize } \\
\text { findings; however, there was no difference in } \\
\text { their findings from other historical data. }\end{array}$ \\
\hline $\begin{array}{l}\text { Researcher } \\
\text { credibility }\end{array}$ & $\begin{array}{l}\text { Do the researchers' clinical, substantive, or } \\
\text { methodologic qualifications and experience enhance } \\
\text { confidence in the findings and their interpretation? }\end{array}$ & $\begin{array}{l}\text { No details given regarding the researchers' } \\
\text { clinical qualifications beyond degrees earned. } \\
\text { Mentioned the manufacturer of BIS provided } \\
\text { statistical processing support. The overall } \\
\text { methodology utilized appears to be sound } \\
\text { albeit somewhat lacking and would have been } \\
\text { better served if more detail given regarding } \\
\text { patient attrition. }\end{array}$ \\
\hline $\begin{array}{l}\text { Summary } \\
\text { assessment }\end{array}$ & $\begin{array}{l}\text { - Despite any limitations, do the study findings appear } \\
\text { to be valid-do you have confidence in the truth } \\
\text { value of the results? } \\
\text { - Does the study contribute any meaningful evidence }\end{array}$ & $\begin{array}{l}\text { Study does appear to be valid especially } \\
\text { when reviewing Table } 4 \text {, which gave detailed } \\
\text { descriptions of the } 25 \text { accounts of awareness. } \\
\text { This was a strong detail and provides }\end{array}$ \\
\hline
\end{tabular}




\begin{tabular}{|l|l|l|}
\hline & $\begin{array}{l}\text { that can be used in nursing practice or that is useful } \\
\text { to the nursing discipline? }\end{array}$ & $\begin{array}{l}\text { convincing data for the reports of awareness. } \\
\text { Study did provide some data in terms of } \\
\text { possible risk factors for awareness (Table 7), } \\
\text { which could potentially be useful for } \\
\text { anesthesia providers in the future with how } \\
\text { they approach their anesthesia plan for } \\
\text { patients who have some of these risk factors. }\end{array}$ \\
\hline
\end{tabular}

*Reprinted with permission from the editor of D. Polit and C. Beck (2017). Nursing Research. Generating and assessing evidence for nursing practice $\left(10^{\text {th }} \mathrm{ed}\right.$.). Wolters Kluwer. 


\section{Guide to an Overall Critique of a Quantitative Research Report}

Table C4

Myles, P., Leslie, K., McNeil, J., Forbes, A., \& Chan, M. (2004). Bispectral index monitoring to prevent awareness during anaesthesia: the B-Aware randomized controlled trial. Lancet, 363 North American Edition (9423), 1757-1763.

\begin{tabular}{|l|l|l|}
\hline \multicolumn{1}{|c|}{$\begin{array}{l}\text { Aspect of the } \\
\text { Report }\end{array}$} & \multicolumn{1}{c|}{ Critiquing Questions } & \multicolumn{1}{c|}{ Detailed Critiquing Guidelines } \\
\hline Title & $\begin{array}{l}\text { Is the title a good one, succinctly suggesting key } \\
\text { variables and the study population? }\end{array}$ & $\begin{array}{l}\text { Title is appropriate except for not identifying } \\
\text { the study population. }\end{array}$ \\
\hline Abstract & $\bullet \begin{array}{l}\text { Did the abstract clearly and concisely summarize the } \\
\text { main features of the report (problem, methods, } \\
\text { results, conclusions)? }\end{array}$ & $\begin{array}{l}\text { Yes, the abstract included a succinct } \\
\text { description of the main sections of the } \\
\text { report. }\end{array}$ \\
\hline $\begin{array}{l}\text { Introduction } \\
\text { Statement of the } \\
\text { problem }\end{array}$ & $\begin{array}{l}\text { Was the problem stated unambiguously, and was it } \\
\text { easy to identify? } \\
\text { Is the problem statement build a persuasive argument } \\
\text { for the new study? } \\
\text { Was there a good match between the research } \\
\text { problem and the methods used -that is, was a } \\
\text { quantitative approach appropriate? }\end{array}$ & $\begin{array}{l}\text { Awareness was defined and occurrence rates } \\
\text { were described. Problem statement } \\
\text { identifies the problem, suggests past } \\
\text { approaches to address it, and offers a } \\
\text { quantitative approach to match the proposed } \\
\text { study with the problem. }\end{array}$ \\
\hline $\begin{array}{l}\text { Hypotheses or } \\
\text { research questions }\end{array}$ & $\begin{array}{l}\text { Were research questions and/or hypotheses explicitly } \\
\text { stated? If not, was their absence justified? } \\
\text { Were questions and hypotheses appropriately } \\
\text { worded, with clear specification of key variables and } \\
\text { the study population? } \\
\text { Were the questions/hypotheses consistent with }\end{array}$ & $\begin{array}{l}\text { Hypothesis clearly stated, included variables } \\
\text { and identified study population. At the time, } \\
\text { existing knowledge was limited regarding } \\
\text { awareness monitoring, so it appears that they } \\
\text { were consistent. }\end{array}$ \\
\hline
\end{tabular}




\begin{tabular}{|l|l|l|}
\hline Literature review & existing knowledge? & No literature review section. \\
& $\begin{array}{l}\text { Was the literature review up-to-date and based } \\
\text { mainly on primary sources? }\end{array}$ & $\begin{array}{l}\text { Did the review provide a state-of-the-art synthesis of } \\
\text { evidence on the problem? }\end{array}$ \\
$\begin{array}{l}\text { Did the literature review provide a strong basis for } \\
\text { the new study? }\end{array}$ & \\
\hline
\end{tabular}

\section{Guide to an Overall Critique of a Quantitative Research Report}

\section{Aspect of the Report}

Conceptual/theoretical

framework

Method

Protection of human rights

\section{Critiquing Questions}

- Were key concepts adequately defined conceptually?

- Was a conceptual/theoretical framework articulated-and, if so, was it appropriate? If not, is the absence of a framework justified?

- Were the questions/hypotheses consistent with the framework?

- Were appropriate procedures used to safe-guard the rights of study participants?

- Was the study externally reviewed by an IRB/ethics review board?

- Was the study designed to minimize risks and maximize benefits to participants?
Detailed Critiquing Guidelines

Although a theoretical framework was not articulated, key concepts regarding the study were adequately discussed.

Study was approved by the ethics committee of each participating center. Elective patients gave written consent while emergency conscious patients were given a brief verbal description. As not all facilities even use BIS, it would appear that the riskbenefit difference was insignificant as it was the only variable in the provided care. An independent group did an interim analysis after slightly more than $50 \%$ of enrolled 


\begin{tabular}{|c|c|c|}
\hline & & $\begin{array}{l}\text { patients to see if there was any evidence of } \\
\text { harm, which there was not. }\end{array}$ \\
\hline Research design & $\begin{array}{l}\text { - Was the most rigorous design used, given the study } \\
\text { purpose? } \\
\text { - Were appropriate comparisons made to enhance } \\
\text { interpretability of the findings? } \\
\text { - Was the number of data collection points } \\
\text { appropriate? } \\
\text { int the design minimize biases and threats to the } \\
\text { (e.g., was blinding used, was attrition minimized)? }\end{array}$ & $\begin{array}{l}\text { Rigorous design as it was a multicenter, } \\
\text { double-blind, randomized study. } \\
\text { Appropriate comparisons were made as can } \\
\text { be seen in Table } 1 \text {. BIS and control groups } \\
\text { were similar in their breakdown numbers of } \\
\text { all relevant characteristics. These help to } \\
\text { minimize the threats to internal and external } \\
\text { validity. There is potential for construct } \\
\text { validity issues due to the independent } \\
\text { endpoint adjudication committee composed } \\
\text { of three experienced anesthetists, but the } \\
\text { study took steps to reduce it, namely by their } \\
\text { requirements for awareness and possible } \\
\text { awareness. }\end{array}$ \\
\hline $\begin{array}{l}\text { Population and } \\
\text { sample }\end{array}$ & $\begin{array}{l}\text { - Was the population identified? Was the sample } \\
\text { described in sufficient detail? } \\
\text { - Was the best possible sampling design used to } \\
\text { enhance the sample's representativeness? Were } \\
\text { sampling biases minimized? } \\
\text { - Was the sample size based on a power analysis? }\end{array}$ & $\begin{array}{l}\text { Sample population described in great detail } \\
\text { and required characteristic(s), inclusion, and } \\
\text { exclusion criteria. Sampling biases were } \\
\text { minimized due to exclusion criteria. A } \\
\text { power analysis was conducted while still } \\
\text { allowing for patients dropping out, missing } \\
\text { data, or other human error. }\end{array}$ \\
\hline
\end{tabular}


Guide to an Overall Critique of a Quantitative Research Report

\begin{tabular}{|c|c|c|}
\hline $\begin{array}{l}\text { Aspect of the } \\
\text { Report }\end{array}$ & Critiquing Questions & Detailed Critiquing Guidelines \\
\hline $\begin{array}{l}\text { Data collection and } \\
\text { measurement }\end{array}$ & $\begin{array}{l}\text { - Were the operational and conceptual definitions } \\
\text { congruent? } \\
\text { - Were key variables measured using an appropriate } \\
\text { method (e.g., interviews, observations, and so on)? } \\
\text { - Were specific instruments adequately described and } \\
\text { were they good choices, given the study population } \\
\text { and the variables being studied? } \\
\text { Did the report provide evidence that the data } \\
\text { collection methods yielded data that were reliable, } \\
\text { valid and responsive? }\end{array}$ & $\begin{array}{l}\text { Key variable being measured was IA and } \\
\text { was measured by the interview format which } \\
\text { was appropriate. The structured } \\
\text { questionnaire used to identify awareness was } \\
\text { not described in any detail. Some additional } \\
\text { analysis was provided in order to examine } \\
\text { how certain factors (age, sex, cardiac } \\
\text { surgery) might alter some of the data. }\end{array}$ \\
\hline Procedures & $\begin{array}{l}\text { - If there was an intervention, was it adequately } \\
\text { described, and was it rigorously developed and } \\
\text { implemented? Did most participants allocated to the } \\
\text { intervention group actually receive it? Was there } \\
\text { evidence of intervention fidelity? } \\
\text { - Were data collected in a manner that minimized bias? } \\
\text { Were the staff who collected data appropriately } \\
\text { trained? }\end{array}$ & $\begin{array}{l}\text { Use of BIS monitoring was the intervention } \\
\text { and it was adequately described. Out of the } \\
1,225 \text { patients allocated to the BIS group, } \\
\text { only } 14 \text { did not end up utilizing it. It } \\
\text { appeared data was collected in a way that } \\
\text { minimized bias; however, staff's training } \\
\text { was not described in any detail to get a true } \\
\text { understanding on how qualified they were. } \\
\text { It would have been beneficial to describe } \\
\text { how "experienced” the investigating } \\
\text { committee who followed-up with the } \\
\text { patients actually were. }\end{array}$ \\
\hline
\end{tabular}




\begin{tabular}{|l|l|l|}
\hline Data Analysis & $\begin{array}{l}\text { Were analyses undertaken to address each research } \\
\text { question or test each hypothesis? }\end{array}$ & $\begin{array}{l}\text { Adequate statistical analysis was performed. } \\
\text { All data on primary, secondary, and safety } \\
\text { analyses were used. The primary outcome }\end{array}$ \\
& $\begin{array}{l}\text { Were appropriate statistical methods used, given the } \\
\text { level of measurement of the variables, number of } \\
\text { groups being compared, and assumptions of the } \\
\text { texts? }\end{array}$ & $\begin{array}{l}\text { of awareness was measured with Fisher's } \\
\text { exact test. An intention-to-treat analysis was } \\
\text { completed. }\end{array}$ \\
& $\begin{array}{l}\text { Was a powerful analytic method used? (e.g., did the } \\
\text { analysis help to control for confounding variables)? }\end{array}$ & \\
Were type I and Type II errors avoided or \\
minimized? \\
In intervention studies, was an intention-to-treat \\
analysis performed?
\end{tabular}

\section{Guide to an Overall Critique of a Quantitative Research Report}

\begin{tabular}{|c|c|c|}
\hline $\begin{array}{l}\text { Aspect of the } \\
\text { Report }\end{array}$ & Critiquing Questions & Detailed Critiquing Guidelines \\
\hline $\begin{array}{l}\text { Data Analysis } \\
\text { (continued) }\end{array}$ & $\begin{array}{l}\text { - Were problems of missing values evaluated and } \\
\text { adequately addressed? }\end{array}$ & $\begin{array}{l}\text { All missing or erroneous data was described } \\
\text { but some of it was used in the analysis. }\end{array}$ \\
\hline Findings & $\begin{array}{l}\text { Was information about statistical significance } \\
\text { presented? Was information about effect size and } \\
\text { precision of estimates (confidence intervals) } \\
\text { presented? } \\
\text { - Were the findings adequately summarized, with good } \\
\text { use of tables and figures? } \\
\text { - Were findings reported in a manner that facilitates a }\end{array}$ & $\begin{array}{l}\text { Statistical significance and confidence } \\
\text { intervals were reported in the results section. } \\
\text { Tables were well done including all of the } \\
\text { pertinent data and patient population } \\
\text { characteristics for side-by-side comparison. }\end{array}$ \\
\hline
\end{tabular}




\begin{tabular}{|c|c|c|}
\hline & $\begin{array}{l}\text { meta-analysis, and with sufficient information } \\
\text { needed for EBP? }\end{array}$ & \\
\hline $\begin{array}{l}\text { Discussion } \\
\text { Interpretation of the } \\
\text { findings }\end{array}$ & $\begin{array}{l}\text { - Were all major findings interpreted and discussed } \\
\text { within the context of prior research and/or the } \\
\text { study’s conceptual framework? } \\
\text { - Were casual inferences, if any, justified? } \\
\text { - Was the issue of clinical significance discussed? } \\
\text { - Were interpretations well-founded and consistent } \\
\text { with the study's limitations? } \\
\text { Did the report address the issue of the } \\
\text { generalizability of the findings? }\end{array}$ & $\begin{array}{l}\text { Authors discussed results and expected } \\
\text { findings based on previous studies. Authors } \\
\text { discussed two of the cases of awareness in the } \\
\text { BIS guided group in order to explain the data } \\
\text { and somewhat justify these occurrences. The } \\
\text { study addressed the generalizability of } \\
\text { findings and stated they were applicable as } \\
\text { the results were obtained in a real-life } \\
\text { scenario. Authors mentioned population was } \\
\text { comprised of patients that would be } \\
\text { considered to be more high-risk for } \\
\text { awareness. }\end{array}$ \\
\hline $\begin{array}{l}\text { Implications/ } \\
\text { recommendations }\end{array}$ & $\begin{array}{l}\text { Did the researchers discuss the implications of the } \\
\text { study for clinical practice or further research-and } \\
\text { were those implications reasonable and complete? }\end{array}$ & $\begin{array}{l}\text { Implications were briefly discussed. Study } \\
\text { concluded: BIS monitoring would be } \\
\text { warranted for patients at higher risk for } \\
\text { awareness undergoing general anesthesia. It } \\
\text { is difficult to consider these implications } \\
\text { without more data and research with similar } \\
\text { findings. }\end{array}$ \\
\hline $\begin{array}{l}\text { General Issues } \\
\text { Presentation }\end{array}$ & $\begin{array}{l}\text { Was the report well-written, organized, and } \\
\text { sufficiently detailed for critical analysis? } \\
\text { - In intervention studies, was a CONSORT flowchart } \\
\text { provided to show the flow of participants in the } \\
\text { study? }\end{array}$ & $\begin{array}{l}\text { Report detailed with plenty of analysis and } \\
\text { data that allowed the authors to arrive at } \\
\text { conclusions. Flowchart was included } \\
\text { indicating how participants went from } \\
\text { original participation to those who were }\end{array}$ \\
\hline
\end{tabular}




\begin{tabular}{|l|l|l|}
\hline & & $\begin{array}{l}\text { included in the final results and reasons why } \\
\text { participants were omitted. }\end{array}$ \\
\hline
\end{tabular}

\section{Guide to an Overall Critique of a Quantitative Research Report}

\begin{tabular}{|c|c|c|}
\hline $\begin{array}{l}\text { Aspect of the } \\
\text { Report }\end{array}$ & Critiquing Questions & Detailed Critiquing Guidelines \\
\hline $\begin{array}{l}\text { General Issues } \\
\text { Presentation } \\
\text { (continued) }\end{array}$ & $\begin{array}{l}\text { - Was the report written in a manner that makes the } \\
\text { findings accessible to practicing nurses? }\end{array}$ & $\begin{array}{l}\text { Study allows for easy interpretation for } \\
\text { anesthesia practitioners to incorporate } \\
\text { findings into their practice. }\end{array}$ \\
\hline $\begin{array}{l}\text { Researcher } \\
\text { credibility }\end{array}$ & $\begin{array}{l}\text { Do the researchers' clinical, substantive, or } \\
\text { methodologic qualifications and experience enhance } \\
\text { confidence in the findings and their interpretation? }\end{array}$ & $\begin{array}{l}\text { Some conflict of interest as the company that } \\
\text { manufactures the BIS did provide loan } \\
\text { equipment and some funding for the trial; } \\
\text { provided support for one of the authors for } \\
\text { travel and conference expenses. }\end{array}$ \\
\hline $\begin{array}{l}\text { Summary } \\
\text { assessment }\end{array}$ & $\begin{array}{l}\text { Despite any limitations, do the study findings appear } \\
\text { to be valid-do you have confidence in the truth } \\
\text { value of the results? } \\
\text { - Does the study contribute any meaningful evidence } \\
\text { that can be used in nursing practice or that is useful } \\
\text { to the nursing discipline? }\end{array}$ & $\begin{array}{l}\text { As this was the first large-scale trial done on } \\
\text { BIS monitoring and awareness, results have } \\
\text { some validity. Due to the low numbers } \\
\text { associated with awareness, it would be } \\
\text { beneficial to see if other studies could } \\
\text { validate the results; however, for patients } \\
\text { who are at high risk for awareness, having an } \\
\text { additional monitoring tool to help gauge }\end{array}$ \\
\hline
\end{tabular}




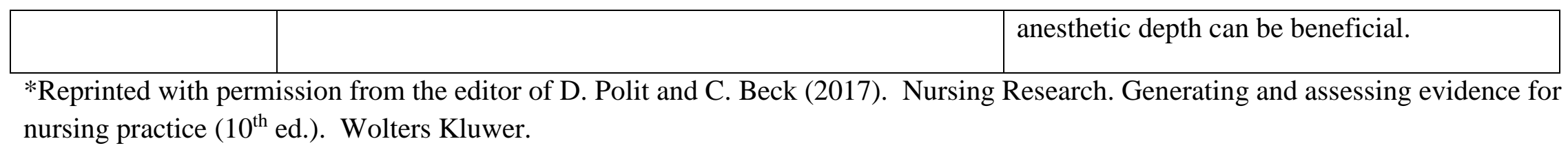
nursing practice $\left(10^{\text {th }}\right.$ ed.). Wolters Kluwer. 


\section{Guide to an Overall Critique of a Quantitative Research Report}

Table C5

Mashour, G., Shanks, A., Tremper, K., Kheterpal, S., Turner, C., Ramachandran, S.,... Avidan, M. (2012). Prevention of intraoperative awareness with explicit recall in an unselected surgical population: a randomized comparative effectiveness trial. Anesthesiology, 117(4), 717-725.

\begin{tabular}{|c|c|c|}
\hline $\begin{array}{l}\text { Aspect of the } \\
\text { Report }\end{array}$ & Critiquing Questions & Detailed Critiquing Guidelines \\
\hline Title & $\begin{array}{l}\text { - Is the title a good one, succinctly suggesting key } \\
\text { variables and the study population? }\end{array}$ & $\begin{array}{l}\text { Title is good and gives details regarding } \\
\text { variables as well as a description of the study } \\
\text { population. The one aspect that is missing is } \\
\text { that a key variable (BIS) is not mentioned in } \\
\text { the title although the outcome variable is. }\end{array}$ \\
\hline Abstract & $\begin{array}{l}\text { Did the abstract clearly and concisely summarize the } \\
\text { main features of the report (problem, methods, } \\
\text { results, conclusions)? }\end{array}$ & $\begin{array}{l}\text { Abstract addressed main features of the } \\
\text { report and had sections about the problem, } \\
\text { methods, results, and conclusions with } \\
\text { succinct summaries for each one. }\end{array}$ \\
\hline $\begin{array}{l}\text { Introduction } \\
\text { Statement of the } \\
\text { problem }\end{array}$ & $\begin{array}{l}\text { - Was the problem stated unambiguously, and was it } \\
\text { easy to identify? } \\
\text { - Is the problem statement build a persuasive argument } \\
\text { for the new study? } \\
\text { - Was there a good match between the research } \\
\text { problem and the methods used -that is, was a } \\
\text { quantitative approach appropriate? }\end{array}$ & $\begin{array}{l}\text { Problem was clearly stated in the first } \\
\text { section of the body. Authors state that IA } \\
\text { can be potentially devastating enough to the } \\
\text { point of leading to PTSD. Problem } \\
\text { statement does build a strong case for this } \\
\text { study. Mentioned previous studies have } \\
\text { focused on high-risk patient populations for }\end{array}$ \\
\hline
\end{tabular}




\begin{tabular}{|c|c|c|}
\hline & & $\begin{array}{l}\text { IA and therefore these authors wanted to } \\
\text { focus on a generalized patient population. } \\
\text { Mentioned a previous study had targeted this } \\
\text { type of patient population but it had several } \\
\text { limitations that limited efficacy. Methods } \\
\text { utilized in this were appropriate given its } \\
\text { problem statement. Quantitative methods } \\
\text { utilized, which is appropriate for a study } \\
\text { targeting rates of IA. }\end{array}$ \\
\hline $\begin{array}{l}\text { Hypotheses or } \\
\text { research questions }\end{array}$ & $\begin{array}{l}\text { - Were research questions and/or hypotheses explicitly } \\
\text { stated? If not, was their absence justified? } \\
\text { - Were questions and hypotheses appropriately } \\
\text { worded, with clear specification of key variables and } \\
\text { the study population? } \\
\text { - Were the questions/hypotheses consistent with } \\
\text { existing knowledge? }\end{array}$ & $\begin{array}{l}\text { Research questions were not specifically } \\
\text { stated, rather a description was made of the } \\
\text { topic along with details regarding the } \\
\text { parameters of the study. Authors did declare } \\
\text { the primary outcome being studied was IA. } \\
\text { Due to what is being studied, it was not } \\
\text { imperative that the research question be } \\
\text { stated. Key variables and study population } \\
\text { were described with sufficient detail. } \\
\text { Authors described past studies that had } \\
\text { influenced their rationale for coming up with } \\
\text { the variables in their study. }\end{array}$ \\
\hline Literature review & $\begin{array}{l}\text { - Was the literature review up-to-date and based } \\
\text { mainly on primary sources? } \\
\text { - Did the review provide a state-of-the-art synthesis of } \\
\text { evidence on the problem? } \\
\text { - Did the literature review provide a strong basis for }\end{array}$ & $\begin{array}{l}\text { Although a true literature review was not } \\
\text { described, the studies reviewed and } \\
\text { described in the introduction were primary } \\
\text { sources and up-to-date. Study described the }\end{array}$ \\
\hline
\end{tabular}




\begin{tabular}{|l|l|l|}
\hline the new study? & $\begin{array}{l}\text { results from previous research but not with } \\
\text { any significant insight; however, the authors } \\
\text { did detail how prior studies caused them to } \\
\text { initiate their research and additional } \\
\text { definitive research is needed in this area. }\end{array}$ \\
\hline
\end{tabular}

\section{Guide to an Overall Critique of a Quantitative Research Report}

\begin{tabular}{|c|c|c|}
\hline Aspect of the Report & Critiquing Questions & Detailed Critiquing Guidelines \\
\hline $\begin{array}{l}\text { Conceptual/theoretical } \\
\text { framework }\end{array}$ & $\begin{array}{l}\text { - Were key concepts adequately defined conceptually? } \\
\text { - Was a conceptual/theoretical framework } \\
\text { articulated-and, if so, was it appropriate? If not, is } \\
\text { the absence of a framework justified? } \\
\text { - Were the questions/hypotheses consistent with the } \\
\text { framework? }\end{array}$ & $\begin{array}{l}\text { Theoretical framework not mentioned but is } \\
\text { not necessarily imperative for this type of } \\
\text { research. Key concepts were succinctly } \\
\text { defined and some details included in tables. }\end{array}$ \\
\hline $\begin{array}{l}\text { Method } \\
\text { Protection of human } \\
\text { rights }\end{array}$ & $\begin{array}{l}\text { - Were appropriate procedures used to safe-guard the } \\
\text { rights of study participants? } \\
\text { - Was the study externally reviewed by an IRB/ethics } \\
\text { review board? } \\
\text { - Was the study designed to minimize risks and } \\
\text { maximize benefits to participants? }\end{array}$ & $\begin{array}{l}\text { Study was reviewed by the University of } \\
\text { Michigan's IRB and deemed to be of } \\
\text { minimal risk to participants. Participants } \\
\text { consented and informed of the risks and } \\
\text { benefits. Similarly to other studies that } \\
\text { compared BIS monitoring to ETAC, there is } \\
\text { minimal if any additional risk if patients are } \\
\text { in the ETAC group. The important aspect is } \\
\text { that anesthesia providers were not given any } \\
\text { protocol on how their choice of anesthesia }\end{array}$ \\
\hline
\end{tabular}




\begin{tabular}{|c|c|c|}
\hline & & should be derived or guided. \\
\hline Research design & $\begin{array}{l}\text { - Was the most rigorous design used, given the study } \\
\text { purpose? } \\
\text { - Were appropriate comparisons made to enhance } \\
\text { interpretability of the findings? } \\
\text { - Was the number of data collection points } \\
\text { appropriate? } \\
\text { Did the design minimize biases and threats to the } \\
\text { internal, construct, and external validity of the study } \\
\text { (e.g., was blinding used, was attrition minimized)? }\end{array}$ & $\begin{array}{l}\text { The study design is rigorous as it is a } \\
\text { comparative effectiveness study and is also a } \\
\text { randomized control trial. Findings were } \\
\text { easily interpretable and an additional post } \\
\text { hoc analysis was done because of a technical } \\
\text { error encountered during the study. Findings } \\
\text { were contrasted and compared with previous } \\
\text { research done. The number of data } \\
\text { collections points were appropriate as } \\
\text { determined by their analyses. Internal } \\
\text { validity was high for this study as all } \\
\text { participants (aside from the anesthesia } \\
\text { providers) were blinded to group assignment } \\
\text { and there was randomization. Construct } \\
\text { validity is high as the modified Brice } \\
\text { questionnaire has been used previously in } \\
\text { research involving IA and is entirely } \\
\text { appropriate for this topic. Attrition was } \\
\text { adequate for the study as 87.0\% of the } \\
\text { ETAC group completed the interview and } \\
87.3 \% \text { of the BIS group completed the } \\
\text { interview. External validity is difficult to } \\
\text { determine. The authors mentioned results } \\
\text { from prior research have not always been } \\
\text { duplicated. The interim analysis indicated }\end{array}$ \\
\hline
\end{tabular}




\begin{tabular}{|c|c|c|}
\hline & & $\begin{array}{l}\text { no significant difference of IA between the } \\
\text { two groups and thus the study was } \\
\text { terminated because of futility. The post hoc } \\
\text { analysis revealed there was a } 4.7 \text {-fold } \\
\text { reduction in definite or possible IA for } \\
\text { patients in the BIS group. }\end{array}$ \\
\hline $\begin{array}{l}\text { Population and } \\
\text { sample }\end{array}$ & $\begin{array}{l}\text { - Was the population identified? Was the sample } \\
\text { described in sufficient detail? } \\
\text { - Was the best possible sampling design used to } \\
\text { enhance the sample's representativeness? Were } \\
\text { sampling biases minimized? } \\
\text { - Was the sample size based on a power analysis? }\end{array}$ & $\begin{array}{l}\text { Patient population was identified with a } \\
\text { comparison of their key demographical } \\
\text { aspects between the two groups displayed in } \\
\text { Table } 1 \text {. Sufficient detail was given } \\
\text { regarding the participants. Sampling design } \\
\text { was fairly sound as participants were taken } \\
\text { from the University of Michigan Health } \\
\text { System but from three different facilities: a } \\
\text { main university hospital, a cardiovascular } \\
\text { center, and an ambulatory surgery center. } \\
\text { This diversity would aid in the researcher's } \\
\text { desire to have a generalized patient } \\
\text { population and not one of necessarily being } \\
\text { high-risk for IA. This diversity would seem } \\
\text { to help minimize sampling bias. The } \\
\text { original sample size calculations were based } \\
\text { on a power analysis. }\end{array}$ \\
\hline
\end{tabular}


Guide to an Overall Critique of a Quantitative Research Report

\begin{tabular}{|c|c|c|}
\hline $\begin{array}{l}\text { Aspect of the } \\
\text { Report }\end{array}$ & Critiquing Questions & Detailed Critiquing Guidelines \\
\hline $\begin{array}{l}\text { Data collection and } \\
\text { measurement }\end{array}$ & $\begin{array}{l}\text { - Were the operational and conceptual definitions } \\
\text { congruent? } \\
\text { - Were key variables measured using an appropriate } \\
\text { method (e.g., interviews, observations, and so on)? } \\
\text { Were specific instruments adequately described and } \\
\text { were they good choices, given the study population } \\
\text { and the variables being studied? } \\
\text { - Did the report provide evidence that the data } \\
\text { collection methods yielded data that were reliable, } \\
\text { valid and responsive? }\end{array}$ & $\begin{array}{l}\text { Conceptual definition is IA while the } \\
\text { operational definition is how it is measured, } \\
\text { which in this case was by the modified Brice } \\
\text { questionnaire. The key variable of IA was } \\
\text { measured first through the modified Brice } \\
\text { questionnaire and then if warranted, an } \\
\text { anesthesiologist committee member } \\
\text { conducted a more detailed interview. This is } \\
\text { an appropriate format in order to ascertain } \\
\text { IA. Although these were suitable choices, it } \\
\text { would have been beneficial for readers to } \\
\text { know more of the details regarding the } \\
\text { follow-up interview in cases of definite or } \\
\text { possible IA. The study ran into technical } \\
\text { issue where BIS values failed to be } \\
\text { generated. This was an issue for } 3,384 \text { of } \\
\text { the 9,460 patients in the BIS group. As a } \\
\text { result of this, the researchers decided to do a } \\
\text { post hoc analysis where this subset group } \\
\text { was used as a control group that received } \\
\text { neither BIS nor ETAC as the intervention. } \\
\text { Although this might question some of their }\end{array}$ \\
\hline
\end{tabular}




\begin{tabular}{|c|c|c|}
\hline & & $\begin{array}{l}\text { results, the transparency is appreciated. To } \\
\text { make the most out of the situation, the } \\
\text { researchers performed a post hoc analysis, } \\
\text { which provided important results as well. }\end{array}$ \\
\hline Procedures & $\begin{array}{l}\text { - If there was an intervention, was it adequately } \\
\text { described, and was it rigorously developed and } \\
\text { implemented? Did most participants allocated to the } \\
\text { intervention group actually receive it? Was there } \\
\text { evidence of intervention fidelity? } \\
\text { - Were data collected in a manner that minimized bias? } \\
\text { Were the staff who collected data appropriately } \\
\text { trained? }\end{array}$ & $\begin{array}{l}\text { Intervention of using the BIS monitor or } \\
\text { using the ETAC was well covered and } \\
\text { sufficiently described. Both protocols were } \\
\text { developed under straightforward reasoning } \\
\text { with values that most, if not all, anesthesia } \\
\text { providers were aware of and would not } \\
\text { dispute. Most of the participants in each } \\
\text { group received the intended protocol, as } \\
\text { described above, but there was still a } \\
\text { significant subset of the BIS group who did } \\
\text { not receive the protocol. Obviously, } \\
\text { intervention fidelity was significantly } \\
\text { hindered as a result of the technical } \\
\text { difficulty the BIS group encountered. } \\
\text { Data was collected without bias as the } \\
\text { postop interviewers and case reviewers were } \\
\text { all blinded to the patients' group } \\
\text { assignments. Additionally, if there was case } \\
\text { disagreement among the reviewers, the study } \\
\text { utilized a fourth expert independent reviewer } \\
\text { who reviews cases for the American Society }\end{array}$ \\
\hline
\end{tabular}




\begin{tabular}{|c|c|c|}
\hline & & $\begin{array}{l}\text { of Anesthesiologists. It is presumed that the } \\
\text { reviewers who collected the data were } \\
\text { trained appropriately as they were referred to } \\
\text { as expert reviewers. }\end{array}$ \\
\hline Data Analysis & $\begin{array}{l}\text { - Were analyses undertaken to address each research } \\
\text { - Wuestion or test each hypothesis? } \\
\text { level of measurement of the variables, number of } \\
\text { groups being compared, and assumptions of the } \\
\text { texts? } \\
\text { - Was a powerful analytic method used? (e.g., did the } \\
\text { analysis help to control for confounding variables)? } \\
\text { - Were type I and Type II errors avoided or } \\
\text { minimized? } \\
\text { In intervention studies, was an intention-to-treat } \\
\text { analysis performed? }\end{array}$ & $\begin{array}{l}\text { Numerous methods were performed to } \\
\text { analyze data. A linear regression r-squared } \\
\text { test was used to compare the incidence of } \\
\text { possible/definite awareness with the number } \\
\text { of paging alerts generated in each group. } \\
\text { One aspect of this study that was different } \\
\text { than other awareness studies was this study } \\
\text { only conducted one interview at } 30 \text { days to } \\
\text { determine if there was any potential } \\
\text { awareness (if there was, an additional } \\
\text { follow-up was conducted). The author's } \\
\text { post hoc analysis claimed that this single } \\
\text { interview was sufficient to identify clinically } \\
\text { applicable IA. Type I and II errors seem to } \\
\text { have been avoided as a null hypothesis was } \\
\text { never proposed. A modified intention-to- } \\
\text { treat analysis was done which showed } 11 \text { out } \\
\text { of 9,376 occurrences of definite awareness } \\
\text { in the ETAC group and } 8 \text { out of 9,460 } \\
\text { occurrences of definite awareness in the BIS } \\
\text { group. }\end{array}$ \\
\hline
\end{tabular}


Guide to an Overall Critique of a Quantitative Research Report

\begin{tabular}{|c|c|c|}
\hline $\begin{array}{l}\text { Aspect of the } \\
\text { Report }\end{array}$ & Critiquing Questions & Detailed Critiquing Guidelines \\
\hline $\begin{array}{l}\text { Data Analysis } \\
\text { (continued) }\end{array}$ & $\begin{array}{l}\text { - Were problems of missing values evaluated and } \\
\text { adequately addressed? }\end{array}$ & $\begin{array}{l}\text { The problem of missing values was addressed } \\
\text { but identified as either due to the death of the } \\
\text { patient or just failure to respond for the } \\
\text { interview request. Without an actual } \\
\text { breakdown to the numbers of each group, this } \\
\text { would not rate as being adequate. Another } \\
\text { issue was the aforementioned BIS monitor } \\
\text { technical error. Authors made most out of } \\
\text { situation by conducting a post hoc analysis. }\end{array}$ \\
\hline Findings & $\begin{array}{l}\text { Was information about statistical significance } \\
\text { presented? Was information about effect size and } \\
\text { precision of estimates (confidence intervals) } \\
\text { presented? } \\
\text { - Were the findings adequately summarized, with good } \\
\text { use of tables and figures? } \\
\text { - Were findings reported in a manner that facilitates a } \\
\text { meta-analysis, and with sufficient information } \\
\text { needed for EBP? }\end{array}$ & $\begin{array}{l}\text { Information about statistical significance was } \\
\text { presented numerous times in their data } \\
\text { analysis. Confidence intervals were } \\
\text { presented with outcome analysis regarding } \\
\text { the comparison of awareness between the BIS } \\
\text { and ETAC groups. Major findings were } \\
\text { presented in figures and tables; however, with } \\
\text { such limited number of actual occurrences of } \\
\text { awareness, the study might have been } \\
\text { enriched if it included a table with the actual } \\
\text { specifics regarding the accounts of awareness } \\
\text { as some other previous studies have done. } \\
\text { Interestingly, researchers determined this }\end{array}$ \\
\hline
\end{tabular}




\begin{tabular}{|c|c|c|}
\hline & & $\begin{array}{l}\text { type of comparative effectiveness trial for this } \\
\text { type of non-specialized patient population } \\
\text { will likely not produce definitive results } \\
\text { because of the sheer number of study } \\
\text { participants required. The authors mentioned } \\
\text { BIS monitor protocol probably reduces } \\
\text { awareness events as compared with routine } \\
\text { care without a protocol (BIS or ETAC). This } \\
\text { was deducted from their post hoc analysis. }\end{array}$ \\
\hline $\begin{array}{l}\text { Discussion } \\
\text { Interpretation of the } \\
\text { findings }\end{array}$ & $\begin{array}{l}\text { - Were all major findings interpreted and discussed } \\
\text { within the context of prior research and/or the } \\
\text { study's conceptual framework? } \\
\text { - Were casual inferences, if any, justified? } \\
\text { - Was the issue of clinical significance discussed? } \\
\text { - Were interpretations well-founded and consistent } \\
\text { with the study's limitations? } \\
\text { Did the report address the issue of the } \\
\text { generalizability of the findings? }\end{array}$ & $\begin{array}{l}\text { Findings from primary and post hoc analysis } \\
\text { were both compared and contrasted to prior } \\
\text { research and clinical significance discussed. } \\
\text { Researchers chose to interview patients once } \\
\text { (due to the sheer number of patients) and they } \\
\text { picked it at 28-30 days because this is when } \\
\text { they could identify the highest clinically } \\
\text { significant awareness episodes. Researchers } \\
\text { stated interval was validated based on their } \\
\text { post hoc analysis. Researchers acknowledged } \\
\text { their limitations (mainly the BIS monitor } \\
\text { technical difficulty) and initiated secondary } \\
\text { post hoc analyses with their data. } \\
\text { Acknowledged they had inadequate numbers } \\
\text { to definitively state if there was a difference } \\
\text { in awareness incidence rate between the BIS } \\
\text { and ETAC groups. Discussed }\end{array}$ \\
\hline
\end{tabular}




\begin{tabular}{|c|c|c|}
\hline & & $\begin{array}{l}\text { generalizability of results. Due to the } \\
\text { infrequency of IA in this type of } \\
\text { unspecialized patient population, future } \\
\text { research would need to use this information } \\
\text { in choosing their protocols and sample size. }\end{array}$ \\
\hline $\begin{array}{l}\text { Implications/ } \\
\text { recommendations }\end{array}$ & $\begin{array}{l}\text { Did the researchers discuss the implications of the } \\
\text { study for clinical practice or further research-and } \\
\text { were those implications reasonable and complete? }\end{array}$ & $\begin{array}{l}\text { The researchers acknowledged that their } \\
\text { study did not have enough numbers to } \\
\text { precisely answer the difference in definite } \\
\text { awareness between the } 2 \text { protocol groups. } \\
\text { They do say that the sheer low number of IA } \\
\text { occurrences is something that needs to be } \\
\text { taken into consideration if future trials are to } \\
\text { be done. Based on their results, these are } \\
\text { reasonable conclusions. }\end{array}$ \\
\hline $\begin{array}{l}\text { General Issues } \\
\text { Presentation }\end{array}$ & $\begin{array}{l}\text { - Was the report well-written, organized, and } \\
\text { sufficiently detailed for critical analysis? } \\
\text { In intervention studies, was a CONSORT flowchart } \\
\text { provided to show the flow of participants in the } \\
\text { study? }\end{array}$ & $\begin{array}{l}\text { Report well-written and organized. } \\
\text { Appropriate details regarding all findings of } \\
\text { primary and secondary outcomes were } \\
\text { included. Statistical tests and comparisons } \\
\text { were reported. CONSORT flowchart was } \\
\text { utilized in order to see how study participants } \\
\text { progressed along in the trial. }\end{array}$ \\
\hline
\end{tabular}

\section{Guide to an Overall Critique of a Quantitative Research Report}




\begin{tabular}{|c|c|c|}
\hline \multicolumn{3}{|l|}{ Report } \\
\hline $\begin{array}{l}\text { General Issues } \\
\text { Presentation } \\
\text { (continued) }\end{array}$ & $\begin{array}{l}\text { - Was the report written in a manner that makes the } \\
\text { findings accessible to practicing nurses? }\end{array}$ & $\begin{array}{l}\text { Study is published in a way that makes it } \\
\text { easily accessible for anesthesia practitioners } \\
\text { to comprehend and apply to practice. }\end{array}$ \\
\hline $\begin{array}{l}\text { Researcher } \\
\text { credibility }\end{array}$ & $\begin{array}{l}\text { Do the researchers' clinical, substantive, or } \\
\text { methodologic qualifications and experience enhance } \\
\text { confidence in the findings and their interpretation? }\end{array}$ & $\begin{array}{l}\text { Researchers' credentials along with their } \\
\text { current positions are listed on the front page } \\
\text { of the study. Authors' diverse backgrounds } \\
\text { from medical student to Chief of Anesthesia } \\
\text { Service does enhance confidence in the } \\
\text { study’s findings and interpretations. Other } \\
\text { authors in the study included a professor, } \\
\text { statistician, research specialist/statistician, } \\
\text { and an associate chair of faculty affairs. }\end{array}$ \\
\hline $\begin{array}{l}\text { Summary } \\
\text { assessment }\end{array}$ & $\begin{array}{l}\text { - Despite any limitations, do the study findings appear } \\
\text { to be valid-do you have confidence in the truth } \\
\text { value of the results? } \\
\text { - Does the study contribute any meaningful evidence } \\
\text { that can be used in nursing practice or that is useful } \\
\text { to the nursing discipline? }\end{array}$ & $\begin{array}{l}\text { Despite the limitations causing additional } \\
\text { post hoc analyses, findings appear to be valid } \\
\text { and there is no reason to doubt the validity. } \\
\text { There are no concrete findings that can be } \\
\text { translated into EBP as a result of this study. } \\
\text { Authors do state that it is probable that BIS } \\
\text { monitoring compared with routine care } \\
\text { without a protocol reduces awareness. }\end{array}$ \\
\hline
\end{tabular}

*Reprinted with permission from the editor of D. Polit and C. Beck (2017). Nursing Research. Generating and assessing evidence for nursing practice $\left(10^{\text {th }}\right.$ ed.). Wolters Kluwer. 


\section{Guide to an Overall Critique of a Quantitative Research Report}

Table C6

Avidan, M.S., Jacobsohn, E., Glick, D., Burnside, B., Zhang, L., Villafranca, A.,...Mashour, G. (2011). Prevention of intraoperative awareness in a high-risk surgical population. New England Journal of Medicine, 367(7), 591-600.

\begin{tabular}{|c|c|c|}
\hline $\begin{array}{l}\text { Aspect of the } \\
\text { Report }\end{array}$ & Critiquing Questions & Detailed Critiquing Guidelines \\
\hline Title & $\begin{array}{l}\text { - Is the title a good one, succinctly suggesting key } \\
\text { variables and the study population? }\end{array}$ & $\begin{array}{l}\text { Title is very good and informs the readers of } \\
\text { all key variables. }\end{array}$ \\
\hline Abstract & $\begin{array}{l}\text { Did the abstract clearly and concisely summarize the } \\
\text { main features of the report (problem, methods, } \\
\text { results, conclusions)? }\end{array}$ & $\begin{array}{l}\text { Abstract gave all the critical features of each } \\
\text { of the main parts (problem, methods, results, } \\
\text { conclusions) with important details. }\end{array}$ \\
\hline $\begin{array}{l}\text { Introduction } \\
\text { Statement of the } \\
\text { problem }\end{array}$ & $\begin{array}{l}\text { - Was the problem stated unambiguously, and was it } \\
\text { easy to identify? } \\
\text { - Is the problem statement build a persuasive argument } \\
\text { for the new study? } \\
\text { - Was there a good match between the research } \\
\text { problem and the methods used -that is, was a } \\
\text { quantitative approach appropriate? }\end{array}$ & $\begin{array}{l}\text { Problem stated clearly with details of } \\
\text { potential problems arising as well as some of } \\
\text { current methods and knowledge used to } \\
\text { prevent them. The problem statement } \\
\text { definitely builds an argument for this study. } \\
\text { Several of the authors had worked on a } \\
\text { previous study, which was comparing the } \\
\text { same intervention (BIS and its efficacy in } \\
\text { preventing IA); however, they chose to } \\
\text { address some of the limitations of their } \\
\text { previous study and conduct another study } \\
\text { but with a larger sample and as a multi- }\end{array}$ \\
\hline
\end{tabular}




\begin{tabular}{|c|c|c|}
\hline & & $\begin{array}{l}\text { center approach. As the results show }<1 \% \\
\text { of patients may have IA, it is clear that a } \\
\text { quantitative approach is needed. }\end{array}$ \\
\hline $\begin{array}{l}\text { Hypotheses or } \\
\text { research questions }\end{array}$ & $\begin{array}{l}\text { - Were research questions and/or hypotheses explicitly } \\
\text { stated? If not, was their absence justified? } \\
\text { - Were questions and hypotheses appropriately } \\
\text { worded, with clear specification of key variables and } \\
\text { the study population? } \\
\text { - Were the questions/hypotheses consistent with } \\
\text { existing knowledge? }\end{array}$ & $\begin{array}{l}\text { Authors included two hypotheses. Null } \\
\text { hypothesis was that the BIS protocol was not } \\
\text { superior to the ETAC protocol in preventing } \\
\text { IA. Alternative hypothesis was that the BIS } \\
\text { protocol is superior in preventing IA. Study } \\
\text { specifically described both the patient } \\
\text { population as well as the important variables } \\
\text { of the study. Study questions targeted was } \\
\text { based on previous similar studies and was } \\
\text { therefore consistent with existing } \\
\text { knowledge. }\end{array}$ \\
\hline Literature review & $\begin{array}{l}\text { - Was the literature review up-to-date and based } \\
\text { mainly on primary sources? } \\
\text { - Did the review provide a state-of-the-art synthesis of } \\
\text { evidence on the problem? } \\
\text { - Did the literature review provide a strong basis for } \\
\text { the new study? }\end{array}$ & $\begin{array}{l}\text { Although there was not a literature review } \\
\text { section, study reported some previous study } \\
\text { results, which helped guide the hypotheses } \\
\text { and study methodology. A couple of studies } \\
\text { had somewhat conflicting results, the authors } \\
\text { attempted to address these with some slight } \\
\text { modifications. The authors did present their } \\
\text { evidence of the problem of awareness from } \\
\text { previous studies and that influenced how this } \\
\text { study was formulated. }\end{array}$ \\
\hline
\end{tabular}


Guide to an Overall Critique of a Quantitative Research Report

\begin{tabular}{|c|c|c|}
\hline Aspect of the Report & Critiquing Questions & Detailed Critiquing Guidelines \\
\hline $\begin{array}{l}\text { Conceptual/theoretical } \\
\text { framework }\end{array}$ & $\begin{array}{l}\text { - Were key concepts adequately defined conceptually? } \\
\text { - Was a conceptual/theoretical framework } \\
\text { articulated-and, if so, was it appropriate? If not, is } \\
\text { the absence of a framework justified? } \\
\text { - Were the questions/hypotheses consistent with the } \\
\text { framework? }\end{array}$ & $\begin{array}{l}\text { Key concepts were explained thoroughly. } \\
\text { The major concept being IA and this is } \\
\text { explained in the first sentence of the study. } \\
\text { Other concepts were explained or easy to } \\
\text { interpret. In this type of study, a theoretical } \\
\text { framework seems unnecessary to be stated. } \\
\text { The hypotheses fit with the design of the } \\
\text { research and were consistent with the overall } \\
\text { goal. }\end{array}$ \\
\hline $\begin{array}{l}\text { Method } \\
\text { Protection of human } \\
\text { rights }\end{array}$ & $\begin{array}{l}\text { - Were appropriate procedures used to safe-guard the } \\
\text { rights of study participants? } \\
\text { - Was the study externally reviewed by an IRB/ethics } \\
\text { review board? } \\
\text { - Was the study designed to minimize risks and } \\
\text { maximize benefits to participants? }\end{array}$ & $\begin{array}{l}\text { Appropriate procedures were used to ensure } \\
\text { the rights of study participants as human } \\
\text { studies committees at the three universities } \\
\text { approved the study. Guidelines of the } \\
\text { Consolidated Standards of Reporting Trials } \\
\text { were followed. Although there was no } \\
\text { mention of an IRB/ethics board, it is } \\
\text { probably safe to assume that the university } \\
\text { committees operated in a similar fashion. } \\
\text { Overall, this study leaned towards } \\
\text { minimizing risks to the patients as the } \\
\text { anesthesia providers were not given any } \\
\text { instructions on how to implement or alter } \\
\text { their anesthesia plans. Patients in the BIS }\end{array}$ \\
\hline
\end{tabular}




\begin{tabular}{|c|c|c|}
\hline & & $\begin{array}{l}\text { protocol benefited from having an extra } \\
\text { monitoring device in their care while those } \\
\text { in the ETAC group did not. Additionally, } \\
\text { since the patients were assigned to the } \\
\text { groups through a randomization process, that } \\
\text { was another safeguard to try and eliminate } \\
\text { any bias. }\end{array}$ \\
\hline Research design & $\begin{array}{l}\text { - Was the most rigorous design used, given the study } \\
\text { purpose? } \\
\text { - Were appropriate comparisons made to enhance } \\
\text { interpretability of the findings? } \\
\text { - Was the number of data collection points } \\
\text { appropriate? } \\
\text { Did the design minimize biases and threats to the } \\
\text { internal, construct, and external validity of the study } \\
\text { (e.g., was blinding used, was attrition minimized)? }\end{array}$ & $\begin{array}{l}\text { Study design was very rigorous given the } \\
\text { purpose and researchers chose to do a } \\
\text { prospective, randomization, multi-center } \\
\text { trial. The number of data collection points } \\
\text { was appropriate although it would not have } \\
\text { been wrong to have an additional interview } \\
\text { instead of just at within } 72 \text { hours of surgery } \\
\text { and then again } 30 \text { days after extubation. } \\
\text { There is always potential for some internal } \\
\text { validity issues in a study regarding } \\
\text { awareness. If the anesthesia provider is } \\
\text { aware that this type of study is occurring, } \\
\text { they may subconsciously try and change } \\
\text { their anesthetic plan to prevent possible } \\
\text { awareness. Construct validity is not an issue } \\
\text { as the Brice questionnaire is frequently used } \\
\text { to try and identify IA. External validity is } \\
\text { always a concern and a reason why this } \\
\text { study has been done in the past to see if the }\end{array}$ \\
\hline
\end{tabular}




\begin{tabular}{|l|l|l|}
\hline & $\mid \begin{array}{l}\text { results can be duplicated or if they were } \\
\text { simply unique to that particular study } \\
\text { sample. Aside from this, the study did } \\
\text { attempt to minimize biases as there was } \\
\text { randomization; all parties were blinded } \\
\text { (except for the anesthesia providers), and } \\
\text { attrition was minimized as 98.3\% of patients } \\
\text { completed at least one interview and 93.2\% } \\
\text { completed both. }\end{array}$ \\
\hline $\begin{array}{l}\text { Population and } \\
\text { sample }\end{array}$ & $\begin{array}{l}\text { Was the population identified? Was the sample } \\
\text { described in sufficient detail? } \\
\text { Was the best possible sampling design used to } \\
\text { enhance the sample's representativeness? Were } \\
\text { sampling biases minimized? } \\
\text { Was the sample size based on a power analysis? }\end{array}$ & $\begin{array}{l}\text { The population's demographics were } \\
\text { identified in Table 1 and in the text with } \\
\text { sufficient detail. Pre-randomization } \\
\text { sampling design worked very well as } \\
\text { according to the table and p-values, the } \\
\text { demographics between the two groups were } \\
\text { very similar. As this study was conducted at } \\
\text { three separate centers, sampling biases were } \\
\text { minimized to the extent that was possible. } \\
\text { The sample size was based on a power } \\
\text { analysis. }\end{array}$ \\
\hline
\end{tabular}

\section{Guide to an Overall Critique of a Quantitative Research Report}
Aspect of the
Critiquing Questions 
Report

\begin{tabular}{|c|c|c|}
\hline $\begin{array}{l}\text { Data collection and } \\
\text { measurement }\end{array}$ & $\begin{array}{l}\text { - Were the operational and conceptual definitions } \\
\text { congruent? } \\
\text { - Were key variables measured using an appropriate } \\
\text { method (e.g., interviews, observations, and so on)? } \\
\text { - Were specific instruments adequately described and } \\
\text { were they good choices, given the study population } \\
\text { and the variables being studied? } \\
\text { - Did the report provide evidence that the data } \\
\text { collection methods yielded data that were reliable, } \\
\text { valid and responsive? }\end{array}$ & $\begin{array}{l}\text { Operational and conceptual definitions are } \\
\text { related, but not congruent. The operational } \\
\text { definition is the Brice questionnaire, which } \\
\text { is the instrument used to measure the } \\
\text { conceptual definition of IA. BIS has its own } \\
\text { scale that was measured for the BIS group } \\
\text { and the ETAC was measured for both } \\
\text { groups. The Brice questionnaire is an } \\
\text { appropriate instrument to use when trying to } \\
\text { ascertain if a patient experienced IA. It was } \\
\text { not described in detail in the study. As } \\
\text { experts who did not know which group the } \\
\text { patients belonged to collected data } \\
\text { independently, it assured the responses } \\
\text { would be valid and reliable. Additionally, if } \\
\text { there was a question on whether the patient } \\
\text { response was a case of awareness or not, a } \\
\text { fourth expert reviewer from the Anesthesia } \\
\text { Awareness Registry of the American Society } \\
\text { of Anesthesiologists made the final decision. }\end{array}$ \\
\hline Procedures & $\begin{array}{l}\text { - If there was an intervention, was it adequately } \\
\text { described, and was it rigorously developed and } \\
\text { implemented? Did most participants allocated to the } \\
\text { intervention group actually receive it? Was there } \\
\text { evidence of intervention fidelity? }\end{array}$ & $\begin{array}{l}\text { The intervention was either the use of BIS or } \\
\text { not. Both groups had the ETAC data } \\
\text { available to them. BIS was described in } \\
\text { detail along with what the protocol for the }\end{array}$ \\
\hline
\end{tabular}




\begin{tabular}{|c|c|c|}
\hline & $\begin{array}{l}\text { Were data collected in a manner that minimized bias? } \\
\text { Were the staff who collected data appropriately } \\
\text { trained? }\end{array}$ & $\begin{array}{l}\text { group consisted of. For both groups, the } \\
\text { vast majority of patients received their } \\
\text { designated protocol. There was definitely } \\
\text { evidence of intervention fidelity as patients } \\
\text { in each group who did not receive the } \\
\text { protocol had legitimate reasons or did not } \\
\text { meet the inclusion criteria after the } \\
\text { randomization. As the experts who collected } \\
\text { the data did not know the assigned groups of } \\
\text { the patients, this definitely would minimize } \\
\text { bias. Although we cannot say for sure, staff } \\
\text { who collected the data were appropriately } \\
\text { trained, we would assume they were since } \\
\text { they were “experts.” }\end{array}$ \\
\hline Data Analysis & $\begin{array}{l}\text { - Were analyses undertaken to address each research } \\
\text { question or test each hypothesis? } \\
\text { Were appropriate statistical methods used, given the } \\
\text { level of measurement of the variables, number of } \\
\text { groups being compared, and assumptions of the } \\
\text { texts? } \\
\text { - Was a powerful analytic method used? (e.g., did the } \\
\text { analysis help to control for confounding variables)? } \\
\text { - Were type I and Type II errors avoided or } \\
\text { minimized? } \\
\text { In intervention studies, was an intention-to-treat } \\
\text { analysis performed? }\end{array}$ & $\begin{array}{l}\text { Statistical analyses were done on the null } \\
\text { and alternative hypothesis and surprisingly; } \\
\text { the results were contrary to the alternative } \\
\text { hypothesis. Chi-square, Fisher's exact, } \\
\text { unpaired Mann-Whitney U, unpaired } \\
\text { Student's t-test and other statistical tests } \\
\text { were conducted. These were all appropriate } \\
\text { choices given the data and groups that were } \\
\text { being compared. Although the anesthesia } \\
\text { providers were aware of which group the } \\
\text { patients were in, no one else had this } \\
\text { knowledge. Along with the randomization }\end{array}$ \\
\hline
\end{tabular}




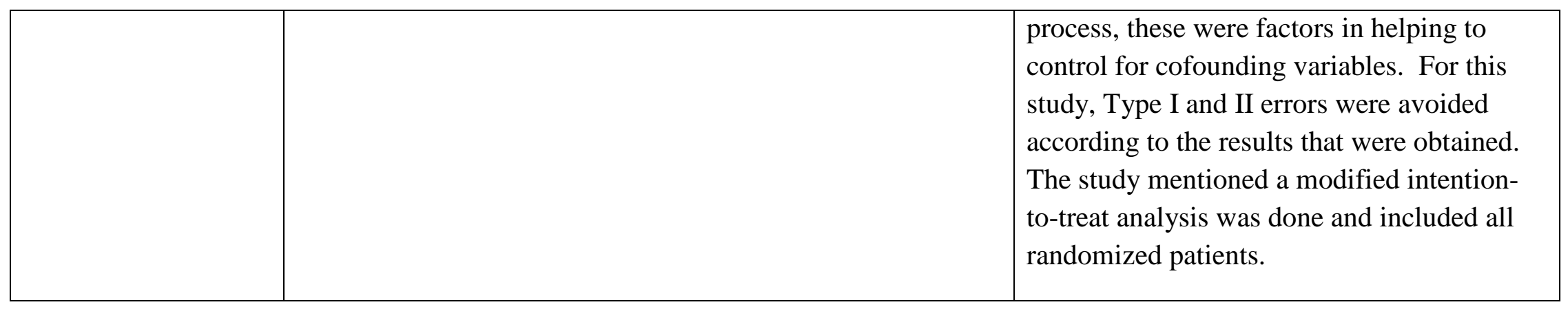

\section{Guide to an Overall Critique of a Quantitative Research Report}

\begin{tabular}{|c|c|c|}
\hline $\begin{array}{l}\text { Aspect of the } \\
\text { Report }\end{array}$ & Critiquing Questions & Detailed Critiquing Guidelines \\
\hline $\begin{array}{l}\text { Data Analysis } \\
\text { (continued) }\end{array}$ & $\begin{array}{l}\text { - Were problems of missing values evaluated and } \\
\text { adequately addressed? }\end{array}$ & $\begin{array}{l}\text { The missing values (i.e., patients) from the } \\
\text { study were both evaluated and addressed. It } \\
\text { is almost inevitable that studies of this } \\
\text { magnitude end up having some missing } \\
\text { values, but this study had a very low attrition } \\
\text { rate and did discuss the reason. }\end{array}$ \\
\hline Findings & $\begin{array}{l}\text { Was information about statistical significance } \\
\text { presented? Was information about effect size and } \\
\text { precision of estimates (confidence intervals) } \\
\text { presented? } \\
\text { - Were the findings adequately summarized, with good } \\
\text { use of tables and figures? } \\
\text { - Were findings reported in a manner that facilitates a }\end{array}$ & $\begin{array}{l}\text { The study computed } p \text {-values when } \\
\text { comparing the demographics of the BIS and } \\
\text { ETAC groups and indicated values that were } \\
\text { less than } 0.05 \text { indicated statistical } \\
\text { significance. Study utilized several other } \\
\text { statistical tests such as the Fisher's exact test, }\end{array}$ \\
\hline
\end{tabular}




\begin{tabular}{|c|c|c|}
\hline & $\begin{array}{l}\text { meta-analysis, and with sufficient information } \\
\text { needed for EBP? }\end{array}$ & $\begin{array}{l}\text { chi-square test with Yates' correction, } \\
\text { Student's t-test, and the Mann-Whitney U test } \\
\text { and confidence intervals were reported. } \\
\text { Findings were placed into a table, which } \\
\text { compared episodes of awareness between the } \\
\text { two groups along with statistical analysis. } \\
\text { There was good use of a table to compare the } \\
\text { demographics between the two groups in a } \\
\text { statistical manner. There is not sufficient } \\
\text { information here for a meta-analysis or is it } \\
\text { enough to be considered EBP. }\end{array}$ \\
\hline $\begin{array}{l}\text { Discussion } \\
\text { Interpretation of the } \\
\text { findings }\end{array}$ & $\begin{array}{l}\text { - Were all major findings interpreted and discussed } \\
\text { within the context of prior research and/or the } \\
\text { study's conceptual framework? } \\
\text { - Were casual inferences, if any, justified? } \\
\text { - Was the issue of clinical significance discussed? } \\
\text { - Were interpretations well-founded and consistent } \\
\text { with the study's limitations? } \\
\text { Did the report address the issue of the } \\
\text { generalizability of the findings? }\end{array}$ & $\begin{array}{l}\text { Since this study's primary research goal was } \\
\text { influenced by previous studies, results were } \\
\text { discussed and compared with prior studies. } \\
\text { Results were interpreted and findings } \\
\text { contrasted with some of prior results. A } \\
\text { potential causal inference in this type of study } \\
\text { is that since the anesthesia providers know } \\
\text { that the patient is in a study about awareness, } \\
\text { they may go above and beyond what they } \\
\text { normally do to try and prevent that particular } \\
\text { patient from having any awareness issue. } \\
\text { The authors did not mention this possibility. } \\
\text { The authors did discuss clinical significance } \\
\text { such as the power analysis they performed to } \\
\text { project their sample size. The interpretations }\end{array}$ \\
\hline
\end{tabular}




\begin{tabular}{|c|c|c|}
\hline & & $\begin{array}{l}\text { of results were consistent with the limitations } \\
\text { and the authors did discuss some of the } \\
\text { generalizability of their findings in the } \\
\text { discussion section. In particular, they stated } \\
\text { their findings should not be applied to a } \\
\text { patient population that goes beyond what they } \\
\text { researched (high-risk patients undergoing } \\
\text { general anesthesia). }\end{array}$ \\
\hline $\begin{array}{l}\text { Implications/ } \\
\text { recommendations }\end{array}$ & $\begin{array}{l}\text { Did the researchers discuss the implications of the } \\
\text { study for clinical practice or further research-and } \\
\text { were those implications reasonable and complete? }\end{array}$ & $\begin{array}{l}\text { In their discussion, the authors seemed to } \\
\text { conclude that an ETAC-based protocol would } \\
\text { be an effective IA preventative measure for } \\
\text { high-risk patients undergoing general } \\
\text { anesthesia. Although this may be reasonable } \\
\text { according to their study and its results, it does } \\
\text { seem to be incomplete at this time since all } \\
\text { studies on this topic are not in agreement. It } \\
\text { would seem that additional research would be } \\
\text { warranted. }\end{array}$ \\
\hline $\begin{array}{l}\text { General Issues } \\
\text { Presentation }\end{array}$ & $\begin{array}{l}\text { - Was the report well-written, organized, and } \\
\text { sufficiently detailed for critical analysis? } \\
\text { - In intervention studies, was a CONSORT flowchart } \\
\text { provided to show the flow of participants in the } \\
\text { study? }\end{array}$ & $\begin{array}{l}\text { Report was well-written and organized. It } \\
\text { was detailed and is an acceptable candidate } \\
\text { for critical analysis. A CONSORT flowchart } \\
\text { was used to show the flow of participants. }\end{array}$ \\
\hline
\end{tabular}


Guide to an Overall Critique of a Quantitative Research Report

\begin{tabular}{|c|c|c|}
\hline $\begin{array}{l}\text { Aspect of the } \\
\text { Report }\end{array}$ & Critiquing Questions & Detailed Critiquing Guidelines \\
\hline $\begin{array}{l}\text { General Issues } \\
\text { Presentation } \\
\text { (continued) }\end{array}$ & $\begin{array}{l}\text { - Was the report written in a manner that makes the } \\
\text { findings accessible to practicing nurses? }\end{array}$ & $\begin{array}{l}\text { Practicing anesthesia providers can definitely } \\
\text { interpret and choose to apply the findings to } \\
\text { practice if they choose to. }\end{array}$ \\
\hline $\begin{array}{l}\text { Researcher } \\
\text { credibility }\end{array}$ & $\begin{array}{l}\text { - Do the researchers' clinical, substantive, or } \\
\text { methodologic qualifications and experience enhance } \\
\text { confidence in the findings and their interpretation? }\end{array}$ & $\begin{array}{l}\text { Beyond credentials as listed in the by-line, } \\
\text { there is not much stated about the } \\
\text { researchers' qualifications and experiences. } \\
\text { Several of the researchers worked on } \\
\text { previous awareness studies. Experts were } \\
\text { utilized to conduct parts of the studies. }\end{array}$ \\
\hline $\begin{array}{l}\text { Summary } \\
\text { assessment }\end{array}$ & $\begin{array}{l}\text { - Despite any limitations, do the study findings appear } \\
\text { to be valid-do you have confidence in the truth } \\
\text { value of the results? } \\
\text { - Does the study contribute any meaningful evidence } \\
\text { that can be used in nursing practice or that is useful } \\
\text { to the nursing discipline? }\end{array}$ & $\begin{array}{l}\text { Findings appear to be valid and there does not } \\
\text { seem to be reason to not believe in the truth } \\
\text { value of results. Findings actually } \\
\text { contradicted the stated hypothesis. The } \\
\text { results of this study have some value to } \\
\text { anesthesia providers as this is a more } \\
\text { extensive and larger study than a previous } \\
\text { one with a very similar demographic target. } \\
\text { Probably not enough to be considered EBP } \\
\text { and additional research should be continued. }\end{array}$ \\
\hline
\end{tabular}

*Reprinted with permission from the editor of D. Polit and C. Beck (2017). Nursing Research. Generating and assessing evidence for nursing practice $\left(10^{\text {th }}\right.$ ed.). Wolters Kluwer. 


\section{Guidelines for Critiquing Literature Reviews}

Table C7

Forman, S. (2006). Awareness during general anesthesia: concepts and controversies. Seminars In Anesthesia, Perioperative Medicine \& Pain, 25(4), 211-218.

\section{Critiquing Questions}

Critique Responses

1. Is the review thorough — does it include all major studies on the $\quad$ The review is fairly thorough and includes some of the topic? Does it include recent research (studies published within previous 2-3 years)? Are studies from other related disciplines included, if appropriate?

major studies that were published in the preceding 2-3

years. It does include studies from other disciplines, as they were appropriate for some of the physiology content.

2. Does the review rely mainly on primary source research articles? Are the articles from peer-reviewed journals?

The review does primarily consist of articles from peerreviewed journals. It does include a few primary source research articles as well.

3. Is the review merely a summary of existing work, or does it critically appraise and compare key studies? Does the review identify important gaps in the literature?

For the most part, this review is a summary of the existing work. There is some comparison of similar studies, but just regarding the use of brain monitors. The review does identify the lack of efficacy data on brain monitors and that additional data is required. It identifies that current patients need a more definitive solution and the author offers his recommendation.

4. Is the review well organized? Is the development of ideas clear? analyzed is pertinent to the overall review topic. Ideas are 


\begin{tabular}{|l|l|}
\hline 5. $\begin{array}{l}\text { Does the review use appropriate language, suggesting the } \\
\text { tentativeness of prior findings? Is the review objective? Does } \\
\text { the author paraphrase, or is there an overreliance on quotes } \\
\text { from original sources? }\end{array}$ & $\begin{array}{l}\text { The review does use appropriate language and } \\
\text { consistently offers reasons and rationale to compare } \\
\text { results of prior studies. The review is objective overall. } \\
\text { The author does a very good job of paraphrasing and only } \\
\text { uses a few quotes in the review. }\end{array}$ \\
\hline $\begin{array}{l}\text { 6. If the review is part of a research report for a new study, does } \\
\text { the review support the need for the study? }\end{array}$ & N/A \\
\hline $\begin{array}{l}\text { If it is a review designed to summarize evidence for clinical } \\
\text { practice, does the review draw reasonable conclusions about } \\
\text { practice implications? }\end{array}$ & $\begin{array}{l}\text { The review certainly makes some reasonable conclusions } \\
\text { with implications for practice for anesthesia providers. } \\
\text { They advise that it is the responsibility of the provider to } \\
\text { perform a thorough pre-anesthetic evaluation in order to } \\
\text { ascertain the risk for IA. They offer suggestions in } \\
\text { minimizing the risk for IA. Finally, they discuss what } \\
\text { should be done in the event of a case of IA. }\end{array}$ \\
\hline
\end{tabular}

*Reprinted with permission from the editor of D. Polit and C. Beck (2017). Nursing Research. Generating and assessing evidence for nursing practice $\left(10^{\text {th }}\right.$ ed.). Wolters Kluwer. 


\section{Guidelines for Critiquing Literature Reviews}

Table C8

Apfelbaum, J.L., Arens, J.F., Cole, D.J., Connis, R. T., Domino, K.B., Drummond,J.C.,...Todd, M.M. (2006). Practice advisory for intraoperative awareness and brain function monitoring: a report by the american society of anesthesiologists task force on intraoperative awareness. Anesthesiology, 104(4), 847-864.

\section{Critiquing Questions}

Critique Responses

1. Is the review thorough-does it include all major studies on the topic? Does it include recent research (studies published within previous 2-3 years)? Are studies from other related disciplines included, if appropriate?

2. Does the review rely mainly on primary source research articles? Are the articles from peer-reviewed journals?

3. Is the review merely a summary of existing work, or does it critically appraise and compare key studies? Does the review identify important gaps in the literature?

The practice advisory was very thorough and used extensive research that was conducted recently and farther in the past. Numerous articles from other disciplines were referenced and used appropriately.

The advisory was primarily based on articles from peerreviewed journals but still utilized a significant number of primary source research. All the articles came from peerreviewed journals.

The advisory definitely summarizes a lot of existing work in order to produce its recommendations. However, it took an additional step in soliciting opinions from varied groups through surveys, forums, and direct consultants.

4. Is the review well organized? Is the development of ideas clear?

The advisory was organized, detailed, and suitable for analysis. The descriptions of the methods, findings, and interpretations were clear and helped with the 


\begin{tabular}{|c|c|}
\hline & development of the ideas. \\
\hline $\begin{array}{l}\text { 5. Does the review use appropriate language, suggesting the } \\
\text { tentativeness of prior findings? Is the review objective? Does } \\
\text { the author paraphrase, or is there an overreliance on quotes } \\
\text { from original sources? }\end{array}$ & $\begin{array}{l}\text { The advisory certainly uses appropriate language to } \\
\text { discuss its findings and results. Quite often, there is a } \\
\text { disagreement of opinion between the consultants and } \\
\text { ASA members and it is explicitly stated when that occurs. } \\
\text { The advisory does seem to have objective findings based } \\
\text { on the attempt at getting consensus before furnishing their } \\
\text { opinion. However, as stated in the advisory, there were a } \\
\text { certain number of consultants and task force members } \\
\text { who acknowledged having received funds from brain } \\
\text { function monitor companies so there may be some bias. } \\
\text { The advisory does not utilize any quotes from original } \\
\text { sources and does a credible job in paraphrasing original } \\
\text { sources. }\end{array}$ \\
\hline $\begin{array}{l}\text { 6. If the review is part of a research report for a new study, does } \\
\text { the review support the need for the study? }\end{array}$ & N/A \\
\hline $\begin{array}{l}\text { 7. If it is a review designed to summarize evidence for clinical } \\
\text { practice, does the review draw reasonable conclusions about } \\
\text { practice implications? }\end{array}$ & $\begin{array}{l}\text { The advisory offers recommendations about practice } \\
\text { implications. They describe what to look for in a } \\
\text { preoperative evaluation, risk factors associated with IA, } \\
\text { the utility of brain function monitors, and suggestions for } \\
\text { the prevention of IA. }\end{array}$ \\
\hline
\end{tabular}


*Reprinted with permission from the editor of D. Polit and C. Beck (2017). Nursing Research. Generating and assessing evidence for nursing practice $\left(10^{\text {th }}\right.$ ed.). Wolters Kluwer. 


\section{Guidelines for Critiquing Literature Reviews}

Table C9

Kotsovolis, G., \& Komninos, G. (2009). Awareness during anesthesia: how sure can we be that the patient is sleeping indeed? Hippokratia, 13(2), 83-89.

\begin{tabular}{|c|c|}
\hline Critiquing Questions & Critique Responses \\
\hline $\begin{array}{l}\text { 1. Is the review thorough-does it include all major studies on the } \\
\text { topic? Does it include recent research (studies published within } \\
\text { previous 2-3 years)? Are studies from other related disciplines } \\
\text { included, if appropriate? }\end{array}$ & $\begin{array}{l}\text { Review is fairly thorough. It does contain several of the } \\
\text { major studies that have been performed on the topic of IA. } \\
\text { It lacks recent research as it contains just a few studies } \\
\text { from two to three years prior to this publishing. Studies } \\
\text { from other disciplines that were included were appropriate } \\
\text { and had implications for different parts of the review. }\end{array}$ \\
\hline $\begin{array}{l}\text { 2. Does the review rely mainly on primary source research } \\
\text { articles? Are the articles from peer-reviewed journals? }\end{array}$ & $\begin{array}{l}\text { Review does rely mostly on primary source research } \\
\text { articles from peer-reviewed journals. }\end{array}$ \\
\hline $\begin{array}{l}\text { 3. Is the review merely a summary of existing work, or does it } \\
\text { critically appraise and compare key studies? Does the review } \\
\text { identify important gaps in the literature? }\end{array}$ & $\begin{array}{l}\text { Review is primarily a summary of existing work. Authors } \\
\text { compared and contrasted results, but for the most part, } \\
\text { just summarized past work and blended data together to } \\
\text { formulate conclusions regarding the state of IA and } \\
\text { methods to combat it. }\end{array}$ \\
\hline $\begin{array}{l}\text { 4. Is the review well organized? Is the development of ideas } \\
\text { clear? }\end{array}$ & $\begin{array}{l}\text { Review is well organized as it covers all factors related to } \\
\text { IA, from what is IA and how it compares to consciousness } \\
\text { to risk factors to prevention strategies. The development }\end{array}$ \\
\hline
\end{tabular}




\begin{tabular}{|c|c|}
\hline & of ideas is clear and logical. \\
\hline $\begin{array}{l}\text { 5. Does the review use appropriate language, suggesting the } \\
\text { tentativeness of prior findings? Is the review objective? Does } \\
\text { the author paraphrase, or is there an overreliance on quotes } \\
\text { from original sources? }\end{array}$ & $\begin{array}{l}\text { Authors do not seem to indicate any tentativeness of prior } \\
\text { studies and accept results without question. They do } \\
\text { make implications of practice based on the results of some } \\
\text { of this prior research. As a result, it is difficult to see if } \\
\text { the authors maintain objectivity. They do a good job of } \\
\text { paraphrasing and do not have an overreliance of quotes } \\
\text { from original sources. }\end{array}$ \\
\hline $\begin{array}{l}\text { 6. If the review is part of a research report for a new study, does } \\
\text { the review support the need for the study? }\end{array}$ & $\begin{array}{l}\text { The review is not part of a research report for a new } \\
\text { study. }\end{array}$ \\
\hline $\begin{array}{l}\text { 7. If it is a review designed to summarize evidence for clinical } \\
\text { practice, does the review draw reasonable conclusions about } \\
\text { practice implications? }\end{array}$ & $\begin{array}{l}\text { This review does draw reasonable conclusions about } \\
\text { anesthesia practice implications based on the literature } \\
\text { reviewed. Authors acknowledged that although IA is a } \\
\text { rare occurrence, it can have devastating effects. It is } \\
\text { important for anesthesia providers to perform a thorough } \\
\text { preoperative evaluation in order to determine if a patient } \\
\text { is at greater risk than normal for awareness. If the patient } \\
\text { is at higher risk, there is a series of steps and options that } \\
\text { the provider can utilize to decrease this potential, } \\
\text { including using BIS monitoring. }\end{array}$ \\
\hline
\end{tabular}




\section{Guidelines for Critiquing Literature Reviews}

Table C10

Castellon-Larios K., Rosero, B.R., Nino-de Mejia, M.C., \& Bergese, S.D. (2016). The use of cerebral monitoring for intraoperative awareness.Rev Colomb Anestesiol.;44:23-29.

\begin{tabular}{|l|l|}
\hline \multicolumn{1}{|c|}{ Critiquing Questions } & \multicolumn{1}{c|}{ Critique Responses } \\
\hline $\begin{array}{l}\text { 1. Is the review thorough-does it include all major studies on the } \\
\text { topic? Does it include recent research (studies published within } \\
\text { previous 2-3 years)? Are studies from other related disciplines } \\
\text { included, if appropriate? }\end{array}$ & $\begin{array}{l}\text { Review is fairly thorough. It includes randomized control } \\
\text { trials, systematic reviews, prospective studies, } \\
\text { retrospective studies, surveys, practice advisory, and } \\
\text { others. It does include recent research and other research } \\
\text { that is a little older, but nothing before 2001. The vast } \\
\text { majority of studies are from anesthesia journals and if not, } \\
\text { were appropriately included based on their content. }\end{array}$ \\
\hline $\begin{array}{l}\text { 2. Does the review rely mainly on primary source research } \\
\text { articles? Are the articles from peer-reviewed journals? }\end{array}$ & $\begin{array}{l}\text { For the most part, the review does primarily rely on } \\
\text { primary source research articles. The studies and results } \\
\text { that the authors use in their discussion are all primary } \\
\text { source articles. All the articles from journals are peer- } \\
\text { reviewed journals. }\end{array}$ \\
\hline $\begin{array}{l}\text { 3. Is the review merely a summary of existing work, or does it } \\
\text { critically appraise and compare key studies? Does the review } \\
\text { identify important gaps in the literature? }\end{array}$ & $\begin{array}{l}\text { Review is a summary of existing work. There is some } \\
\text { comparison made between similar studies, but not with } \\
\text { any new findings or revelations. It does try to summarize } \\
\text { potential causes of IA and methodology to try and prevent } \\
\text { it. The review does not identify any major gaps but does } \\
\text { acknowledge that more research needs to be done in this }\end{array}$ \\
\hline
\end{tabular}




\begin{tabular}{|c|c|}
\hline & area. \\
\hline $\begin{array}{l}\text { 4. Is the review well organized? Is the development of ideas } \\
\text { clear? }\end{array}$ & $\begin{array}{l}\text { The review is well organized in its structure. It defines IA } \\
\text { along with how memory is formed. It discusses the major } \\
\text { causes for possible IA as well as risk factors and } \\
\text { prevention strategies. The authors incorporate past } \\
\text { research to help reinforce their points as well as how they } \\
\text { came to certain conclusions. }\end{array}$ \\
\hline $\begin{array}{l}\text { 5. Does the review use appropriate language, suggesting the } \\
\text { tentativeness of prior findings? Is the review objective? Does } \\
\text { the author paraphrase, or is there an overreliance on quotes } \\
\text { from original sources? }\end{array}$ & $\begin{array}{l}\text { Review uses appropriate language in discussing past } \\
\text { research. Although it does not necessarily have a tentative } \\
\text { tone, the review does acknowledge some contradicting } \\
\text { results of past research. Review does seem to be } \\
\text { objective especially in how it came to conclusions. The } \\
\text { review did a good job of paraphrasing and only used a } \\
\text { direct quote once. }\end{array}$ \\
\hline $\begin{array}{l}\text { 6. If the review is part of a research report for a new study, does } \\
\text { the review support the need for the study? }\end{array}$ & N/A \\
\hline $\begin{array}{l}\text { 7. If it is a review designed to summarize evidence for clinical } \\
\text { practice, does the review draw reasonable conclusions about } \\
\text { practice implications? }\end{array}$ & $\begin{array}{l}\text { The review's conclusions definitely draw reasonable } \\
\text { conclusions from past research. The authors stated that } \\
\text { BIS does help the patient as an individual, along with } \\
\text { post-op outcomes and reduces complications. They stated } \\
\text { that it can help to maximize resources as a result. Finally, } \\
\text { they state that all patients should have an extensive pre- } \\
\text { anesthetic interview to determine if they have any relevant } \\
\text { risk factors or experiences that may make them }\end{array}$ \\
\hline
\end{tabular}




\begin{tabular}{|l|l|}
\hline & susceptible to IA. \\
\hline
\end{tabular}

*Reprinted with permission from the editor of D. Polit and C. Beck (2017). Nursing Research. Generating and assessing evidence for nursing practice $\left(10^{\text {th }}\right.$ ed.). Wolters Kluwer. 
Appendix D

Cross Analysis

\begin{tabular}{|l|l|l|l|l|}
\hline \multicolumn{1}{|c|}{ Author, } & \multicolumn{1}{|c|}{ Design } & BIS Monitoring & \multicolumn{1}{c|}{ IA } & \multicolumn{1}{c|}{ factors } \\
\hline $\begin{array}{l}\text { Ekman et al. } \\
(2004)\end{array}$ & $\begin{array}{l}\text { Prospective, } \\
\text { historical, } \\
\text { controlled } \\
\text { cohort trial at } 2 \\
\text { centers }\end{array}$ & $\begin{array}{l}\text { BIS group } \\
\text { versus no BIS } \\
\text { group }\end{array}$ & $\begin{array}{l}\text { Two episodes of IA in the } \\
\text { BIS group and 14 in the } \\
\text { historical control group } \\
\text { (statistically significant } \\
\text { value) }\end{array}$ & N/A \\
\hline $\begin{array}{l}\text { Avidan et al. } \\
(2008)\end{array}$ & $\begin{array}{l}\text { Pre- } \\
\text { randomized, } \\
\text { prospective } \\
\text { single-center } \\
\text { trial }\end{array}$ & $\begin{array}{l}\text { BIS group used } \\
\text { the BIS monitor } \\
\text { while the ETAG } \\
\text { used the end- } \\
\text { tidal anesthetic } \\
\text { gas }\end{array}$ & $\begin{array}{l}\text { group (no statistical } \\
\text { significance) }\end{array}$ & $\begin{array}{l}\text { High risk (at least 1 } \\
\text { major criteria or 2 minor } \\
\text { criteria)- Major criteria: } \\
\text { long-term use of } \\
\text { anticonvulsants, opiates, } \\
\text { benzodiazepines, or } \\
\text { cocaine; EF<40\%; } \\
\text { history of IA, difficult } \\
\text { intubation, or anticipated } \\
\text { difficult intubation; ASA } \\
\text { 4 or 5; aortic stenosis; } \\
\text { end-stage lung disease; } \\
\text { marginal exercise } \\
\text { tolerance not resulting } \\
\text { from musculoskeletal }\end{array}$ \\
\hline
\end{tabular}




\begin{tabular}{|c|c|c|c|c|}
\hline & & & & $\begin{array}{l}\text { dysfunction; pulmonary } \\
\text { hypertension; planned } \\
\text { open-heart surgery; daily } \\
\text { alcohol consumption; } \\
\text { Minor criteria: } \\
\text { preoperative use of beta- } \\
\text { blockers; COPD; } \\
\text { moderate exercise } \\
\text { tolerance not resulting } \\
\text { from musculoskeletal } \\
\text { dysfunction; smoking } 2 \\
\text { or more PPD; BMI>30 }\end{array}$ \\
\hline $\begin{array}{l}\text { Sebel et al. } \\
(2004)\end{array}$ & $\begin{array}{l}\text { Prospective, } \\
\text { nonrandomized } \\
\text { descriptive } \\
\text { cohort trial at } 7 \\
\text { centers }\end{array}$ & $\begin{array}{l}\text { BIS monitor use } \\
\text { was at the } \\
\text { discretion of the } \\
\text { attending } \\
\text { anesthesiologist; } \\
38 \% \text { of cases in } \\
\text { the trial utilized } \\
\text { the BIS }\end{array}$ & $\begin{array}{l}12 \text { episodes of awareness in } \\
\text { the non-BIS sample and } 13 \\
\text { episodes of awareness in } \\
\text { the BIS sample; } 26 \\
\text { episodes of possible } \\
\text { awareness in the non-BIS } \\
\text { sample and } 20 \text { episodes of } \\
\text { possible awareness in the } \\
\text { BIS sample (no significant } \\
\text { association) }\end{array}$ & N/A \\
\hline $\begin{array}{l}\text { Myles et al. } \\
\text { (2004) }\end{array}$ & $\begin{array}{l}\text { Prospective, } \\
\text { randomized, } \\
\text { double-blind } \\
\text { trial at } 21 \\
\text { centers }\end{array}$ & $\begin{array}{l}\text { BIS group used } \\
\text { the BIS monitor } \\
\text { while the } \\
\text { routine care } \\
\text { group did not }\end{array}$ & $\begin{array}{l}22 \text { cases of confirmed or } \\
\text { possible awareness in the } \\
\text { BIS group and } 27 \text { such } \\
\text { events in the routine care } \\
\text { group; this was an } 82 \% \\
\text { reduction in the risk of }\end{array}$ & $\begin{array}{l}\text { At least } 1 \text { risk factor: } \\
\text { high-risk cardiac surgery } \\
(\mathrm{EF}<30 \% \text {, cardiac index } \\
<2.1 \mathrm{~L} / \mathrm{min} / \mathrm{m}^{2} \text {, severe } \\
\text { aortic stenosis, } \\
\text { pulmonary hypertension, }\end{array}$ \\
\hline
\end{tabular}




\begin{tabular}{|c|c|c|c|c|}
\hline & & & awareness & $\begin{array}{l}\text { undergoing off-pump } \\
\text { CABG); acute trauma } \\
\text { with hypovolemia; rigid } \\
\text { bronchoscopy; } \\
\text { significant impairment } \\
\text { of cardiovascular status } \\
\text { and expected } \\
\text { intraoperative } \\
\text { hypotension requiring } \\
\text { treatment, severe end- } \\
\text { stage lung disease, past } \\
\text { history of IA, anticipated } \\
\text { difficult intubation } \\
\text { where an awake } \\
\text { intubation was not } \\
\text { planned; known or } \\
\text { suspected heavy alcohol } \\
\text { use; chronic } \\
\text { benzodiazepine or opioid } \\
\text { use; current protease } \\
\text { inhibitor therapy }\end{array}$ \\
\hline $\begin{array}{l}\text { Mashour et } \\
\text { al. (2012) }\end{array}$ & $\begin{array}{l}\text { Randomized } \\
\text { controlled trial } \\
\text { at } 3 \text { centers }\end{array}$ & $\begin{array}{l}\text { BIS group used } \\
\text { the BIS monitor } \\
\text { while the MAC } \\
\text { group used the } \\
\text { minimum } \\
\text { alveolar } \\
\text { concentration }\end{array}$ & $\begin{array}{l}11 \text { episodes of } \\
\text { intraoperative awareness in } \\
\text { the MAC group and } 8 \\
\text { episodes in the BIS group; } \\
\text { this was not statistically } \\
\text { significant }\end{array}$ & $\mathrm{N} / \mathrm{A}$ \\
\hline
\end{tabular}




\begin{tabular}{|c|c|c|c|c|}
\hline & & $\begin{array}{l}\text { (MAC) and end- } \\
\text { tidal anesthetic } \\
\text { level }\end{array}$ & & \\
\hline $\begin{array}{l}\text { Avidan et al. } \\
\text { (2011) }\end{array}$ & $\begin{array}{l}\text { Prospective, } \\
\text { randomized, } \\
\text { evaluator- } \\
\text { blinded trial at } \\
3 \text { centers }\end{array}$ & $\begin{array}{l}\text { BIS group used } \\
\text { the BIS monitor } \\
\text { while the ETAG } \\
\text { used the end- } \\
\text { tidal anesthetic } \\
\text { gas }\end{array}$ & $\begin{array}{l}\text { Seven cases of definite IA } \\
\text { in the BIS group and } 2 \text { in } \\
\text { the ETAG group (both of } \\
\text { these numbers were in the } \\
95 \% \text { confidence interval); } \\
19 \text { cases of definite or } \\
\text { possible IA in the BIS and } \\
8 \text { in the ETAG group }\end{array}$ & $\begin{array}{l}\text { At least } 1 \text { high risk } \\
\text { factor: planned open- } \\
\text { heart surgery; aortic } \\
\text { stenosis; pulmonary } \\
\text { hypertension; use of } \\
\text { opiates, } \\
\text { benzodiazepines, or } \\
\text { anticonvulsants; daily } \\
\text { alcohol use; ASA 4; end- } \\
\text { stage lung disease; } \\
\text { history of IA, difficult } \\
\text { intubation, or anticipated } \\
\text { difficult intubation; } \\
\text { EF }<40 \% \text {; marginal } \\
\text { exercise tolerance }\end{array}$ \\
\hline $\begin{array}{l}\text { Forman } \\
\text { (2006) }\end{array}$ & $\begin{array}{l}\text { Qualitative } \\
\text { study }\end{array}$ & $\begin{array}{l}\text { Some BIS } \\
\text { monitoring } \\
\text { studies are used } \\
\text { including } 2 \\
\text { which resulted } \\
\text { in an } 80 \% \\
\text { reduction in IA } \\
\text { while another } \\
\text { resulted in } \\
\text { higher rates of }\end{array}$ & $\begin{array}{l}\text { IA is investigated including } \\
\text { how it can differ in } \\
\text { patients, risk factors that } \\
\text { can cause it, and how } \\
\text { anesthetic drugs can impact } \\
\text { it; bias in awareness } \\
\text { monitor studies is discussed }\end{array}$ & $\begin{array}{l}\text { Reported risk factors: } \\
\text { use of muscle relaxers; } \\
\text { inadequate anesthesia; } \\
\text { cardiac surgery; trauma } \\
\text { surgery; C-section under } \\
\text { general anesthesia; } \\
\text { chronic alcohol, } \\
\text { anticonvulsant, opiate, or } \\
\text { sedative drug use; } \\
\text { history of IA; limited }\end{array}$ \\
\hline
\end{tabular}




\begin{tabular}{|c|c|c|c|c|}
\hline & & $\begin{array}{l}\text { IA using a BIS } \\
\text { than without it }\end{array}$ & & $\begin{array}{l}\text { cardiovascular reserve; } \\
\text { ASA } 4 \text { or } 5\end{array}$ \\
\hline $\begin{array}{l}\text { Apfelbaum } \\
\text { et al. (2006) }\end{array}$ & $\begin{array}{l}\text { Using surveys, } \\
\text { journal articles, } \\
\text { and open } \\
\text { forums, the } \\
\text { advisory } \\
\text { members } \\
\text { produced a } \\
\text { written } \\
\text { advisory on } \\
\text { interventions } \\
\text { to help prevent } \\
\text { IA }\end{array}$ & $\begin{array}{l}\text { The advisory } \\
\text { stated that brain } \\
\text { monitoring (like } \\
\text { the BIS) are not } \\
\text { routinely } \\
\text { indicated for } \\
\text { patients } \\
\text { undergoing } \\
\text { general } \\
\text { anesthesia; their } \\
\text { opinion was that } \\
\text { the use of brain } \\
\text { function } \\
\text { monitoring } \\
\text { should be made } \\
\text { on a case-by- } \\
\text { case basis } \\
\text { depending on } \\
\text { risk factors and } \\
\text { anesthesia goals }\end{array}$ & $\begin{array}{l}\text { The advisory produced a } \\
\text { list of recommendations } \\
\text { that are suggested to be } \\
\text { used proactively to try and } \\
\text { prevent IA. Some of the } \\
\text { criteria include a thorough } \\
\text { preop assessment, ensuring } \\
\text { all mechanical } \\
\text { equipment/devices are } \\
\text { functioning properly, and } \\
\text { intraoperative/postoperative } \\
\text { strategies }\end{array}$ & $\begin{array}{l}\text { Potential risk factors: } \\
\text { substance use; history of } \\
\text { IA, difficult intubation, } \\
\text { or anticipated difficult } \\
\text { intubation; chronic paint } \\
\text { patients using high doses } \\
\text { of opioids; ASA } 4 \text { or 5; } \\
\text { limited hemodynamic } \\
\text { reserve; cardiac surgery; } \\
\text { C-section; trauma or } \\
\text { emergency surgery; } \\
\text { reduced anesthetic doses } \\
\text { in the presence of } \\
\text { paralysis; planned usage } \\
\text { of muscle relaxants } \\
\text { during maintenance of } \\
\text { general anesthesia; } \\
\text { planned use of nitrous } \\
\text { oxide-opioid anesthesia }\end{array}$ \\
\hline $\begin{array}{l}\text { Kotsovolis } \\
\& \\
\text { Komninos } \\
(2009)\end{array}$ & Review article & $\begin{array}{l}\text { The study } \\
\text { proclaims that } \\
\text { the BIS monitor } \\
\text { is the only } \\
\text { reliable } \\
\text { anesthesia depth }\end{array}$ & $\begin{array}{l}\text { The authors acknowledge } \\
\text { that IA can have deleterious } \\
\text { ramifications and that } \\
\text { prevention is the best } \\
\text { strategy; they suggest a } \\
\text { thorough preop evaluation, }\end{array}$ & $\begin{array}{l}\text { Reported risk factors: } \\
\text { insufficient drug } \\
\text { administration for } \\
\text { cardiothoracic, trauma, } \\
\text { emergency, C-section } \\
\text { surgeries, and ASA } 4 \text { or }\end{array}$ \\
\hline
\end{tabular}




\begin{tabular}{|c|c|c|c|c|}
\hline & & $\begin{array}{l}\text { monitor as a } \\
\text { result of a few } \\
\text { studies and a } \\
\text { meta-analysis; } \\
\text { however, the } \\
\text { authors also } \\
\text { state that its use } \\
\text { must be limited } \\
\text { to high-risk } \\
\text { patients and that } \\
\text { that although it } \\
\text { can decrease } \\
\text { cases of } \\
\text { awareness, the } \\
\text { cost does not } \\
\text { allow for usage } \\
\text { in all cases }\end{array}$ & $\begin{array}{l}\text { identification of high-risk } \\
\text { patients along with a } \\
\text { discussion of possible IA } \\
\text { for them, anesthesia } \\
\text { machine checking along } \\
\text { with devices to be used, } \\
\text { and an individualized } \\
\text { anesthetic plan }\end{array}$ & $\begin{array}{l}5 \text { patients; chronic use of } \\
\text { benzodiazepines or } \\
\text { opioids; alcoholics; } \\
\text { severely anxious } \\
\text { patients; difficult airway; } \\
\text { previous IA experience; } \\
\text { anesthesia machine } \\
\text { malfunction (disorder or } \\
\text { incomplete check) }\end{array}$ \\
\hline $\begin{array}{l}\text { Castellon- } \\
\text { Larios et al., } \\
\text { (2016) }\end{array}$ & Review & $\begin{array}{l}\text { The authors } \\
\text { reviewed } \\
\text { several studies } \\
\text { which utilized } \\
\text { BIS in the } \\
\text { prevention of } \\
\text { IA; one study } \\
\text { resulted in a } \\
65.4 \% \text { reduction } \\
\text { in IA compared } \\
\text { to standard }\end{array}$ & $\begin{array}{l}\text { IA is thoroughly discussed } \\
\text { starting with a definition } \\
\text { (“experience and specific } \\
\text { memory of a sensory } \\
\text { perception during } \\
\text { surgery”), proceeding to } \\
\text { causes and risk factors, } \\
\text { how to diagnose it, and } \\
\text { finally, prevention } \\
\text { strategies }\end{array}$ & $\begin{array}{l}\text { Reported risk factors: } \\
\text { error or fault in } \\
\text { anesthesia } \\
\text { administration- human } \\
\text { error; equipment or } \\
\text { usage error; difficult } \\
\text { intubation; hypovolemia; } \\
\text { type of surgery (heart, } \\
\text { trauma, obstetric) } \\
\text { Use of neuromuscular } \\
\text { blockers- }\end{array}$ \\
\hline
\end{tabular}




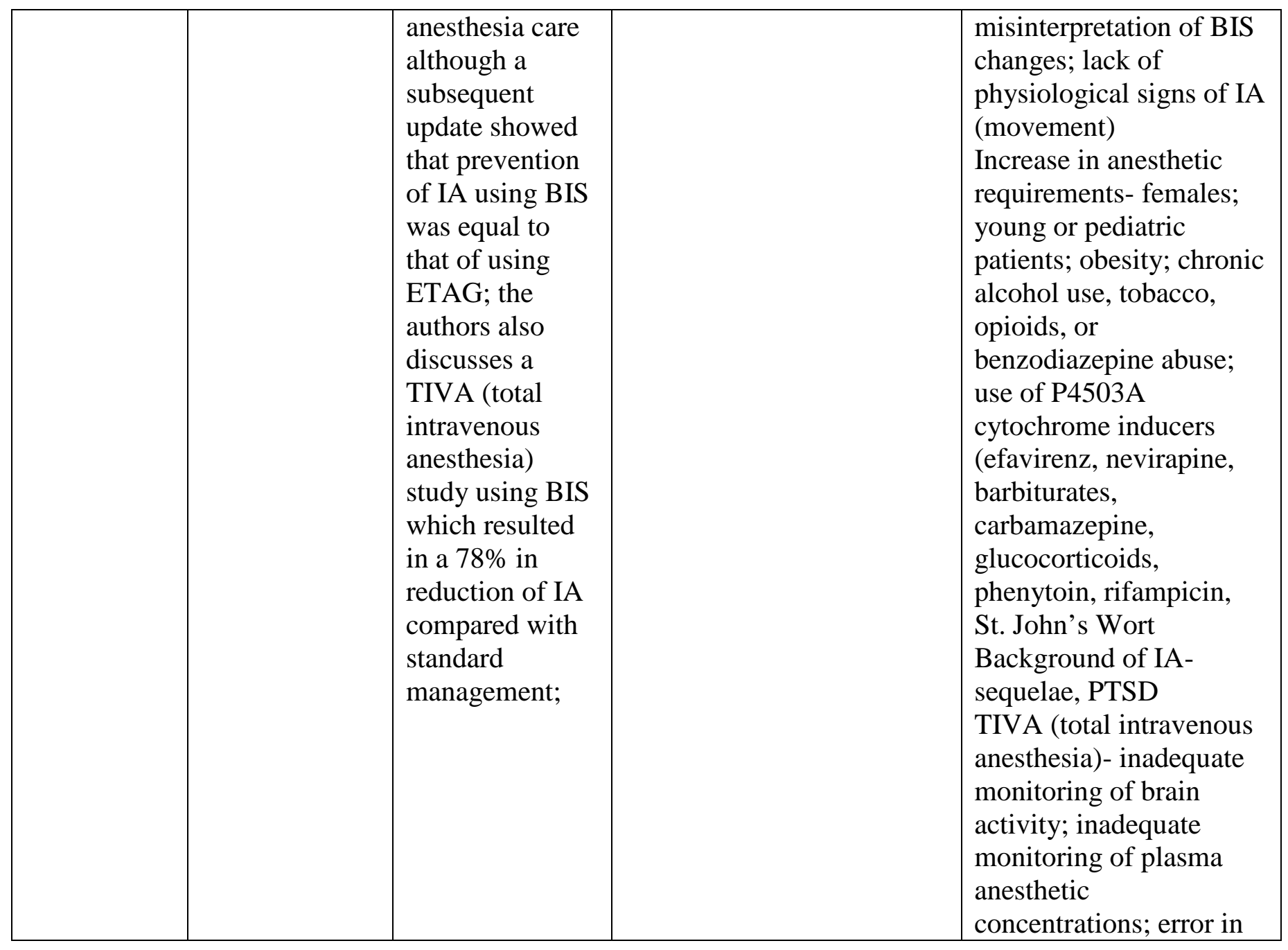




\begin{tabular}{|l|l|l|l|l|}
\hline & & & $\begin{array}{l}\text { anesthetic } \\
\text { administration; blockage } \\
\text { or leaking in venous } \\
\text { access }\end{array}$ \\
\hline
\end{tabular}

